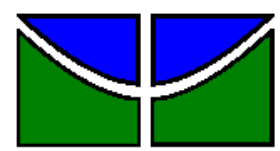

UNIVERSIDADE DE BRASÍLIA

FACULDADE DE EDUCAÇÃO

PROGRAMA DE PÓS-GRADUAÇÃO EM EDUCAÇÃO

POLYANA GONÇALVES DE SOUSA

AS INTERFACES ENTRE A TERAPIA OCUPACIONAL E A TEORIA DA SUBJETIVIDADE NOS PROCESSOS DE APRENDIZAGEM

BRASÍLIA-DF

2017 
POLYANA GONÇALVES DE SOUSA

AS INTERFACES ENTRE A TERAPIA OCUPACIONAL E A TEORIA DA SUBJETIVIDADE NOS PROCESSOS DE APRENDIZAGEM

Dissertação apresentada ao Programa de PósGraduação da Faculdade de Educação, da Universidade de Brasília, como parte dos requisitos para a obtenção do título de Mestre em Educação, na Linha de Pesquisa Escola, Aprendizagem, Ação Pedagógica e Subjetividade na Educação.

Orientadora: Prof. ${ }^{a}$ Dr. ${ }^{a}$ Maria Carmen Villela Rosa Tacca

BRASÍLIA - DF 


\title{
AS INTERFACES ENTRE A TERAPIA OCUPACIONAL E A TEORIA DA SUBJETIVIDADE NOS PROCESSOS DE APRENDIZAGEM
}

\author{
Dissertação apresentada ao Programa de Pós- \\ Graduação da Faculdade de Educação, da \\ Universidade de Brasília, como parte dos requisitos \\ para a obtenção do título de Mestre em Educação, na \\ Linha de Pesquisa Escola, Aprendizagem, Ação \\ Pedagógica e Subjetividade na Educação.
}

\section{Banca Examinadora:}

Profa. Dra. Maria Carmem Villela Rosa Tacca - Presidente Faculdade de Educação - UnB

Prof. Dr. Fernando Luís González Rey - Membro interno Faculdade de Educação - UnB

Profa. Dra. Alexandra Ayach Anache - Membro externo Departamento de Ciências Humanas- UFMS

Profa. Dra. Cristina Massot Madeira Coelho - Suplente Faculdade de Educação - UnB 
Dedico este trabalho à minha família, em especial, à minha avó Almerinda e ao meu tio José Roberto (in memorian), que sempre acreditaram em mim, apoiaram e incentivaram-me na busca pelo conhecimento. Sei que de onde estiverem, estão muito felizes, esta conquista também é deles. 


\section{AGRADECIMENTOS}

Agradeço a Deus, autor da minha vida e da minha história, por permitir-me ter vivenciado e concluindo mais essa etapa da minha vida, por ter me capacitado, e concedido força e sabedoria nos momentos de dificuldade.

Aos meus pais, Cláudia e Fábio, e irmãos, Tiago e Raquel, que com muita paciência, amor e humildade me ensinaram a importância de acreditar em mim mesma e a persistir no caminho da aprendizagem, mesmo nos momentos de dificuldades. A paciência, o carinho, a atenção e o apoio de vocês foram essenciais para a conclusão de mais essa etapa em minha vida.

Ao meu namorado e amigo, Matheus, por todo apoio, paciência e compreensão durante essa etapa. Por estar sempre ao meu lado, me incentivando em minhas conquistas e realizações.

À minha orientadora Maria Carmen Tacca, por ter me permitido vivenciar momentos de grande aprendizagem e crescimento profissional e pessoal. Agradeço por ter compartilhado um pouco de sua grande sabedoria, e por toda dedicação e acolhimento nos pequenos gestos, que possibilitaram momentos especiais nessa jornada acadêmica.

Aos colegas de aprendizagem que conheci durante esse percurso, em especial, à Maria do Socorro, Kátia, Elisângela, Oneida, Caroline, Diego e Renata, agradeço pelo acolhimento e pela troca de experiências durante os grupos de estudos, foram momentos de grande alegria e de importante aprendizagem teórica.

Aos professores da banca pela disponibilidade e atenção em aceitar participar desse momento. É uma honra ter a contribuição de vocês nesse trabalho, representando um grande aprendizado e enriquecimento para a minha formação profissional.

Aos responsáveis pelo curso de extensão "Novas tendências na psicoterapia: para além da clínica tradicional", em especial os palestrantes, por terem compartilhado seus conhecimentos e experiências, contribuindo de forma significativa para importantes avanços teóricos desenvolvidos nesse trabalho.

Aos professores que participaram de minha jornada acadêmica, desde a época da escola, da faculdade, até o mestrado acadêmico, que ao compartilharem um pouco de seus conhecimentos contribuíram para a minha formação acadêmica e para a conclusão dessa etapa. Em especial, ao professor González Rey, o qual os trabalhos me inspiraram a ingressar no mestrado.

Às profissionais que participaram da pesquisa, a terapeuta ocupacional e as professoras, pela disponibilidade e atenção em relação ao trabalho, me permitindo aprender com suas práticas e reflexões, gerando contribuições para a minha formação profissional.

Aos adolescentes que participaram da pesquisa, por terem confiado em mim e nesse trabalho, por me permitirem conhecer um pouco de suas histórias e experiências, me fazendo perceber a capacidade de mudança inerente a cada pessoa, independente das dificuldades. 
“Desistir... eu já pensei seriamente nisso, mas nunca me levei realmente a sério; é que tem mais chão nos meus olhos do que o cansaço nas minhas pernas, mais esperança nos meus passos do que tristeza nos meus ombros, mais estrada no meu coração do que medo na minha cabeça”.

(Cora Coralina) 


\section{RESUMO}

Esse trabalho retrata as implicações da Teoria da Subjetividade de González Rey para a prática da Terapia Ocupacional (TO) no contexto educacional, a partir da compreensão dos aspectos subjetivos dos alunos que enfrentam situações de dificuldades de aprendizagem. Dessa forma, buscamos analisar a atuação da TO nesse âmbito, algumas questões do espaço escolar, além de compreender histórias e experiências de adolescentes em situações de dificuldade de aprendizagem. Para, assim, identificar possíveis contribuições da profissão, com base nos pressupostos da Teoria da Subjetividade, no contexto da aprendizagem. Esta pesquisa tem como referencial metodológico a Epistemologia Qualitativa de González Rey (2002, 2005a, 2005b), assim as informações foram analisadas a partir de um processo construtivo interpretativo. O campo empírico ocorreu em dois contextos: um espaço terapêutico da TO pertencente à Secretaria de Saúde do DF, no qual foi observado um grupo para adolescentes com TDAH (Transtorno do Déficit de Atenção e Hiperatividade); e uma escola de ensino fundamental da rede pública de ensino, frequentada por todos os participantes do grupo. A partir desses ambientes, os colaboradores da pesquisa foram: uma terapeuta ocupacional, duas professoras e os adolescentes participantes das sessões grupais, dos quais três foram escolhidos ao longo da pesquisa para realização de estudos de casos. As relações observadas entre os contextos e atuações profissionais, assim como a compreensão da dinâmica subjetiva dos adolescentes observada nos estudos de casos, permitiu-nos refletir sobre a existência do transtorno orgânico e suas implicações nas dificuldades de aprendizagem. Percebemos que as principais barreiras no contexto da aprendizagem e desenvolvimento implicavam aspectos do contexto e história de vida dos adolescentes, assim como relações sociais estabelecidas e a construção de ambientes favoráveis para que eles pudessem se posicionar. Observamos que a principal contribuição da prática em TO ocorreu a partir da concretização de um espaço que possibilitou a participação e comunicação dos adolescentes. No contexto escolar, percebemos as implicações das relações sociais e dos espaços de comunicação estabelecidos entre professor-aluno no processo de aprendizagem. Dessa forma, refletimos que os comportamentos expressos pelos alunos estavam além de uma relação direta com as características orgânicas do transtorno, mas indicavam a manifestação de uma dinâmica subjetiva complexa, com implicações de diversas questões sociais e familiares, demonstrando uma necessidade de espaços e relações sociais favoráveis para que eles pudessem se posicionar. Portanto, consideramos que as principais ações da TO, com base na Teoria da Subjetividade, consistem em promover ambientes que valorizem a emergência do sujeito, a partir de ações e instrumentos que estimulem processos de desenvolvimento subjetivo, tendo as relações sociais um destaque nesse processo. A relevância dessa pesquisa foi a possibilidade de contribuir para a formação em TO, principalmente em relação ao contexto escolar, a partir de articulações entre campos teórico-práticos ainda não explorados, conforme os pressupostos da Teoria da Subjetividade.

Palavras-chave: Terapia Ocupacional; Teoria da Subjetividade, dificuldades de aprendizagem. 


\begin{abstract}
This work depicts about the implications of the theory of the subjectivity of González Rey for the practice of occupational therapy (OT) in the educational context, based on the understanding of the subjective aspects of students who face situations of learning difficulties. In this way, we seek to analyze the performance of to in this context; some issues of school space, as well as understand stories and experiences of adolescents in situations of learning difficulties. So, identify possible contributions of the profession, based on the assumptions of the theory of subjectivity, to the context of learning. This research has as methodological Epistemology of González Rey (2002, 2005a, 2005b), so the information was analyzed from a constructive process. The Empirical field occurred in two contexts: a space of OT belonging to the Department of Health of the DF, which was an observed group for adolescents with ADHD (Attention Deficit Hyperactivity Disorder); and in a primary school of public education, attended by all the members of the group. From these environments, employees of the research were: an occupational therapist, two teachers and young participants of group sessions, three of which were chosen throughout the research to conduct case studies. The relationship observed between the contexts and professional performances, as well as the understanding of the dynamics of subjective adolescents of case studies allowed us to reflect on the existence of an organic disorder and its implications in learning difficulties. We realized that the main barriers in the context of learning and development were concerned with aspects of the context and history of life of adolescents, as well as in social relations established and in the construction of favorable environments so they could position themselves. We observed that the main contribution of the practice OT occurs from the implementation of a space that allowed the participation and communication of adolescents. In the school context we realize the implications of social relations and the spaces of communication established between teacher-student in the learning process. In this way, we reflected that the behaviors expressed by students, were beyond a direct relationship with the characteristics of organic disorder, but indicated the manifestation of a subjective dynamic complex, with implications of various social issues and family, demonstrating a need for spaces and social relations conducive so that they could be positioned. Therefore, we consider that the main actions of OT, based on the theory of subjectivity, are to promote environments that enhance the emergence of the subject, from actions and instruments that stimulate the development processes subjective, having the social relations a highlight in this process. The relevance of this research was to contribute to the formation at OT, especially in relation to the school context, from joints between fields theoretical-practical not yet explored, as the assumptions of the Theory of Subjectivity.
\end{abstract}

Keywords: Occupational Therapy; Theory of Subjectivity, learning difficulties. 


\section{SUMÁRIO}

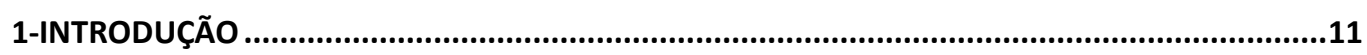

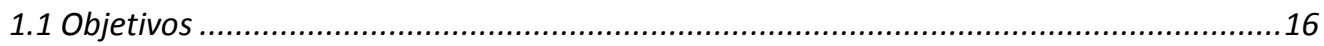

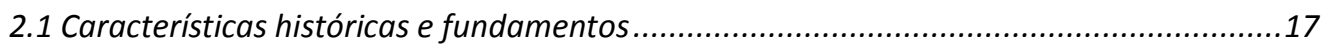

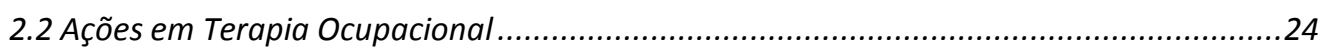

2.3 Modelos teóricos práticos em Terapia Ocupacional ......................................................30

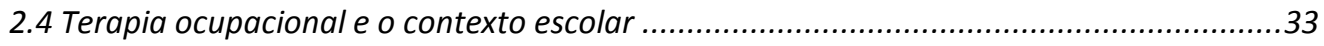

3-TEORIA DA SUBJETIVIDADE E TERAPIA OCUPACIONAL .......................................................45

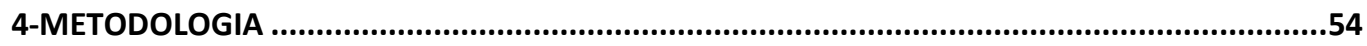

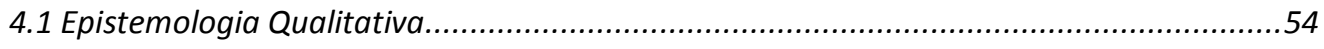

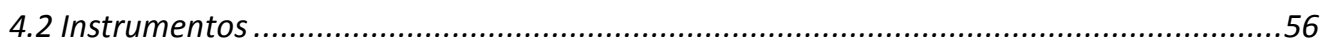

4.3 Locais da pesquisa e construção do cenário de pesquisa ...........................................58

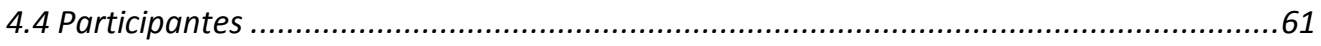

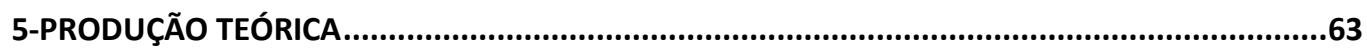

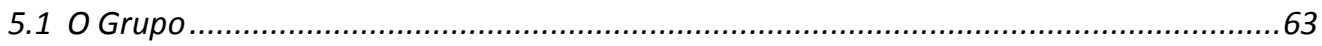

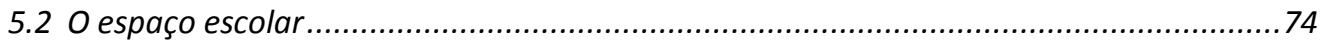

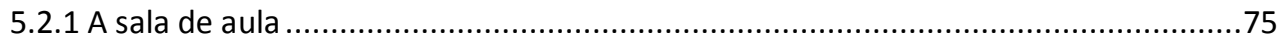

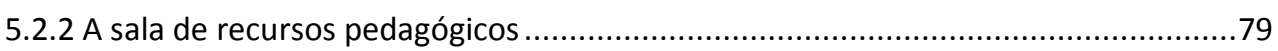

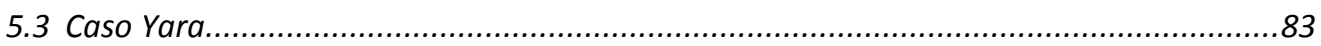

5.3.1 Caracterização e construção do cenário de pesquisa...........................................83

5.3.2. A subjetivação do rótulo de TDAH e a dinâmica subjetiva ....................................85

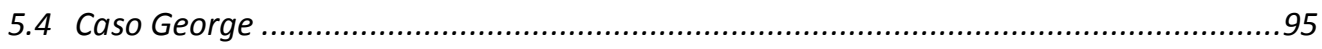

5.4.1 Caracterização e construção do cenário de pesquisa..........................................95

5.4.2 A subjetivação do rótulo de TDAH e a dinâmica subjetiva ....................................97

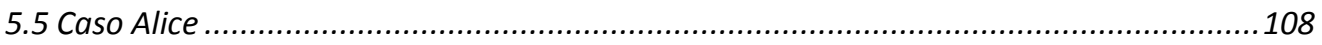

5.5.1 Caracterização e construção do cenário de pesquisa..........................................108

5.5.2 A subjetivação do rótulo de TDAH e a dinâmica subjetiva ...................................110 
6-ANÁLISE INTEGRATIVA DOS CASOS E CONTEXTOS E POSSIBILIDADES DE CONTRIBUIÇÕES DA

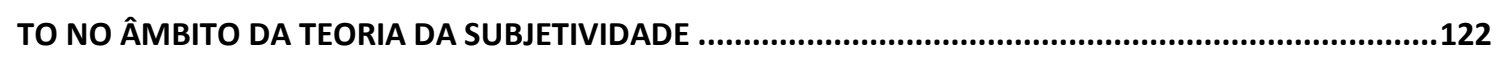

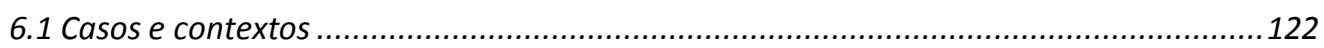

6.2 Articulações entre a Teoria da Subjetividade e a Terapia Ocupacional .........................131

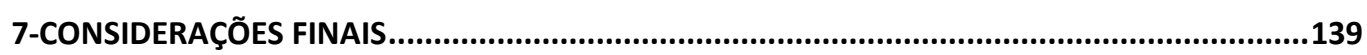

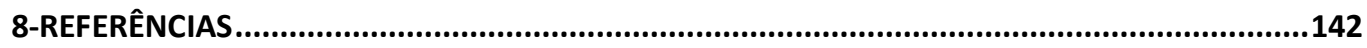

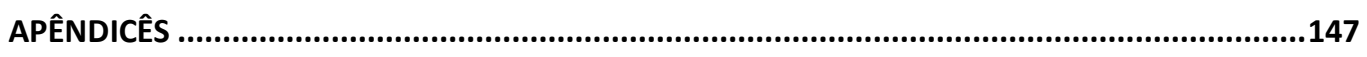

APÊNDICE A- COMPLEMENTO DE FRASE ...............................................................147

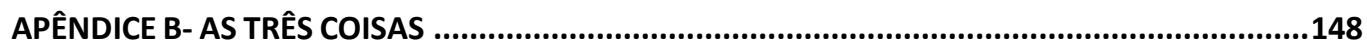

APÊNDICE C- DESENHO “O MUNDO IDEAL”- GEORGE ........................................................150

APÊNDICE D- DESENHO “O MUNDO IDEAL”- ALICE ......................................................151

APÊNDICE E- TERMO DE CONSENTIMENTO LIVRE ESCLARECIDO(TCLE) ..............................152 


\section{1-INTRODUÇÃO}

Uma criança com dificuldades no processo de aprendizagem sempre gera grandes repercussões sobre suas possibilidades e formas de desenvolvimento diante desse contexto. Tal situação acarreta muitas ansiedades, aparecendo a necessidade de caracterizar a origem dessas dificuldades. Na maioria das vezes, priorizam-se estratégias mais rápidas e pontuais a fim de identificar o "problema" e encontrar a solução. Dessa forma, o diagnóstico toma a dianteira do processo. Na minha atuação como Terapeuta Ocupacional, percebi a importância dada a essa questão nos processos de aprendizagem. A supervalorização do diagnóstico, observada tanto por parte família como pela equipe educacional, exigia um laudo médico para realizar o correto atendimento pedagógico com a criança. Porém, ao ser oficializado um diagnóstico, geralmente a responsabilização das dificuldades no processo de aprendizagem recaíam exclusivamente sobre essa questão. Assim, se a criança fazia algo de errado, como fugir da escola, ficar com raiva, chorar, não querer falar, desrespeitar o professor ou simplesmente quando não conseguia aprender algo, a culpa era de suas características. Na prática em Terapia Ocupacional, dificilmente se dá grande ênfase na realização de um diagnóstico, visto que esse profissional não tem como uma de suas competências realizar essa ação. Dessa forma, essas questões são decorrentes da prática médica ou psicológica e na forma com que elas refletem na família e no contexto pedagógico. Portanto, o diagnóstico aparece no processo em Terapia Ocupacional principalmente pela ênfase com que surge no discurso da família e da equipe pedagógica.

E assim, observei a excessiva valorização dada ao diagnóstico, que muitas vezes era capaz de definir o que a criança era ou não capaz de fazer, sem considerar diversas outras questões que poderiam estar relacionadas ao seu desenvolvimento e aprendizagem. Nesse sentido, tanto na área terapêutica como na área escolar, observam-se métodos e práticas padronizadas para lidar com todas as pessoas igualmente, principalmente a partir dos rótulos que elas carregam, sem considerar a existência da singularidade por trás dos procedimentos usuais. O aluno escapa aos olhos, não sendo reconhecido como um ser que possui histórias, vivências, relações, capaz de produzir diversos sentidos e com vontades singulares. Portanto, a área da saúde, a escola, assim como a família, muitas vezes, não conseguem olhar essa criança além do diagnóstico, ou seja, como um sujeito por traz desses rótulos. Com isso, são adotadas práticas e relacionamentos despersonalizados e 
direcionados pela prática padronizada que desconsidera a complexidade que envolve o processo de desenvolvimento e aprendizagem de qualquer pessoa.

A articulação entre a área da saúde e da educação muito tem contribuído no contexto escolar, porém, algumas vezes nota-se a supervalorização dada aos procedimentos terapêuticos, principalmente por parte dos encaminhamentos da escola aos serviços de saúde. Assim, a maioria das práticas escolares, no contex to da inclusão, acaba se restringindo aos medicamentos, técnicas e procedimentos tradicionais de acordo com cada diagnóstico. Desconsidera-se que mesmo existindo dois sujeitos com uma mesma patologia, a forma como eles se relacionam com a aprendizagem é singular e, dessa forma, as abordagens terapêuticas e educacionais, com cada um, também deveriam ser diferenciadas.

Acredita-se que muito dessa padronização de métodos e técnicas tenha sua origem nos procedimentos terapêuticos, que refletem na área educacional, a partir das ações padronizadas passadas pelos profissionais da saúde aos profissionais da educação. E estes, muitas vezes, reproduzem em sala de aula procedimentos mecanizados de forma a não considerar outros fatores envolvidos na aprendizagem, não sabendo como lidar com as especificidades desses alunos, o que gera estereótipos e ações equivocadas sobre eles. Tanto os profissionais da saúde como os da educação frequentemente atribuem o "não aprender" às características do diagnóstico, sem considerar outros fatores contextuais e pessoais envolvidos. Essa situação produz diferentes rótulos e esses profissionais acabam limitando sua atuação através de práticas generalizadas e despersonalizadas, subestimando as capacidades de aprendizado de cada sujeito que aprende. Essa conduta muitas vezes se reflete em práticas excludentes. A área da saúde, a escola e a família acabam se eximindo da responsabilidade de investimento nas diferentes possibilidades existentes no processo de aprendizagem dos alunos com dificuldades de aprendizagem, ficando esses estudantes, muitas vezes, excluídos socialmente.

Segundo Antunes (2008), muitas vezes o problema não é a patologia, e sim em como se trabalhar com esses alunos, para ajudá-los a pensar e a aprender. Conforme citação do autor, é necessário promover mudanças nos procedimentos terapêuticos e pedagógicos, a partir de ações que permitam ir além do diagnóstico, ou seja, voltadas para a compreensão da singularidade de cada aluno no processo de aprender. 
Tacca e González Rey (2008) destacam que o professor, ao focar sua atenção nos processos subjetivos e de produção de sentido dos alunos, poderia identificar as necessidades que permeiam esses sujeitos, para que assim, pudessem ser pensadas em estratégias diferentes para a aprendizagem de cada um. Com isso, a partir da compreensão dos aspectos subjetivos que participam da aprendizagem, os rótulos estereotipados que são concedidos às pessoas, muitas vezes de forma equivocada, poderiam ser esclarecidos e até mesmo desconsiderados. Essa questão também se articula ao contexto de saúde, pois ao se conhecer os aspectos subjetivos compreendidos na relação terapêutica, assim como suas implicações nesse contexto e em outros, poderiam ser identificados melhores estratégias e procedimentos terapêuticos para se lidar de forma singular com cada sujeito. Destaca Sá (2009, p. 656) que “a especificidade do trabalho em saúde, ou o que constitui sua essência, é sua característica intersubjetiva e de intervenção única de um sujeito sobre outro, em suas experiências singulares de vida, prazer, dor, sofrimento e morte." Dessa forma, faz-se necessário compreender e identificar, na área da saúde, e mais especificamente na prática da Terapia Ocupacional, procedimentos e ações que valorizem aspectos subjetivos dos alunos em situações de dificuldade de aprendizagem, a fim de se repensar práticas terapêuticas com vistas a promover contribuições para o contexto escolar.

A Terapia Ocupacional (TO) é uma das profissões que realiza a interface entre as áreas da saúde e educação. O seu objetivo principal é promover a independência e autonomia das pessoas na realização de suas diversas atividades do dia a dia e em diferentes ambientes de participação. Segundo a definição do CREFITO 11 (Conselho Regional de Fisioterapia e Terapia Ocupacional). A Terapia Ocupacional é:

\footnotetext{
"uma área do conhecimento voltada aos estudos, à prevenção e ao tratamento de indivíduos portadores de alterações cognitivas, afetivas, perceptivas e psicomotoras, decorrentes ou não de distúrbios genéticos, traumáticos e/ou de doenças adquiridas, através da sistematização e utilização da atividade humana como base de desenvolvimento de projetos terapêuticos específicos."
}

A profissão utiliza a atividade humana como recurso terapêutico, com o objetivo de desenvolver, prevenir e/ou restaurar habilidades e capacidades que foram afetadas em decorrências de dificuldades físicas, motoras, psíquicas e sociais, e que interfiram na 
autonomia do sujeito e na realização de suas atividades cotidianas. Portanto, o terapeuta procura criar condições para que as pessoas realizem de forma mais autônoma possível suas ocupações diárias, que constituem o cotidiano singular de cada sujeito.

Na infância/adolescência, um dos principais contextos de participação social é a escola, sendo esta uma das suas principais ocupações. Ao ocorrer alguma interferência que impeça ou dificulte a participação dos sujeitos dentro desse espaço, este passa a ser um campo de atuação da Terapia Ocupacional, a fim de promover a participação de forma mais autônoma possível desses indivíduos no contexto escolar. Para isso, realizam-se intervenções coletivas com os educadores, alunos, pais e comunidade e, no âmbito individual, com o aluno. A partir de ações de discussão e reflexão, promove-se formação de grupos coletivos, a fim de facilitar o aparecimento das dificuldades que permeiam a inclusão, promovendo debates e esclarecimentos sobre o sentido que determinada deficiência adquire nesse contexto. Também são realizadas modificações no ambiente, através de adaptações no espaço físico, no mobiliário e instrumentos pedagógicos, fazendo-se a eliminação de barreiras arquitetônicas. No âmbito individual, as intervenções ocorrem através da elaboração de um plano terapêutico de acordo com as demandas de cada sujeito, a fim de facilitar a autonomia e participação na realização das atividades no contexto escolar. Para isso, utilizam-se diversos recursos terapêuticos que, muitas vezes, têm a finalidade de reabilitar funções ou promover adaptações, para que o indivíduo possa participar da melhor maneira possível das atividades propostas. Nesse contexto, tem-se, por exemplo, o uso de tecnologias assistivas e a realização de atividades para atingir os objetivos terapêuticos.

As tecnologias assistivas (TA) envolvem as comunicações alternativas e ampliadas, recursos para acesso ao computador, próteses, mobilidade alternativa, adaptações de postura, entre outros, sendo usados em diferentes contextos, como na escola, em casa, no lazer ou no trabalho. A utilização desses recursos na TO requer uma análise das necessidades dos usuários e suas habilidades necessárias para esse uso. Além disso, o terapeuta precisa avaliar a receptividade do sujeito em relação a essa adaptação e modificação, assim como a relação com a condição sociocultural e as características físicas do ambiente (PELOSI, 2005). Portanto, essas tecnologias são recursos que contribuem para ampliar as habilidades funcionais do indivíduo, aumentando sua autonomia e independência em seus diferentes contextos e atividades. 
A maioria das ações em TO no contexto escolar, muitas vezes, está relacionada com as deficiências, sejam elas físicas, motoras ou sensoriais, o que concede uma ênfase para procedimentos e instrumentos padronizados, como por exemplo, os recursos de tecnologia assistiva, assim como para as atividades terapêuticas pré-estabelecidas com objetivo de restabelecer funções. Dessa forma, acaba-se desconsiderando ou menosprezando aspectos relacionados à singularidade do sujeito, que se entrelaçam com o seu contexto e história. Às vezes, essas técnicas e métodos padrões tornam-se tão tradicionais que acabam perdendo o sujeito atendido por elas. Além disso, a profissão de Terapia Ocupacional também pode contribuir com intervenções não somente relacionadas à deficiência, mas também em relação às dificuldades de aprendizagem que surgem nesse contexto. Levando-se em consideração esses aspectos, surgem, portanto, reflexões e questionamentos sobre o processo terapêutico na TO, tais como: todas as tecnologias assistivas, ou materiais, ou recursos técnicos podem ser aplicados a todos os pacientes que possuem a mesma limitação, sem considerar seu contexto, suas vontades e histórias? Ou ao se promover a atividade terapêutica, como meio para alcance do objetivo proposto, ela tem sentido para o paciente? O que o motiva a realizá-las, e como fazer isso? Ou ao se realizar alguma intervenção terapêutica, como uma órtese/prótese, qual o sentido que ela adquire para o aluno no contexto escolar? Além disso, o quanto ou como ele se reconhece como uma pessoa com dificuldade de aprendizagem? E como essa questão interfere no seu cotidiano, na sua vida escolar? Dessa forma, como a Terapia ocupacional poderia contribuir para os processos educacionais, além dos métodos e técnicas padrões?

Percebe-se, pois, a necessidade em aprofundar as questões subjetivas e o aparecimento do sujeito no processo terapêutico em TO, estando além dos procedimentos e ações padrões. Por exemplo, o principal recurso de intervenção da profissão, a atividade, ao ser utilizado, faz-se necessário olhar para além de suas implicações terapêuticas, mas para quem as realiza, visto que, as motivações não estão nas atividades, mas sim nos sujeitos (GONZÁLEZ REY, 2012).

Nesse sentido, este trabalho se torna relevante para a área educacional e terapêutica. Têm- se a necessidade de ampliação das ações em TO nesse contexto, tendo em vista o déficit de pesquisas nesse campo, e uma possível reflexão sobre as práticas e procedimentos existentes nesse âmbito, em relação à valorização do sujeito no processo terapêutico em detrimento do diagnóstico. Além disso, o trabalho possibilita a inovação em relação ao campo teórico-prático, pois propõe a articulação entre a prática da Terapia 
Ocupacional e os fundamentos da Teoria da Subjetividade de Gonzaléz Rey, representando contribuições aos processos de aprendizagem, que é o foco deste estudo.

\subsection{Objetivos}

Objetivo geral: Identificar implicações da Teoria da Subjetividade para a prática da Terapia Ocupacional tendo em vista os aspectos subjetivos dos sujeitos que enfrentam situações de dificuldades de aprendizagem.

\section{Objetivos específicos:}

- Analisar um processo terapêutico em Terapia Ocupacional a fim de compreender se os procedimentos e ações favorecem o aparecimento do sujeito, e como se lida com isso.

- Analisar aspectos relacionais e pedagógicos entre professor-aluno no contexto escolar, a fim de identificar contribuições da TO para o enfrentamento das dificuldades de aprendizagem, com base na Teoria da Subjetividade.

- Compreender a configuração subjetiva de alunos diagnosticados com TDAH, para além dos rótulos e comportamentos, a partir da análise de questões relacionadas à história de vida, contextos e cotidiano desses estudantes.

- Identificar possíveis contribuições interventivas da Terapia Ocupacional para os processos de aprendizagem, a partir dos casos e contextos analisados, com base em princípios da Teoria da Subjetividade. 


\section{2-TERAPIA OCUPACIONAL}

\subsection{Características históricas e fundamentos}

Diversos fatores históricos construíram a profissão de terapeuta ocupacional ao longo do tempo. O surgimento desse campo profissional se entrelaça com o caminho do desenvolvimento da utilização das atividades como forma terapêutica. Assim sendo, é mster a retomada histórica sobre as diferentes finalidades com as quais elas foram sendo utilizadas. Os modos com que foram sendo aplicadas refletiram em bases e modelos teóricos da profissão, que influenciaram as diversas práticas adotadas pelos profissionais em diferentes épocas e com repercussões nas práticas atuais.

Na perspectiva da antiguidade, encontra-se a influência de gregos e romanos em relação ao modo como eles utilizavam a atividade, porém não se pode afirmar com segurança sobre essa origem. "Acreditava-se que os trabalhos, exercícios, artes e artesanatos poderiam 'curar' aqueles que estivessem 'possuídos pelo demônio', e a todos os doentes eram oferecidos ocupações, com o propósito de manter o ambiente tranquilo e favorecer o contato com os 'deuses"' (DE CARLO e BARTALOTTI, 2001, p. 19).

Entretanto, segundo as autoras De Carlo e Bartalotti (2001), encontram-se origens mais concretas entre os séculos XVII e XVIII, quando foram adotadas práticas de isolamento e exclusão de pessoas marginalizadas socialmente, como prostitutas, idosos, pessoas com deficiência, loucos, entre outros. Esses indivíduos eram colocados em um mesmo espaço físico, com o objetivo de manter a ordem social. Destarte, baseado nessa concepção, surgiu uma das principais origens concretas da Terapia Ocupacional: o Tratamento Moral, como nova forma de tratamento do doente mental. Originário na França e proposto por Pinel, tinha como objetivo modificar e corrigir hábitos errados e, ao mesmo tempo, criar e manter hábitos saudáveis de vida, visando à normalização do comportamento desorganizado do doente. Para isso eram utilizadas atividades, inclusive laborativas, a fim de manter o indivíduo ocupado e assim tentar normalizar o comportamento.

Ao mesmo tempo, de acordo com as autoras, com o crescimento do cientificismo, tem-se o advento da Filosofia Positivista e, com isso, passou-se a priorizar aspectos mais organicistas no tratamento da doença mental. Têm-se a valorização de questões 
individuais, como o próprio cérebro e suas implicações orgânicas, em detrimento de questões mais ambientais, como as propostas pelo Tratamento Moral. Porém, segundo Kielhofner e Burke (apud De Carlo e Bartolotti, 2001), no século XX, houve a retomada do Tratamento Moral juntamente com a nova "Teoria da Psicobiologia" de Adolf Meyer"1, baseada na relação entre padrões de hábitos e doença mental. Dessa forma, o indivíduo passou a ser visto como um ser complexo, sendo necessário adotar mecanismos que organizassem o seu comportamento e estilo de vida.

Aliado a essas questões, outro fator que influenciou o surgimento da profissão foi o cenário internacional pós I Guerra Mundial. Esse contexto levou à necessidade de (re)adaptar pessoas para que fossem produtivas socialmente, passando-se a valorizar o tratamento pela ocupação, tanto em relação ao incapacitado físico, como mental. Para isso, realizava-se um treinamento de hábitos, ou seja, um treino das atividades habituais que os indivíduos efetuavam no seu dia a dia, a fim de restabelecer a execução delas. Os maiores reflexos dessa concepção ocorreram primeiramente nos Estados Unidos, sendo criada a primeira escola profissional de Terapia Ocupacional em 1917, enquanto em outros países como na Inglaterra, a profissão foi estabelecida no período da II Guerra Mundial (DE CARLO, BARTOLOTTI, p. 27).

No século XX, a utilização terapêutica da ocupação passou a ser mais reconhecida. Com isso, na segunda década do referido século, surgiu a profissão de Terapeuta Ocupacional, como uma especialidade médica, sendo os primeiros cursos e programas teóricos oferecidos por médicos, com auxílio de enfermeiras e assistentes sociais (DE CARLO, BARTOLOTTI, p. 27). Essa época articula-se com o primeiro princípio dos fundamentos teóricos da Terapia ocupacional: a busca pelo significado da ocupação humana. Para Kielhofner ${ }^{1}$ (1982, apud Francisco, 2001), esse fundamento justifica-se por fatores como: reconhecimento do ser humano com uma natureza ocupacional; a interferência da doença no rompimento da ocupação; e a utilização da ocupação como organizador do comportamento. Segundo o documento "Estrutura da Prática da Terapia

\footnotetext{
${ }^{1}$ Psiquiatra suíço de origem norte-americana que desenvolveu o conceito de "higiene mental", como uma capacidade de manter a saúde mental. Uma de suas principais obras foi "Psicobiologia"(1957).
} 
Ocupacional: Domínio e Processo" da Associação Americana de Terapia Ocupacional (AOTA):

\begin{abstract}
"A profissão de terapia ocupacional utiliza o termo ocupação para captar a dimensão e o significado da -atividade do cotidiano. A terapia ocupacional é fundamentada na compreensão de que o envolvimento em ocupações estrutura a vida cotidiana e contribui para a saúde e para o bem-estar" (p. 61).
\end{abstract}

Para Francisco (2001), durante a década de 1940-50 nos Estados Unidos, ocorreu um crescimento do conhecimento científico na área da saúde, influenciada por um movimento denominado Reducionismo. Houve modificações no modelo médico, o que exigiu também no campo da Terapia Ocupacional ações mais definidas, baseadas em procedimentos e técnicas bem delimitadas e justificadas cientificamente. Dessa forma, aconteceram alterações no uso terapêutico da atividade, a fim de alcançar maior status científico, pois essa forma de tratamento era vista como não científica. Essa questão se intensificou mais, de acordo com De Carlo e Bartolotti (2001), nas décadas 1940-60, pois a Terapia Ocupacional sofreu fortes influências do Movimento Internacional de Reabilitação, surgido da grande necessidade de tratamento da população de atendimento nas disfunções físicas, em consequência da II Guerra Mundial.

Nesse sentido, ocorreram mudanças nas estratégias de tratamento adotadas na Terapia Ocupacional, o que pode ter representado um retrocesso visto a redução da atuação profissional, que se limitou aos aspectos físicos e observáveis da atividade, conforme critica a autora Francisco (2001, p. 31), “o modelo do homem, se adaptando ao meio social, possuidor de uma natureza ocupacional em sua essência, foi substituído por um modelo mecânico e progressivo linear”.

Surge, pois, o segundo embasamento teórico da profissão, a atividade vinculada a exercícios. O uso da atividade reduziu-se a exercícios biomecânicos de treino e adaptação, com objetivo de resgate funcional, vinculadas a questões anatômicas e patológicas. Para a autora, nesse período, apareceram procedimentos tradicionais na prática da Terapia Ocupacional, como a análise e adaptação da atividade, com o intuito de que o uso da atividade adquirisse um caráter mais científico. A ênfase dada a esses procedimentos muitas vezes levaram os profissionais a ignorarem outras questões relacionadas ao 
processo terapêutico, como as questões contextuais e relacionais que envolvem as ocupações, assim como quem as realiza.

A análise da atividade permite compreendê-la minuciosamente em suas propriedades específicas, ou seja, os componentes físicos e mentais necessários para realizá-la. Com isso, o terapeuta identifica quais exercícios são mais adequados para treinar os componentes específicos para sua realização, sendo que eles devem ser repetidos determinadas vezes para alcance dos objetivos, com influência de roteiros específicos. Então, novamente, Francisco (2001) critica o foco na análise da atividade e a desvalorização de aspectos mais amplos que a engloba, apontando que "ao realizar-se uma análise a atividade passa, então a ser uma série de ações deixando de lado o todo, a atividade em si” (p. 33). A partir dessa colocação e com base na abordagem teórica que se visa trazer para este trabalho, fica evidente a desconsideração da pessoa enquanto sujeito de sua ação no processo terapêutico e a importância de se refletir sobre mudanças em determinadas abordagens terapêuticas.

Outro procedimento, segundo a autora, é a adaptação das atividades ao tratamento e, para isso, tornam-se necessários alguns critérios, tais como: que a atividade favoreça mais movimentos do que posicionamento; que ela possa ser graduada e seja capaz de favorecer um número considerável de repetições do movimento; e que ela possa ser divida em fases ou etapas.

Por fim, outra ação adotada, devido a sua utilização científica, é a seleção e graduação da atividade. Ao trabalhar nessa perspectiva, os terapeutas consideram que o objetivo da seleção e graduação da atividade é a possibilidade de restaurar as ações que foram perdidas ou dificultadas (FRANCISCO, 2001). A atividade, ao ser graduada, significa que pode ser modificada em relação ao tempo, frequência de realização, em relação a movimentos e instruções das mais simples às mais elaboradas, a fim de que os objetivos propostos sejam alcançados.

Portanto, para a autora, pressupõe-se que, nessa perspectiva teórica, sejam utilizadas atividades estruturadas, a fim de facilitar a análise, graduação e adaptação delas. Elas podem ser divididas em etapas para se chegar a um todo, por exemplo, fazer um bolo, pois essa atividade se estrutura em fases e sequências, que podem ser analisadas e graduadas para se chegar ao objetivo final. No entanto, algumas atividades que não se 
enquadram corretamente nessa estrutura, como as plásticas (pintura, desenhos, esculturas etc) ou de lazer (passeios, brincadeiras etc), não são privilegiadas nesse modelo.

Esse contexto configura-se importante para compreender a história da Terapia Ocupacional no Brasil, pois foi justamente na época do uso da atividade de forma estruturada, limitada a exercícios mecânicos, que emergiram as primeiras instituições e os cursos inaugurais de formação no país. Os primeiros espaços institucionais foram criados na segunda metade do século XIX, nos estados do Rio de Janeiro, São Paulo e Minas Gerais, atendendo pessoas com incapacidades físicas, sensoriais (deficiência visual e auditiva) e doentes mentais (DE CARLO, BARTOLOTTI, 2001).

Segundo De Carlo e Bartolotti (2001), a vinda da Família Real portuguesa foi um marco histórico da utilização das ocupações como forma de tratamento no Brasil, promovendo a reestruturação no tratamento psiquiátrico. Seu início se deu com a criação do Hospício D. Pedro II em 1852, no Rio de Janeiro.

Na primeira metade do século XX, apareceram outros trabalhos baseados nas ocupações para pacientes internados, como atividades rurais, mecânicas, marcenaria, jardinagem, entre outras. Essas atividades se baseavam nos princípios do tratamento moral, ou seja, que a modificação do ambiente e a utilização de ocupações proporcionam a reorganização do comportamento.

Em relação à área de reabilitação física, em decorrência do Movimento Internacional de Reabilitação, surgem no Brasil, em 1940, os primeiros programas nessa área. Contudo, enquanto esse movimento tinha mais impacto nos países que participaram das duas grandes guerras, "no Brasil havia uma maior preocupação com pacientes crônicos (como os portadores de tuberculose), deficiências congênitas, acidentados no trabalho, de trânsito, domésticos ou por doenças ocupacionais" (DE CARLO, BARTOLOTTI, 2001, p. 31).

Com influência da ONU (Organização das Nações Unidas) e dos Estados Unidos, intensificaram-se no Brasil cursos de formação e a criação de centros de reabilitação na área física. Dessa forma, economicamente, para o Estado seria melhor reabilitar os incapacitados físicos, do que ter a redução do número de pessoas ativas no mercado de trabalho. 
Em 1969, as profissões de Terapia Ocupacional, juntamente com a Fisioterapia, foram reconhecidas como de nível superior (DE CARLO, BARTOLOTTI, 2001). Primeiramente o curso de Terapia Ocupacional originou-se na USP (Universidade de São Paulo), passando a fazer parte da Faculdade de Medicina da Universidade de São Paulo. E em 1999, passou a ter um departamento próprio, o Departamento de Fisioterapia, Fonoaudiologia e Terapia Ocupacional, da Faculdade de Medicina da USP. A organização curricular atual do curso, de acordo com algumas Universidades do país, como USP- SP, UFRJ (Universidade Federal do Rio de Janeiro), UFMG (Universidade Federal de Minas Gerais) e UNB (Universidade de Brasília) apresenta eixos norteadores. As disciplinas se estruturam em blocos inicialmente mais gerais, que contém disciplinas como Biologia, Anatomia, Fisiologia, Cinesiologia, Políticas Públicas, Saúde e Sociedade, Sociologia, Antropologia, Cultura, Psicologia do Desenvolvimento, Desenvolvimento Infantil, Metodologia e Fundamentos da profissão de Terapia Ocupacional. E disciplinas mais específicas à prática da TO, tais como: Atividades e Recursos Terapêuticos e atuação em contextos específicos (infância, gerontologia, hospitalar, mental, social, entre outros), e estágio ao final do curso. Na UNB, porém, esses conteúdos aparecem de forma distinta das outras universidades, sendo as disciplinas específicas da profissão estruturadas de acordo com eixos de complexidade e etapas do processo terapêutico (Atenção Básica, Média e Alta Complexidade e Avaliação, Recurso e Intervenção).

$\mathrm{Na}$ década de 70 e 80 , “o terapeuta ocupacional passa a se questionar sobre as condições em que se encontram seus pacientes e o espaço de contradição que ele próprio ocupa, entre uma função terapêutica, de um lado, e uma função de controle social, de outro" (CASTRO, LIMA, BRUNELLO, 2001, p. 44). Esses profissionais passam, então, a se questionar sobre a sua prática condicionada, muitas vezes, a questões ideológicas das instituições. Têm-se a utilização das ocupações aliadas aos objetivos e interesses institucionais, como por exemplo: a realização de atividades de jardinagem, de culinária, limpeza, ou atividades recreativas para ocupar o tempo, distanciando-se da real necessidade dos pacientes.

Para as autoras, partindo desse contexto, dois movimentos no campo da saúde contribuíram para um redimensionamento das atividades e práticas na Terapia Ocupacional. O primeiro foi a organização de grupos em prol das pessoas com deficiência, que passaram a lutar por direitos iguais aos outros cidadãos; o segundo 
referiu-se a propostas de desinstitucionalização na área psiquiátrica, objetivando garantir, a essas pessoas, direitos relacionados ao exercício da cidadania.

Além disso, de acordo com De Carlo e Bartolotti (2001), outro contexto que permitiu um redimensionamento da prática da Terapia Ocupacional, com início nas décadas de 1960 e 70 na América do Norte, na década de 80 na Inglaterra e de forma mais recente no Brasil, foi a discussão sobre necessidades de serviços mais comunitários e preventivos. Dessa forma, buscou-se também a utilização de estratégias e procedimentos de prevenção e manutenção da saúde, e não somente ações curativas.

Ambos os movimentos, tanto na área física como mental, assim como o contexto dos serviços comunitários, propuseram um novo modelo de reabilitação, uma reabilitação psicossocial, visando inserir o sujeito em espaços sociais, que procurava desconstruir a lógica excludente e alienante vigente. Com isso, permitiu-se um novo olhar para as atividades:

“[...] que passam a ser vistas e valorizadas como elemento articulador entre o sujeito e sua comunidade, representando, assim, oportunidades de encontro e diálogo entre os diferentes indivíduos da sociedade e possibilitando a emergência de produções significativas e desalienadoras, que envolvem um sujeito inserido em determinado tempo e espaço". (CASTRO, LIMA, BRUNELLO, 2001, p. 45).

Nos anos 1990, segundo as autoras, Castro, Lima e Brunello (2001), houve uma maior preocupação em reabilitar questões além dos aspectos individuais, mas também os espaços e relações em que o indivíduo se insere. Observa-se, assim, um distanciamento da profissão em relação ao modelo biomédico focado na reabilitação da patologia e utilização de atividades específicas, passando o paciente a ser visto de forma mais ampla. E assim:

"A nova direção da prática da Terapia Ocupacional propõe uma atuação no campo das possibilidades e recursos, de entrada no circuito de trocas sociais: o lúdico, o corpo, a arte, a criação de objetos, os estudos e o conhecimento, a organização dos espaços e o cuidado com o cotidiano, os cuidados pessoais, os passeios, as viagens, as festas, as diversas formas produtivas, a vida cultural, são alguns exemplos de temas que referendam, conectam e agenciam experiências, potencializam a vida, promovem 
transformações, produzem valor" (CASTRO, LIMA, BRUNELLO, p. 46/47).

O campo atual de intervenção da profissão estruturou-se a partir de fatores históricos e contextuais, atuando com diversos sujeitos e grupos, em diferentes faixas etárias e contextos, tanto na área da saúde, como educação e contextos sociais. Devido a isso, os locais de atuação são amplos, tais como: hospitais, ambulatórios, clínicas, centros de reabilitação, Centros de Atenção Psicossocial (CAPS I, II e III, CAPSi, CAPSad), centros de saúde, sistemas prisionais, asilos, abrigos, creches e escolas, entre outros.

Porém, para De Carlo e Bartalotti (2001), essas ações delinearam no campo da Terapia Ocupacional a coexistência de atuações aparentemente contraditórias entre si. Por um lado, têm-se serviços altamente especializados no uso de técnicas e tecnologias com grande avanço científico; por outro, aparecem trabalhos direcionados às comunidades mais carentes, utilizando estratégias para a melhoria da qualidade de vida dessa população, levando a profissão a ter como público alvo tanto aqueles considerados "diferentes" (pessoas com deficiência física, mental, sensorial etc), como aqueles com quadros clínicos e agudos de rápida recuperação, e sujeitos em condições de riscos sociais e/ou pessoais. No entanto, talvez o amplo campo de possibilidades de atuação do terapeuta ocupacional possa levar a um desconhecimento sobre suas ações práticas.

\subsection{Ações em Terapia Ocupacional}

Um dos principais objetivos da TO é resgatar a autonomia e a participação do usuário em contextos de desempenho, proporcionando a ele maior qualidade de vida, valorizando suas potencialidades e promovendo sua (re)inserção social. Logo, é função do terapeuta criar condições para que as pessoas realizem de forma mais autônoma possível suas ocupações diárias, que são atividades que "preenchem" o cotidiano e dão sentido à vida dos sujeitos. As atividades se constituem duplamente no processo terapêutico tanto como fim, ou seja, como objetivo que pretende ser alcançado, como o meio, posto que é utilizada como um recurso para se alcançar o objetivo almejado. 
A profissão, portanto, utiliza as atividades humanas como um dos recursos terapêuticos, com objetivo de desenvolver, prevenir e/ou restaurar habilidades e capacidades que foram afetadas em decorrências do aparecimento de danos físicos, motores, psíquicos e sociais, e que interferiam na autonomia do sujeito na realização de suas atividades cotidianas. Por outro lado, conforme destaca Trombly (2005), as atividades, ao serem consideradas como ocupações, podem representar também a finalidade da intervenção terapêutica.

As ocupações adquirem diversas definições, porém, de forma geral, são todas aquelas atividades que constituem o cotidiano de cada sujeito, estabelecendo relação mais ampla com a cultura e de forma mais específica com o significado singular para cada indivíduo. Destarte, a profissão foca suas intervenções nas ocupações humanas, considerando que elas requerem componentes de desempenho subjetivos (emoções) e físicos (observáveis e mensuráveis) para a sua realização. Elas são amplas e complexas, o que permite, segundo o documento oficial da Associação Americana de Terapia Ocupacional (AOTA), "Estrutura da Prática da Terapia Ocupacional: Domínio e Processo", serem classificadas nas seguintes áreas: atividades de vida diária (AVD’s), atividades instrumentais de vida diárias (AIVD`s), descanso e sono, educação, trabalho, brincar, lazer e participação social.

As AVD’s são aquelas atividades que correspondem ao cuidado do individuo com seu próprio corpo, como: higiene pessoal e autocuidado, mobilidade, alimentação, atividade sexual, uso do vaso sanitário, entre outras. As AIVD’s englobam as atividades relacionadas ao gerenciamento com a vida dentro de casa e em comunidade, são, por exemplo: preparar refeições e limpar a casa, gerenciamento financeiro e da própria saúde, cuidar de crianças e animais, mobilidade na comunidade, fazer compras, estudar, entre outras ocupações.

Porém, apesar de serem enquadradas nessas áreas, as ocupações possuem aspectos singulares e diversificados necessários para sua realização. Dessa forma, o documento aborda aspectos relacionados às ocupações, que devem ser considerados no processo terapêutico. São eles: as habilidades de desempenho, padrões de desempenho, contextos de desempenho e fatores da pessoa, que no documento é identificado como fatores do cliente. 
As habilidades de desempenho, de acordo com o documento, são "definidas como as habilidades que os clientes demonstram nas ações que desempenham" (p. 75). São inter-relacionadas entre si e classificadas como: habilidades práxica e motora, habilidades percepto-sensoriais, de regulação emocional, cognitivas, sociais e de comunicação. Essas habilidades não são sempre fixas, são dinâmicas, e podem ser influenciadas pelo contexto de desempenho, pelas características específicas inerentes a cada atividade, pelos padrões de desempenho, pelas funções e estruturas corporais, bem como por questões emocionais, ou seja, pelos fatores do cliente.

Os fatores do cliente são habilidades específicas, inerentes a cada pessoa, fundamentado em características físicas, mentais ou emocionais e crenças pessoais que podem afetar o desempenho nas atividades (AOTA, 2010). Portanto, o terapeuta deve considerar essa individualidade presente nas ocupações, que apesar de possuírem categorias universais, adquirem características únicas para cada indivíduo. Além disso, existem também as demandas específicas que cada atividade precisa, sendo necessária a análise e sistematização da sua realização dentro do processo terapêutico.

Os padrões de desempenho compreendem "hábitos, rotinas, papéis e rituais usados no processo de envolvimento em ocupações ou atividades" (AOTA, 2010, p. 78). Assim, os padrões relacionam-se com o modo com que cada indivíduo desempenha as atividades, o que se vincula diretamente com questões sociais. Os contextos e ambientes de desempenho englobam a diversidade de condições que se inter-relacionam ao redor do cliente e a influência dessas questões no desempenho ocupacional. Os contextos incluem o temporal, pessoal, cultural e virtual. O ambiente se refere ao espaço físico e social que cerca o sujeito durante suas ocupações.

As considerações e definições em relação ao processo terapêutico, apresentadas no documento da AOTA, são retratadas com o fito de nortear a prática em Terapia Ocupacional. Porém, na práxis, cada profissional é responsável por conduzir esse processo. Por exemplo, as atividades, quando utilizadas na Terapia Ocupacional como um recurso terapêutico, estão vinculadas à abordagem com que cada profissional as utiliza, podendo ser, por exemplo, a partir do modelo positivista, humanista e dialético.

Nascimento (1990) critica a existência de um mito pautado na atividade terapêutica na atuação da Terapia Ocupacional. Esse mito se baseia em considerar que 
qualquer atividade pode ser terapêutica, sendo somente necessário que o profissional a utilize com esse objetivo. Porém, muitas vezes as atividades são utilizadas de forma aleatória e banalizadas, ou seja, como exercícios, devido à superlotação de muitas instituições e à falta de um atendimento mais individualizado a cada paciente, ou como forma de ocupar o tempo. Ao longo da história, muitos terapeutas que trabalhavam em instituições de saúde mental utilizaram as atividades como um recurso para ocupar o tempo e para favorecer interesses institucionais próprios, por exemplo, atividades recreativas, de jardinagem, de limpeza, entre outras, sem finalidade terapêutica específica. Outra questão que intensificou a utilização indiscriminada da atividade foi quando o papel delas se reduziu a exercícios de treino e reabilitação de funções específicas. Esse contexto, conforme problematiza a autora, influenciou a forma com que muitos terapeutas ocupacionais passaram a lidar com a atividade.

"As atividades são vistas, geralmente entre os terapeutas ocupacionais, como contendo em si mesmas propriedades terapêuticas que cabe ao terapeuta descobrir, através da análise de atividades, e adequar ao quadro patológico" (Nascimento, 1990, p. 18).

Muitos terapeutas acabam focando sua atuação nas propriedades terapêuticas intrínsecas da atividade, utilizando-as de acordo com determinada patologia. Em contrapartida, desconsideram aspectos externos, como o contexto, inclusive, a pessoa que a realiza. É necessário refletir sobre os contextos e as práticas, a fim de repensar ações terapêuticas.

Para Nascimento (1990), apesar de já ter sido superado o mito da supervalorização das atividades em Terapia Ocupacional, observa-se um novo mito, que também pode levar a equívocos, como o de considerar as atividades como terapêuticas simplesmente quando se estabelece relação na tríade terapeuta-paciente-atividade. Enfatiza o papel da atividade novamente como um remédio vinculado unilateralmente a aspectos relacionais, ou seja, considera-se que ao estabelecer a boa relação na tríade, o processo terapêutico se torna positivo. No entanto, na visão da autora, é necessário desviar o olhar para a atividade e concentrar no sujeito, considerando que uma das principais intervenções consiste em torná-lo um ser possuidor de direitos políticos, exercendo seu papel como cidadão. Esse posicionamento da autora pode indicar uma possibilidade de articulação com o 
embasamento teórico deste trabalho, a partir de ações que valorizem a emergência do paciente como um sujeito de suas ações.

Para Castro, Lima e Brunello (2001), as atividades relacionam-se com as necessidades humanas, envolvendo uma realidade exterior e psíquica. A realidade exterior são questões básicas de existência (alimentação, moradia, educação, transporte, entre outras); e a realidade psíquica são questões subjetivas, ou seja, a forma como o sujeito percebe seu estado de bem-estar, sua satisfação, propósito de vida, relação com as pessoas, entre outros. Essa complexidade envolvida na atividade permite redimensionar a abrangência do conceito de qualidade de vida, que vai além do que aparentemente é observado. Conforme as autoras citadas, ao utilizar as atividades como recurso terapêutico é possível conhecer a história de vida dos sujeitos, pois elas favorecem um resgate de interesses, habilidades, potencialidades que delineiam caminhos possíveis de atuação.

"O que se estabelece no decorrer de atividades em Terapia Ocupacional é um campo de experimentação, no qual se instala um processo dinâmico, caracterizado como fio condutor de uma história peculiar, que se constrói na relação terapêutica, a cada momento ou situação, de modo sempre singular" (p.47).

Podemos perceber a complexidade com que as autoras retratam sobre as atividades no processo terapêutico, sendo possível abranger questões subjetivas que contribuem para a condução singular do terapeuta de acordo com as especificidades de cada pessoa. Sendo possível, para as autoras (p. 51), em qualquer atividade:

\footnotetext{
"tomar a técnica mais básica e simples, modificá-la e personalizá-la até transformá-la em algo que motive o fazer e crie possibilidades de percepção de como fazemos, engendrando curiosidade, interesses e prazer em resolver qualquer desafio com envolvimento, estabelecendo relacionamentos diretos, pessoais $\mathrm{e}$ interativos $[\ldots] "$.
}

Essa flexibilidade proposta para as atividades no processo terapêutico, que permite modificações e personalizações de acordo com cada ser humano, destaca o resgate da individualidade nesse processo. Portanto, enquanto recurso, as atividades podem representar um meio de se alcançar a pessoa, visto que elas permitem dentre outras 
coisas, conhecer sua história, assim como o que a motiva. Essa abordagem de utilização das atividades abre campos de possibilidades de reflexões sobre transformações nas práticas terapêuticas, buscando o resgate do sujeito nos processos em saúde em detrimento das técnicas padronizadas. Além disso, as autoras destacam sobre as atividades lúdicas, expressivas e artísticas que permitem diversificadas experiências para o sujeito, possibilitando transformações dos elementos da realidade em novas configurações, facilitadas pelo processo de imaginação favorecida por elas. Dessa forma, possibilitam reformular questões pessoais, como em relação à própria existência, sendo fundamental a comunicação e o diálogo nesse processo.

Ao analisar esse posicionamento das autoras em relação aos tipos de atividades (lúdicas, expressivas e artísticas), percebe-se uma contraposição com o modelo em que as atividades são utilizadas como exercício, retratada por Francisco (2001). Nesse modelo, é desconsiderado o uso das atividades por não serem passíveis de uma correta estruturação, ou seja, pela dificuldade de serem analisadas, divididas em etapas ou graduadas. Identifica-se que um mesmo recurso no processo terapêutico pode adquirir diferentes abordagens, de acordo com o posicionamento que o terapeuta adota em relação a elas.

Castro, Lima e Brunello (2001) destacam também que, ao se realizar as atividades, é possível criar novos sentidos e significados para experiências vividas, assim como compreender experiências que tenham ficado sem sentidos ou significados. Além disso, é importante que o produto final da atividade possua um sentido para o indivíduo ou para o grupo que a produziu, não sendo algo desconexo com o sujeito ou grupo. Ao relacionarem as atividades terapêuticas com questões de sentido e significado nas experiências, as autoras novamente destacam a valorização de questões subjetivas e do papel ativo do paciente nesse processo. Concluem, reposicionando o lugar da atividade na Terapia Ocupacional (p. 57):

"Assim, nessa perspectiva de atuação que compreende a conexão de espaços diferentes, sujeitos diferentes, projetos singulares e a aproximação de culturas diversas, é que se pode recolocar em questão as atividades em Terapia Ocupacional. Não se trata de construir modelos, receitas, bulas, indicações de atividades, mas de construir com cada paciente, junto com ele, uma trajetória singular, um projeto de vida, uma forma de sair das malhas aprisionantes de uma vida relegada a espaços muito restritos e estreitos." 
A partir dessas considerações, é valorizada a importância de se construir junto com ele, ou seja, permitindo ao "paciente" também ser ativo, sendo capaz de realizar escolhas e decisões em seu processo terapêutico. O novo olhar com que as autoras problematizam a atividade enquanto recurso dentro da TO articula-se com a importância de desconstruir métodos e técnicas padronizadas, baseadas em alguns modelos teóricos e abordagens que norteiam a prática de alguns terapeutas ocupacionais.

\subsection{Modelos teóricos práticos em Terapia Ocupacional}

As ações terapêuticas têm como base os princípios e fundamentos históricos, filosóficos e ideológicos que delinearam as práticas em Terapia Ocupacional ao longo de sua história. Estes foram se modificando e inovando, dando origem a modelos teóricopráticos que orientam muitas práticas atuais. Para Francisco (2001), ao se questionar como ocorre o processo terapêutico ocupacional, três linhas gerais são identificadas: modelo positivista, modelo humanista e modelo dialético, que interferem na forma como se constrói a prática terapêutica.

No modelo positivista, o centro do processo é a correção da patologia, com base na compreensão da saúde como ausência de doença, vinculada a aspectos biológicos. São priorizadas estruturas mais rígidas de procedimentos, ordenadas em sequência lógica, que possibilitam conhecer de forma ampla sobre a patologia apresentada pelo sujeito, a fim de se alcançar de forma mais adequada o objetivo final. As etapas dos procedimentos consistem em ações rígidas e bem delineadas, não permitindo muita flexibilidade. Segundo a autora, são elas: encaminhamento, entrevista inicial, avaliação (inicial e/ou completa), planejamento de programa de tratamento, tratamento propriamente dito, reavaliações e alta. As atividades terapêuticas estão vinculadas principalmente a exercícios e à produção, e em alguns casos, principalmente na área de saúde mental, as atividades aparecem como forma de expressão. Os atendimentos, preferencialmente, devem ser individuais, pois se compreende que a relação terapeuta-paciente efetiva-se unicamente por meio das atividades, portanto essa relação torna-se mais estruturada e com delimitações de papéis bem definidos. 
Por outro lado, no modelo humanista inexiste padrões e procedimentos a serem seguidos em sequência lógica, como entrevista, avaliação etc. A relação terapêutica ganha ênfase nessa concepção, sendo o principal instrumento de trabalho. O terapeuta proporciona um ambiente acolhedor de escuta a fim de favorecer o contato com o cliente, de modo que estimule o aparecimento de questões singulares trazidas por ele. Dessa forma, o centro do processo é o cliente, compreendendo que ele direciona os caminhos a serem seguidos, pois cada ser humano é único. Portanto, o objetivo é conhecer quem é o sujeito, os seus desejos e vontades, inclusive por meio de atividades, e, partindo disso, o terapeuta elabora o percurso terapêutico de acordo com essas características.

$\mathrm{Na}$ concepção dialética, a autora inicia sua definição a partir da reflexão crítica sobre o processo em TO. Muitos profissionais afirmam que priorizam o desenvolvimento do ser humano, a partir da consideração de suas características e personalidades singulares, com objetivo de promover a autonomia dos sujeitos, porém desconsideram o homem como um ser histórico e contextualizado socialmente. No modelo dialético, com base na concepção materialista da história, posiciona-se a saúde dentro de um contexto histórico e social, na busca da prática terapêutica que interfira positivamente na qualidade de vida, partindo do pressuposto que "a história da doença no indivíduo é sempre inseparável da sua história de vida, porque esta é em si mesma problematizadora" (FRANCISCO, 2001, p.65). O centro do processo terapêutico é o homem inserido dentro de um contexto, e não mais a doença ou somente o homem isoladamente. Com base nesse modelo, têm-se uma nova visão da saúde dentro do processo em TO, na qual não existem momentos nem fases distintas e específicas para realizar as avaliações e tratamentos, elas ocorrem de forma dinâmica. $\mathrm{O}$ foco terapêutico não se concentra sobre a doença, mas sobre a pessoa, que está permeada de relações e contextos sociais. A atividade, instrumento de intervenção do terapeuta, nessa perspectiva, relaciona-se com o trabalho, sendo ela um espaço capaz de promover a transformação tanto individual como social. Portanto, o processo terapêutico torna-se um espaço para refletir sobre o "fazer", que incluí atos, ações e atividades, possibilitando que "o paciente possa reconhecer-se com sujeito que cria, atua, reconhece, organiza e gerencia o seu cotidiano concreto" (FRANCISCO, 2001, p.66). Além disso, é possível também que ele se perceba como um ser social, envolvido em um sistema de relações.

Para a autora, entretanto, essas modificações ocorrem a partir do momento em que ele se apropria dos meios e objetivos do tratamento, reconhecendo-se em um papel ativo 
em sua história e na história do mundo. A partir da relação entre o individual e social, os atendimentos grupais ganham um destaque maior no processo, o ato terapêutico estruturase a partir das tensões dialéticas, baseadas em um caráter contraditório e não mais individual, conforme observado em dicotomias entre: saúde-doença; possibilidade/impossibilidade e autonomia/dependência. As ações terapêuticas ocorrem a partir de intervenções que facilitem a identificação de barreiras implicadas no fazer, que remetem a questões relativas ao modo de se relacionar e agir no cotidiano. Assim, a autora conclui que as ações da TO, dentro da visão materialista histórica, consistem em uma terapia que busca a conscientização contra a opressão, baseada na construção do fazer inserido nas práticas, relações e experiências do cotidiano.

De forma mais específica no contexto escolar, para Trevisian e Della Barba (2012), as ações da Terapia Ocupacional na educação inclusiva devem se apoiar no modelo interacionista. Esse modelo foca não somente na pessoa, mas também no contexto ambiental, físico e social em que ela se insere, e em tudo aquilo que dificulta a sua participação em seus contextos e atividades.

Esses modelos teóricos delineiam muitas práticas em TO, inclusive as ações em relação às ocupações que estão inseridas no cotidiano e o principal recurso utilizado no processo terapêutico: as atividades. Com base na proposição de um novo olhar para as práticas em Terapia Ocupacional, que possibilite ampliar a visão desses modelos, buscase a articulação da TO com um modelo que possibilite conhecer a complexidade do sujeito que realiza essas ocupações e atividades no processo terapêutico, compreendendo a influência do social em sua constituição. A Teoria da Subjetividade de González Rey, de base histórico-cultural, permite ampliar as concepções dos três modelos, pois favorece a visão que não foca somente na patologia, mas em compreender a complexidade desse fenômeno e sua articulação com a história do sujeito. Além disso, tem como foco o homem, não analisado individualmente, mas inserido em um contexto histórico e social, a partir da complexa articulação entre o social e o individual. Esse olhar nos parece possibilitar novas articulações com a prática em Terapia Ocupacional, e de forma mais específica, a partir de suas contribuições para o contexto educacional. 


\subsection{Terapia ocupacional e o contexto escolar}

Ao se analisar sobre a infância/adolescência, um dos principais ambientes de participação dessa população é a escola, estando permeada de atividades que se constituem como algumas das principais ocupações nessa faixa etária. Assim, ao ocorrer interferências que impeçam ou dificultem a participação dos sujeitos dentro desse espaço, ele passa a ser um contexto de atuação da Terapia Ocupacional, adquirindo um maior destaque de atuação na área da educação inclusiva. O TO pode ser um profissional hábil para intervenções no âmbito escolar, de acordo com Trevisian, Della Barba (2012) e Munguba (2007), por contribuir com o estudo do desenvolvimento humano e do processo de aprendizagem e autonomia não somente no contexto escolar, mas também fora dele.

A proposta da educação inclusiva não é tão recente. Ela sofreu a influência de movimentos e contextos internacionais, passando por diversas modificações. Para Marcelino (2013), é interessante analisar as diferentes abordagens com que as pessoas com deficiência têm sido consideradas socialmente ao longo do tempo. Após a época em que a pessoa com deficiência foi isolada e excluída da sociedade, têm-se o assistencialismo em relação a esse grupo de pessoas. Essa prática, segundo a autora, não valoriza as potencialidades do sujeito, que ficam encobertas por ações de caridade e proteção, condicionadas a tratamentos em instituições e no espaço familiar. Após esse período, sem considerar que ele tenha desaparecido totalmente, surgem as ações de integração e direitos iguais, que é quando essa população passa a ter o direito de ser integrada na escola, visto que ficou excluída por tanto tempo.

De acordo com Rocha, Luiz e Zulian (2003), o conceito de integração, com forte repercussão na década de 50, sofreu grande influência dos serviços especializados de reabilitação, com base no modelo biomédico. Dessa forma, o foco estava sobre o indivíduo, ou seja, ele deveria se tornar o mais "normalizado" possível para ter condições de se adaptar ao espaço escolar, sendo dado a ele o rótulo de herói ou coitadinho de acordo com o seu desempenho (ROCHA, 2007). Com a contribuição dos serviços especializados, a finalidade das intervenções consistia em minimizar as limitações e incapacidades, para facilitar a inserção do indivíduo tanto na sociedade como na escola. Na visão de integração, ainda se nota um forte vínculo com questões institucionais, assim como a grande responsabilidade depositada sobre os serviços de reabilitação, que têm o objetivo de "preparar" esses indivíduos para viver em sociedade, incluindo o ambiente escolar. 
Nesse contexto, de acordo com Rocha (2007), surgiu a Terapia Ocupacional na área educacional, com foco de intervenção na "educação especial".

\begin{abstract}
"A base do trabalho de Terapia Ocupacional no campo da "Educação Especial" se constituiu como uma extensão da atividade clínica desenvolvida nos serviços de reabilitação, que busca a normatização do comportamento, do desempenho motor funcional e do desenvolvimento cognitivo" (p.123).
\end{abstract}

Por volta do final da década de 80 , devido à influência de um forte movimento internacional denominado de Inclusão Social, aconteceu um redimensionamento da proposta de integração para inclusão escolar. Essa visão propõe uma rede de suporte coletivo, pelo qual as crianças da educação especial seriam inseridas em classes e escolas regulares de ensino. Surgiram diversas ações e leis nacionais e internacionais com foco nessa necessidade. No Brasil, a educação especial passa a ter maior visibilidade a partir da Constituição de 1988, que assegura a educação como direito de todos.

Em 1994, a UNESCO (Organização das Nações Unidas para Educação, Ciência e Cultura) juntamente com o governo espanhol firmaram a Declaração de Salamanca, que propõe que as escolas acolham todas as crianças, independente de suas condições. Para reafirmar essa discussão no Brasil, em 1996, é criada a Lei 9.394, que estabelece as diretrizes e bases da Educação Nacional com a inserção da educação especial e inclusiva como um de seus pressupostos no contexto educacional. Partindo dessas proposições, a inclusão passa a se basear na rede de suportes, onde o foco é a ação coletiva, e não mais o individuo. Portanto, não é mais o aluno que deve se adaptar a escola, mas a escola e a sociedade que devem se adaptar para acolher esse sujeito dentro de seus espaços (ROCHA, LUIZ, ZULIAN, 2003; LOURENÇO, CID; MARCELINO, 2013; DE PAULA, BALEOTTI, 2011).

Ao propor a substituição dos paradigmas de integração para inclusão escolar, espera-se que o ambiente seja capaz de se modificar para incluir o aluno. Dessa forma, um dos principais contextos que sofrem interferência nessa nova ordem é a escola que, para garantir efetivamente a inclusão, precisa sofrer transformações em seus aspectos físicos, pessoais, pedagógicos e relacionais. A instituição escolar apresenta-se como um 
espaço social constituído de normas e regras padronizadas, por isso, apesar das exigências na lei, na prática, esse processo ainda é um grande desafio, principalmente para as escolas.

Ide, Yamamoto e Silva (2011) realizaram um estudo em uma escola do município da Baixada Santista, em relação aos principais aspectos da inclusão escolar, de acordo com a visão das orientadoras pedagógicas. Nesse estudo, conclui-se que as principais dificuldades relacionadas à inclusão não se encontravam no aluno ou na deficiência, mas em todo o contexto escolar. A principal barreira, na visão das orientadoras, tanto para as crianças como para os professores, foi o ambiente, que compreende o espaço físico e as relações sociais. Para Rocha, Luiz e Zulian (2003) as barreiras arquitetônicas não são determinantes, muito embora dificultem o acesso.

Compreendendo a interferência de fatores contextuais no processo de inclusão, de acordo com alguns estudos realizados na área, outra barreira aparece relacionada com a formação dos professores. Para Zulian (2002, apud Rocha, Luiz e Zulian, 2003), ocorre um déficit na formação dos profissionais que trabalham de forma especializada com crianças com deficiência. No âmbito da educação especial, os profissionais trabalham em áreas fragmentadas, como por exemplo, deficiência mental, visual, auditiva. Portanto, segundo a autora, o foco de atuação profissional centra na patologia, enquanto os profissionais deveriam ser preparados de forma mais ampla para lidarem com os diferentes alunos e suas diversificadas possibilidades de aprendizagem. Apesar disso, muitas vezes, aparece a necessidade dos professores em conhecer questões específicas sobre a patologia, a fim de elaborar estratégias pedagógicas de acordo com cada especificidade dos alunos.

Toyoda et al. (2007) realizaram uma pesquisa na qual constataram a necessidade que os professores sentem de um suporte técnico na atuação com as pessoas com necessidades educacionais especiais. Um estudo realizado por De Paula e Baleotti (2011) sobre a inclusão de um aluno com deficiência física no contexto escolar, apresentou as principais dificuldades apontadas pela professora nesse processo. Em relação a sua prática, ela cita sobre a dificuldade no desenvolvimento de atividades que atenda a todos os alunos em suas especificidades, de modo que não gere exclusão, o que também está vinculado à falta de materiais adaptados para lidar com esses alunos. Além disso, retrata sobre a necessidade de capacitação profissional que contemple aspectos relacionados à inclusão de forma mais ampla, sem necessariamente estar vinculada à realização de cursos 
específicos para lidar com cada particularidade. A partir dessas condições, a professora retrata a importância do apoio de profissionais especializados no processo de inclusão escolar.

Observa-se, então, que os professores sentem necessidade em caracterizar, nomear e conhecer as deficiências e/ou transtornos, até mesmo como forma de orientar as ações pedagógicas. Além disso, principalmente em relação às dificuldades de aprendizagem, às vezes, há a necessidade ainda maior em caracterizar a origem desses "problemas" que interferem no processo de aprender, buscando geralmente uma origem orgânica para justificar tais dificuldades. Dessa maneira, geralmente se recorre à área da saúde para buscar a constatação de um diagnóstico, para que, com base nele, possam ser utilizadas no contexto educacional estratégias pontuais e delineadas. Assim, as autoras De Paula e Baleotti (2011) destacam:

\footnotetext{
"é preciso ter cautela para não atribuir à deficiência da criança a causa do fracasso escolar, medicalizando os problemas que são de ordem pedagógica e que se manifestam no cotidiano escolar (p. 61)".
}

Partindo dessa necessidade dos professores, observada na maioria dos estudos, nota-se a importância do suporte que os serviços de saúde podem oferecer para a inclusão escolar. Porém, é importante destacar que os serviços devem se articular com o contexto escolar como forma de apoio e suporte, compreendendo o limite de atuação de ambas as áreas, a partir das especificidades pedagógicas e terapêuticas inerentes a cada campo profissional. Os estudos de Rocha, Luiz e Zulian (2003) apontam para a escassez de atendimento por parte dos serviços de saúde e reabilitação a todas as crianças com deficiência, muitas vezes por falta de parcerias. E algumas vezes, quando têm, esses serviços agem de forma clínica e organicista,

“[...] voltada a aspectos exclusivamente individuais e referentes à patologia. Essa modalidade de participação também contribui para a construção do imaginário de que as questões da deficiência são do campo das especialidades, mesmo na educação. É como se o aluno, o professor e a escola, como um todo, necessitassem de "tratamento" para "aceitar" a criança com deficiência." (p.75). 
Toyoda et al (2007) apontam que, apesar da proposta de inclusão, o modelo de integração, que consiste em reabilitar e capacitar o indivíduo, ainda permanece na concepção de alguns profissionais da saúde e educação. Essa visão perdurou por muito tempo na prática de TO, e ainda pode ser encontrada atualmente. Esse modelo de reabilitação tem como foco a promoção do desenvolvimento funcional e minimização da patologia. Autores apontam para a necessidade dos terapeutas ocupacionais superarem práticas baseadas em paradigmas ultrapassados, com foco na reabilitação do indivíduo, a fim de considerar as diferenças contextuais que envolvem a deficiência. É necessário redirecionar o conceito de integração para inclusão para se repensar as ações em TO (DE PAULA, BALEOTTI 2011; ROCHA, 2007; TREVISIAN, DELLA BARBA, 2012). E assim:

"Ao abandonarmos o conceito de integração social, estamos abdicando do conceito de que a pessoa com deficiência "deve ser", prioritariamente, preparada para a sua inserção social e de que o papel do terapeuta ocupacional está voltado para a introdução de estratégias que minimizem as suas incapacidades. Negamos a proposição de normalização do comportamento e do corpo do indivíduo, bem como a sua culpabilização pela situação de marginalização e segregação social." (ROCHA, LUIZ, ZULIAN, 2003, p.73).

Para Rocha, Luiz e Zulian (2003), as ações da TO nesse contexto baseiam-se principalmente na construção de um novo sentido para as deficiências, com todos os envolvidos no processo de inclusão educacional. Sendo assim, as estratégias terapêuticas estabelecidas podem ser várias, envolvendo tanto recursos físicos como relacionais, dentre eles:

\footnotetext{
"o uso de tecnologia assistiva, as possibilidades de ações na dinâmica de grupos, assim como a análise de atividades, a facilitação das atividades da vida diária e da vida prática, a introdução da comunicação alternativa, entre outras" (p.75).
}

Essa diversidade de recursos que podem ser utilizados tem o intuito de possibilitar às pessoas com necessidades educacionais especiais terem maior autonomia e participação dentro de seus contextos de vida, facilitando questões de acessibilidade tanto física, como relacional. De acordo com as autoras, são adotadas intervenções mais gerais, como adequações ambientais, dos equipamentos e mobiliários, proporcionando um 
ambiente acolhedor e participativo para os sujeitos. Com objetivo de facilitar a comunicação e o acesso a recursos pedagógicos são utilizados recursos de comunicação alternativa e tecnologias assistivas e, ainda nessa direção, ocorre a articulação com recursos de informática. As Tecnologias Assistivas (TA) envolvem as comunicações alternativas e ampliadas, recursos para acesso ao computador, próteses, mobilidade alternativa, adaptações de postura, entre outros, sendo usados em diferentes contextos como na escola, em casa, no lazer ou no trabalho.

A utilização desses recursos na TO requer a análise das necessidades dos usuários e suas habilidades necessárias para esse uso. Além disso, o terapeuta precisa avaliar a receptividade do sujeito em relação a essa adaptação e modificação, assim como a relação com a condição sociocultural e as características físicas do ambiente (PELOSI, 2005). Essas tecnologias são, pois, todos os recursos que contribuem para ampliar as habilidades funcionais do indivíduo, aumentando sua autonomia e independência em seus diferentes contextos e atividades.

No campo das Tecnologias Assistivas, uma área bastante explorada no contexto educacional é a área da comunicação, com destaque para a comunicação alternativa e ampliada. Segundo Pelosi (2005), a comunicação alternativa engloba recursos que possibilitam aos sujeitos com dificuldades de comunicação estabelecer um contato com os que estão a sua volta, a fim de facilitar as relações entre eles. Essas comunicações podem ser estabelecidas de diversas formas, como por exemplo: expressões faciais, gestos, pranchas com símbolos, até mecanismos mais sofisticados como comunicadores de voz gravada, ou recursos de voz no computador.

Outro aspecto que merece destaque como uma das intervenções da TO nesse campo é a aquisição da escrita. $\mathrm{O}$ ato de escrever está entre as principais atividades do contexto escolar, visto que "na escola a impossibilidade de escrever causa muitos transtornos" (PELOSI, 2005, p. 42). Sendo assim, a valorização da escrita é um aspecto bastante significativo para os professores, assim como também para a família. Compreende-se que quando existem limitações para a realização dessa atividade, devido a questões físicas, motoras, cognitivas ou sensoriais, pode ocorrer a intervenção da TO a fim de promover a autonomia para sua realização. Em relação ao ambiente e a atividade de escrever podem ser utilizados recursos, como o uso de tecnologias assistivas e adaptações no modo de realizá-la. No âmbito individual, podem ser utilizados diversos 
exercícios terapêuticos com objetivo de reestabelecer componentes funcionais, motores, cognitivos ou sensoriais necessários para realizar a ação de escrever. Assim, podem ser utilizados recursos e ações alternativas para desempenhar tal tarefa.

Em termos relacionais, o terapeuta ocupacional contribui para favorecer a autonomia do professor, a partir de um suporte oferecido a esses profissionais, por meio do esclarecimento de aspectos específicos da deficiência. Porém, as ações inclusivas devem envolver todos os sujeitos em questão, ou seja, o aluno, a família, os professores e equipe pedagógica, os demais alunos e a comunidade escolar. Dessa maneira, podemos ter um maior destaque para as atividades grupais, que podem ser realizadas com todos os envolvidos, a fim de refletir e debater assuntos sobre a inclusão dentro da comunidade escolar.

Consoante Rocha, Luiz e Zulian (2003), as ações podem parecer objetivas e pontuais, mas indicam meios com o intuito de facilitar um diálogo, identificar o sentido que a deficiência adquire para todos os sujeitos relacionados no processo de inclusão escolar (professores, equipe pedagógica, familiares, demais alunos, comunidade, entre outros) e propor reconfigurações sobre interpretações equivocadas ou excludentes. Dessa maneira, as ações são abrangentes, sendo propostas diferentes atividades de acordo com o contexto e com todos os envolvidos, o que facilita, por meio delas, a emergência de possíveis impasses e suas soluções. A partir da análise do cotidiano e do contexto, identificam-se dificuldades explícitas no ambiente, como as barreiras arquitetônicas, aspectos do mobiliário e instrumentos pedagógicos, além de dificuldades implícitas, que envolvem aspectos relacionais, sendo trabalhadas em atividades coletivas e individuais.

São notáveis as contribuições do terapeuta ocupacional na área da educação. Em relação ao processo de inclusão escolar, de acordo com a pesquisa realizada por De Paula e Baleotti (2011), a professora colaboradora da pesquisa reconhece a atuação do TO como significativa, principalmente em relação às orientações, devendo ser realizada desde o início do ano letivo. Além disso, destaca a importância da parceria desse profissional com os professores a partir de troca de informações e conhecimentos entre as áreas, e da adequação do mobiliário, dos materiais e de orientações para professores e comunidades, entre outras ações. Conforme apontam Rocha, Luiz e Zulian (2003), mesmo quando atuam dentro do espaço escolar, as ações do terapeuta ocupacional não são 
exclusivamente clínicas, nem voltadas para aspectos específicos dos alunos com deficiência e muito menos para questões pedagógicas.

Durante algum tempo, a prática da TO no campo escolar passou a ter como foco a reabilitação individual e ações baseadas na modificação de aspectos físicos e observáveis, como as adaptações ambientais e eliminação de barreiras arquitetônicas. Posteriormente, a atuação ampliou para análises das diferentes abordagens de ensino no processo de ensino-aprendizagem, com intuito de intervir e propor diferentes estratégias pedagógicas para favorecer o processo de aprender dos alunos com necessidades especiais. Desse modo, as ações começaram a se confundir com as ações dos educadores, e os TOs passaram a ser mais desvalorizados por não possuírem formação específica em conteúdos pedagógicos. Porém, a partir de alguns trabalhos mais recentes como o de Jurdi et al. (2004) e Costabile e Brunello (2005), são propostas algumas modificações nas intervenções da Terapia Ocupacional no contexto da educação inclusiva (ROCHA, 2007). Com isso:

\begin{abstract}
"a ação passa a incidir no contexto do cotidiano, dos significados atribuídos às atividades e da superação das dificuldades relacionais emergidas com a presença de estudantes com ou sem deficiência. $\mathrm{O}$ objeto no qual ocorrem às intervenções adquire conotação de um sujeito coletivo, ou seja, o espaço escolar e suas relações." (ROCHA, 2007, p.124).
\end{abstract}

Pautadas em solicitações de profissionais da educação sobre práticas que contemplem atividades do cotidiano e relações estabelecidas nesse contexto, Jurdi, Brunello e Honda (2004) propõem a realização de intervenções com foco sob um novo olhar para o cotidiano escolar, a partir das relações estabelecidas entre os sujeitos e os conceitos e valores que os constituem e se relacionam com a deficiência, sendo necessário esse conhecimento prévio para propor intervenções nesse contexto.

Pretende-se, pois, compreender os conflitos além das situações de ensinoaprendizagem, mas como sendo historicamente construídos, envolvendo situações amplas e complexas. As autoras abordam a Terapia Ocupacional e propostas mais ampliadas, redimensionando a prática para além das clínicas, com um foco também sobre o social. Jurdi e Amiralian (2006) destacam, em relação à prática da TO na inclusão escolar de alunos com deficiência mental, a necessidade de novas intervenções que possibilitem no cotidiano um novo olhar para o aluno com deficiência, de acordo com 
suas potencialidades e singularidades, ou seja, "a possibilidade de construção de um cotidiano que se estabeleça através dos significados e desejos" (p.192/193). Portanto, a contribuição do TO no contexto educacional está além das necessidades educacionais especiais, mas também se relaciona com a vida diária desse aluno fora da escola (IDE, YAMAMOTO, SILVA, 2011).

A partir das considerações das autoras, percebe-se uma proposta de ampliação das ações em TO no espaço escolar, a partir de intervenções com foco em questões mais amplas, como o cotidiano e as relações sociais. Porém, apesar disso, conforme se observa nas pesquisas descritas nessa seção, em relação à atuação da Terapia Ocupacional no contexto educacional, percebe-se a ênfase em intervenções que têm como foco as deficiências e a promoção da inclusão escolar. Dessa maneira, a maioria das ações ainda acaba sendo pontuais, estando diretamente ou indiretamente interligadas com procedimentos e métodos padrões, que visam à reabilitação do individuo e modificações físicas e relacionais no espaço social que ele ocupa. Além disso, percebe-se que algumas vezes as intervenções indicavam ações isoladas, focadas em aspectos específicos, sem possuírem articulações significativas, sejam elas com o sujeito com deficiência, com o espaço físico, com os professores e/ou com a família.

O desenvolvimento do conceito de integração e inclusão no campo educacional também pode ter contribuído para delinear ações, nas quais podemos observar algumas dicotomias entre aspectos internos e externos. No modelo de integração, as ações têm como foco o individual, ou seja, reabilitar as aptidões físicas, mentais e sociais necessárias para o aluno ser capaz de ter acesso à escola. Porém, na inclusão, valoriza-se a transformação do contexto, incluindo aspectos relacionais e físicos, para que o ambiente esteja adequado para receber o aluno com necessidades educacionais especiais. Dessa maneira, ora a responsabilidade recai sobre o indivíduo, ora pra questões externas a ele. No entanto, as intervenções geralmente não consideram a complexidade do processo de aprendizagem, e a forma com que ele se organiza em uma dinâmica subjetiva singular, na qual as questões individuais e sociais estão inter-relacionadas, estando além de aspectos orgânicos, sejam eles relacionados à deficiência ou a transtornos.

No contexto de atuação da profissão, em relação aos aspectos educacionais, temse dado pouca atenção para intervenções cujo foco são as dificuldades de aprendizagem, que pressupõem a existência ou não de deficiência ou transtorno orgânico. No início desta 
seção, relatou-se sobre o terapeuta ocupacional ser um profissional hábil para contribuir com a área educacional, caso ocorram dificuldades de participação dos indivíduos nesse espaço. Nota-se que, durante muito tempo e ainda atualmente, as dificuldades de participação nesse espaço vinculam-se principalmente à questão da deficiência, o que permeia as principais intervenções nesse contexto, cujo eixo é a inclusão escolar. Porém, torna-se imprescindível captar a complexidade da dinâmica subjetiva dos sujeitos no processo de aprender, que geram implicações no contexto educacional, estando além da deficiência ou transtorno, indicando diversificadas possibilidades de ampliação da atuação da TO nesse âmbito.

À vista disso, torna-se relevante explorar o campo de atuação da Terapia Ocupacional no contexto das dificuldades de aprendizagem, como por exemplo, em relação aos alunos diagnosticados com TDAH (Transtorno do Déficit de Atenção e Hiperatividade). Segundo a Associação Brasileira do Déficit de Atenção (ABDA), o TDAH é um transtorno neurobiológico com origens genéticas, que surge na infância e geralmente acompanha o indivíduo por toda a sua vida. Os principais sintomas que o caracterizam são: desatenção, inquietude e impulsividade. De uma maneira geral, ao se referir sobre o transtorno, ganha destaque o tratamento medicamentoso, como por exemplo, o uso de Ritalina. A ênfase concedida à questão do medicamento muitas vezes obscurece outras diversificadas possibilidades de intervenção terapêutica e pedagógica com essa população. Moysés (2001) discute sobre a medicalização na educação, sendo um processo pelo qual os problemas que fazem parte do cotidiano dos indivíduos são deslocados para a área médica. Dessa maneira, surge a necessidade de enfatizar intervenções que tenham como foco investigar o contexto e cotidiano dos alunos com TDAH, compreendendo as implicações dessas questões no processo de aprendizagem.

As proposições das autoras (JURDI, BRUNELLO E HONDA, 2004; JURDI, AMARILIAN, 2006; IDE, YAMAMOTO, SILVA, 2011) a partir de intervenções além do espaço escolar, que tenham como foco as questão do cotidiano e as relações sociais, estimulam reflexões sobre diversificadas possibilidades de ações da TO, com base na compreensão da complexidade e singularidade inerentes ao processo de aprender. A vida cotidiana expressa-se de forma diversificada, conforme o contexto, e heterogênea em seu conteúdo e significado, tendo sentidos e modos de execução únicos para quem as realiza. Apesar de existirem inúmeras ocupações padronizadas que caracterizam o cotidiano da maioria dos sujeitos, inclusive daqueles que estão dentro de uma mesma cultura, o modo 
como cada sujeito se relaciona com elas é singular. "O cotidiano traz em si a marca da singularidade do sujeito, e toma forma a partir de suas necessidades, valores, crenças e afetos" (GALHEIGO, 2003, p. 106). Dessa forma, apesar de dois sujeitos estarem inseridos na mesma cultura, realizando a mesma ocupação, como por exemplo, estudar, o modo como cada um se relaciona e desenvolve a atividade é distinta, pois envolve questões subjetivas e singulares, que podem ser compreendidas dentro da história de cada indivíduo.

Para Galheigo (2003), a partir do momento em que se passa a considerar os conceitos de subjetividade, cultura, história e o poder social como elementos que influenciam na compreensão do cotidiano, ocorre um rompimento com a visão mais positivista e determinista. Os valores inerentes a cada pessoa relacionados à ética e à moral são considerados dinâmicos, mudando de acordo com a história e com as diversificadas culturas, podendo ser diferentes, apesar de estarem em um mesmo contexto e época. Dessa forma, o cotidiano não é composto por atividades padronizadas, realizadas de forma universal. Para Galheigo (2003), ao longo da profissão houve modificações em relação aos conceitos de treinamento das atividades de vida diária (AVD's) e atividades da vida prática (AVP’s), para ressignificação do cotidiano, ampliando a visão em relação à atuação terapêutica. Para a autora, ao analisar as origens dos conceitos de AVD's e AVP's na TO, encontra-se correspondência com o momento positivista da profissão, em que o foco no processo terapêutico eram unicamente as atividades, e os procedimentos e ações estavam vinculados a estratégias de mensuração e obtenção de dados. Portanto, na prática, os conceitos acabaram se tornando categorias universais, sendo utilizados nas avaliações de forma padronizada e mecanizada, desconsiderando fatores contextuais e singulares de cada sujeito no processo terapêutico.

Ao se priorizar como uma das ações da profissão a ressignificação do cotidiano, em detrimento aos treinos de AVD’s e AVP's, é possível resgatar o sujeito, assim como sua história e contexto, em contraposição à ideia de considerar o cotidiano como simples repetição mecânica de ações. A partir disso, a autora resgata o papel que a subjetividade e a autonomia adquirem na atuação terapêutica:

"Quando focamos na subjetividade, nos atentamos aos significados que as pessoas dão as suas experiências, isto é, à compreensão e interpretação que fazem de sua realidade social. Tal visão traz em si a ideia de que elas têm (ou buscam ter) autonomia de determinar o curso 
de suas vidas, exercendo livremente seus pensamentos e indo ao encontro de seus desejos e anseios" (GALHEIGO, 2003, p. 108).

A autora realiza um posicionamento interessante: ao se considerar a subjetividade no processo terapêutico, compreendem-se as características singulares de cada pessoa, juntamente com a capacidade inerente a cada ser humano de construir caminhos que lhes permitam serem sujeitos de suas ações. Dessa maneira, percebe-se a importância dos aspectos subjetivos e da valorização da autonomia de cada "paciente" como elementos inerentes ao processo terapêutico, o que o caracteriza como algo dinâmico e singular, não pode ser reduzido a práticas despersonalizadas e desconexas. A autora ainda complementa sobre a utilização de metodologias qualitativas a serem utilizadas no campo prático, que permitam compreender a pessoa, o cotidiano e a subjetividade do espaço social. Para ela, trabalhar com histórias e mapas ocupacionais, histórias de vida, narrativas e biografias permite ao sujeito recontar sua própria história, ressignificar seu cotidiano e se reconhecer como "fazedor de sua história e da história do mundo" (FRANCISCO, 2001, p. 67 apud GALHEIGO, 2003). Pode-se considerar que a autora reconhece a importância dos instrumentos terapêuticos como estímulos para processos de reflexão e mudança, sendo possível, a partir deles, ressignificar o cotidiano. Porém, enfatiza o papel ativo do paciente como capaz de construir a sua história e, ao mesmo tempo, a do espaço social em que ele se insere, articulando a dimensão individual e social como produção do sujeito.

Essas reflexões nos permitem articulações com a Teoria da Subjetividade de González Rey, a partir da consideração da emergência do sujeito no processo terapêutico, e dos conceitos de configuração subjetiva, subjetividade individual e social, que serão mais explorados na próxima sessão. A partir dessas reflexões e considerações sobre a atuação da TO no contexto educacional, verifica-se a importância da valorização das questões subjetivas, históricas e contextuais na prática terapêutica, de maneira mais específica, em relação à atuação nesse âmbito, tendo em vista a complexidade do processo de aprender. 


\section{3-TEORIA DA SUBJETIVIDADE E TERAPIA OCUPACIONAL}

De acordo com González Rey (2011), na instituição médica da saúde, assim como em praticamente todos os espaços institucionais, durante muito tempo, o tema da subjetividade manteve-se periférico. Para o autor, essa desconsideração dos aspectos subjetivos, culturais e sociais da saúde/doença sofreu grande influência do modelo biomédico, de base organicista. A crença nesse modelo levou a uma série de ações institucionalizadas que acabaram por fazer o ser humano se sentir indefeso, inseguro e sem capacidade de ação em relação a seu próprio adoecimento. O contexto baseado nas práticas médicas refletiu em outras profissões na área da saúde. Têm-se, por exemplo, na prática da Terapia Ocupacional, como anteriormente analisado, baseada no modelo positivista, o uso da atividade como um exercício, a fim de se recuperar funções e habilidades específicas, sem considerar aspectos subjetivos em sua prática, ou até mesmo, o próprio sujeito. Essa forma de atuação muitas vezes deposita grande valor aos exercícios em si mesmos, que devem ser repetidos, desvalorizando-se as capacidades intrínsecas do sujeito de se posicionar e gerar transformações pessoais, ou seja, de gerar caminhos alternativos em sua vida diante do adoecimento.

González Rey (2011b) propõe a introdução do conceito de subjetividade na clínica, a partir da Teoria da Subjetividade de base Histórico-Cultural proposta pelo próprio autor, que guarda relação com os trabalhos de Vygotsky. Na última fase de sua obra, Vygotsky introduziu a categoria de sentido na Perspectiva Histórico Cultural. Nessa etapa, o autor, em Pensamento e Palavra destaca a relação entre pensamento, palavra e linguagem, abordando uma visão mais ampla em relação à psique, como um sistema ativo e dinâmico e influenciado pelas emoções. O autor não traz, no entanto, uma definição clara sobre a categoria sentido, mas em sua obra ela vem definida como "a soma de todos os eventos psicológicos que a palavra desperta em nossa consciência, um todo complexo, fluido e dinâmico que tem várias zonas de estabilidade desigual” (VYGOTSKY, 1989, p. 181), integrando a unidade da cognição/afeto, e superando as dicotomias antes existentes. Segundo González Rey (2007), Vygotsky introduz a categoria sentido como uma nova unidade dentro da psique humana, enfatizando o caráter gerador dessa instância psicológica e a autonomia em relação às emoções, o que contribuiu para o desenvolvimento da Subjetividade dentro da Perspectiva Histórico-Cultural. 
A categoria de sentido impulsionou o desenvolvimento da Teoria da Subjetividade de González Rey sob a perspectiva Histórico Cultural. Mitjáns Martínez (2005) considera que, nesse campo teórico, a Subjetividade pode ser tanto uma Teoria como categoria. No que se refere ao status de Teoria, a subjetividade representa "um nível macroteórico para a construção do pensamento psicológico” (González Rey, 2012, p. 126). Segundo o autor, a Teoria apresenta-se como uma teoria básica e geral sobre a psique, permitindo a articulação entre os diferentes campos da psicologia aplicada, que muitas vezes representaram construções fragmentadas e parciais. Ela contrapõe as concepções racionalistas e mecânicas das instâncias psíquicas, que estão centradas na objetividade e na linearidade e que consideram fatores internos ou externos como determinantes do comportamento. A Teoria destaca o sistema complexo e singular que constitui cada ser humano em sua totalidade, a partir de suas experiências subjetivas singulares, que não são determinadas, a priori, por nenhum tipo de influência, sejam elas internas ou externas, mas representam uma produção dos sujeitos nos diferentes espaços e momentos que constituem a vida cotidiana. Dessa maneira, ela não se restringe unicamente às organizações intrapsíquicas individuais de forma objetiva e racional, como muito se abordava sobre a subjetividade, mas estabelece a relação entre o individual e social, a partir da produção diferenciada e simultânea de sentidos subjetivos que se relacionam nos dois níveis (González Rey, 2011b).

A Teoria discorre que, a partir da relação com as pessoas no contexto social, cada sujeito produz sentidos subjetivos singulares, reafirmando a complexidade presente nas experiências. As produções subjetivas ocorrem nos diferentes espaços sociais e se articulam constantemente com elementos subjetivos originários de diversos outros contextos e momentos de vivência das pessoas e podem ser constantemente construídas e reconstruídas através das ações dos sujeitos nos espaços sociais. Dessa forma, a Teoria da Subjetividade propõe romper com determinadas dicotomias, investigando fenômenos humanos que muitas vezes foram retratados de maneira isolada (por exemplo: a aprendizagem), a partir da unidade dinâmica indivíduo/social e da relação simbólico/emocional, com a interferência de fatores históricos e atuais, que permeiam o sujeito. Parte do pressuposto que toda produção humana é uma produção subjetiva (GONZÁLEZ, 2007a), enfatizando o caráter gerador da psique, ou seja, a existência da produção humana implicada nessa subjetividade, contrapondo a visão de internalização pura. 
Segundo o autor a Teoria não é determinista, sendo processual, dinâmica, sistêmica e pluri-determinada. A Subjetividade, enquanto teoria, abrange a complexa representação da psique humana, expressando-se por meio de um conjunto de categorias, tais como: sujeito, sentido subjetivo, configuração subjetiva, subjetividade individual, subjetividade social, que se articulam em torno da categoria mais ampla de subjetividade. Esta assume um papel central, influenciando no desenvolvimento de outras categorias do mesmo campo teórico.

A categoria subjetividade pode ser definida como um sistema de sentidos subjetivos que se organizam em múltiplas configurações singulares, que são expressas no momento da ação de cada sujeito, sendo diversificadas conforme os diferentes contextos e ações praticadas (González Rey, 2011b). Ela não se apresenta, portanto, como uma estrutura fixa, mas como um sistema dinâmico e processual de organização psíquica, que está em constante desenvolvimento e transformações, integrando aspectos internos e externos, históricos e atuais.

González Rey (2011b, p. 31) destaca que "nenhuma experiência vivida é portadora de uma significação psicológica pelo seu caráter objetivo". Desse modo, apesar de dois sujeitos vivenciarem uma mesma experiência, não é possível inferir que ambos terão a mesma significação psicológica em relação a ela. As experiências adquirem um caráter único e singular para cada sujeito que as vivencia, de acordo com os sentidos subjetivos produzidos a partir delas. No entanto, não se relacionam diretamente e somente com elas, uma vez que se articulam em configurações subjetivas específicas em cada sujeito. O autor (2002, 2007b) propõe a categoria sentido subjetivo, diferenciando-a da categoria de sentido de Vygotsky, por enfatizar a relação entre o simbólico-emocional e não somente entre o intelectual e afetivo. Ela passa a ser definida como:

\footnotetext{
“[...] a unidade inseparável do simbólico e do emocional, onde a emergência de um provoca a aparição do outro, sem ser a sua causa." (GONZÁLEZ REY, 2002, p.33).
}

Os sentidos subjetivos integram emocionalidades originárias de experiências diversas, que são organizadas na configuração da vida singular de cada sujeito. $\mathrm{O}$ autor aponta a complexidade com que esses sentidos subjetivos geram, rapidamente, cadeias simbólico-emocionais que se organizam em configurações subjetivas da experiência. 
González Rey (2011b) destaca, dessa forma, que apesar de estarem vinculados ao processo atual do qual emergiram, eles não podem ser compreendidos isoladamente. Por isso, o sentido subjetivo se caracteriza como uma produção histórica e atual, que sempre está articulada a quem o produz, ou seja, o sujeito, rompendo assim, com a dicotomia entre interno e externo e com os processos unicamente de internalização. O sentido subjetivo representa a categoria em constante processo de mudança, constituindo-se em produções singulares que não são definidas previamente, mas construídas ao longo da história de vida de cada sujeito. Dessa forma, os sentidos subjetivos emergem a todo instante, provocando mudanças na rede de configurações subjetivas dominantes na qual se constituíram.

As configurações subjetivas são as formas complexas de organização psicológica dos sentidos subjetivos, ou seja, é o modo como o sujeito organiza psicologicamente os eventos significativos em sua vida, a partir dos processos de produção de sentidos subjetivos. Nesse sentido, são as configurações do sistema da subjetividade, "as configurações subjetivas são as verdadeiras unidades da subjetividade humana, pois representam os momentos de convergência e mobilidade dos sentidos subjetivos que emergem na ação" (González Rey, 2011b, p. 34). As configurações, segundo o autor, formam um sistema aberto e dinâmico, ou seja, redes, onde os sentidos subjetivos encontram-se interligados, constituindo verdadeiras "redes simbólicas emocionais" (González Rey, 2011b, p. 34), que são incompreensíveis a partir da análise de expressões isoladas. A existência de complexas redes simbólicas emocionais rompe com a ideia de linearidade e objetividade, que muitas vezes é utilizada para explicar o comportamento humano, visto que, as expressões e comportamentos não devem ser analisados de forma isolada e pontual, mas compreendidos a partir da complexa configuração subjetiva singular que constitui cada sujeito. Para González Rey (2011b), as configurações subjetivas representam a unidade entre o histórico e o atual na organização da subjetividade, a partir da conservação dos sentidos subjetivos dominantes e a integração dos novos, estando esse processo constituído para além das intenções racionais e conscientes.

A relação existente entre as produções subjetivas de cada sujeito e o papel do social nessa produção demonstra a articulação que a Teoria permite realizar entre o individual e o social. Há uma relação complexa entre esses níveis, não sendo direta e 
pontual, no qual se considera o impacto do social nos processos psicológicos individuais. A relação entre ambas ocorre a partir da simultaneidade, rompendo com as dicotomias individual-social. Nessa perspectiva, a subjetividade individual e a subjetividade social se constituem mutuamente, sem uma determinação $a$ priori.

A subjetividade social pode ser definida como "[...] o complexo sistema da configuração subjetiva dos diferentes espaços da vida social que, em sua expressão, articulam-se estreitamente entre si, definindo complexas configurações subjetivas na organização social" (GONZÁLEZ REY, 2005a, p. 203). Ela se caracteriza como um sistema de organização subjetiva obtida a partir dos diferentes espaços sociais. Essa concepção permite superar a ideia de que a subjetividade se resume unicamente à pessoa, uma vez que está relacionada com a complexidade dos espaços sociais, sendo produzida em diferentes contextos como nas escolas, serviços de saúde, famílias, igrejas, grupo de amigos, entre outros. Diante disso, os processos sociais deixam de ser vistos como algo externo ao indivíduo e passam a ter relação com o processo de constituição da subjetividade individual, que também se manifesta na subjetividade social. Portanto, a constituição do social e do interno se articula constantemente e de maneira recíproca.

Por sua vez, a subjetividade individual "representa os processos e formas de organização subjetiva dos indivíduos concretos. Nela aparece constituída a história única de cada um dos indivíduos, que à luz de uma cultura se constitui em suas relações pessoais" (GONZÁLEZ REY, 2005a, p. 241). Nesse sentido, a partir das relações, do contexto social e da ação do sujeito, a subjetividade individual se constitui e se organiza dentro da história de vida singular de cada sujeito. Dessa maneira, têm-se o desenvolvimento de uma subjetividade individual constituída por elementos da subjetividade social, mas que adquire uma característica única de acordo com a singularidade de cada pessoa.

Nesse sentido, nota-se a participação dos espaços sociais na configuração da subjetividade individual, de acordo com os diferentes cenários nos quais o indivíduo está inserido. O ambiente terapêutico e escolar, assim como a família e outros contextos, estão permeados de representações sociais que caracterizam uma subjetividade social dentro desse espaço. Os espaços são constituídos por atores sociais que produzem sentidos subjetivos diversos, que se articulam e dão origem à subjetividade social. Esses sentidos se configuram interferindo no modo, por exemplo, como os sujeitos com dificuldades de 
aprendizagem produzem a sua subjetividade individual e sua identidade em relação a essa questão.

A ideia de produção destaca a ênfase que a categoria sujeito adquire nessa perspectiva teórica, ou seja, é ele que produz sentidos subjetivos, que se articulam em sua configuração subjetiva, a partir da relação com o contexto social, rompendo com a ideia de internalização das experiências, com base na relação direta entre causa-efeito. O sujeito é definido como sendo um indivíduo consciente, intencional, atual e interativo, possuindo maior responsabilidade dentro do espaço em que atua, não estando limitado a uma estrutura psíquica que o determina, sendo capaz de produzir (GONZÁLEZ REY, 2007a). Com isso, ele se organiza a partir da interação dialética, sendo subjetivamente configurado por um espaço social concreto e, ao mesmo tempo, sendo produtor de novas configurações subjetivas que caracterizarão a subjetividade social. Reafirma-se a existência do sujeito ativo dentro de um espaço, ou seja, o sujeito que age, sendo capaz de gerar diferentes subjetivações de acordo com as experiências vivenciadas nos mais variáveis contextos e relações em que se insere.

No contexto em saúde, o que muito se tem visto nas práticas, de acordo com González Rey (2011b), é que tanto na área médica como no sentido comum das pessoas, supõe-se que a cura se vincula diretamente ao medicamento ou aos procedimentos médicos. Com isso, adota-se uma atitude passiva em relação ao modo de vida e às potencialidades do próprio sujeito. A análise do histórico da profissão permite observar essas implicações na prática em TO, onde muitas ações atuais, baseadas no modelo biomédico, adquirem um lugar preponderante. Partindo desses pressupostos, este trabalho destaca a necessidade de se considerar as implicações da Teoria da Subjetividade de González Rey, no âmbito da Terapia Ocupacional, visto que o tema da subjetividade se manteve (e em alguns espaços ainda se mantém) desvalorizado e periférico. A partir disso, observa-se a necessidade de retomar as bases teóricas da profissão, que tem como foco o diversificado cotidiano das pessoas, a partir da compreensão da singularidade que o caracteriza.

Ao se considerar o conceito de configurações subjetivas nas práticas em saúde, é possível obter duas considerações importantes. A primeira consiste em superar a ideia de explicar um estado da pessoa vinculado diretamente à determinada atividade ou experiência concreta, sem considerar a dinâmica da subjetividade social, entre outros 
fatores. A segunda permite superar a influência de aspectos externos ao sujeito, sem considerar sua capacidade de gerar alternativas ao longo de sua experiência (GONZÁLEZ REY, 2011b). Além disso, o autor destaca que a configuração subjetiva, nesse contexto:

"permite identificar uma produção dominante de sentidos subjetivos, que não aparecem diretamente na queixa da pessoa e nem em sua rotina de ações, pois é um tecido simbólico-emocional complexo que aparece indiretamente nas expressões da pessoa e que está na base do tipo de emoções que prejudicam os sistemas somático-funcionais da pessoa" (GONZÁLEZ REY, 2011b, p.37).

O sujeito, nessa perspectiva, não se configura, portanto, como um "paciente", pois ele participa ativamente do seu processo de saúde, produzindo configurações subjetivas que interferem nesse contexto, assim como em outros espaços. A existência da complexa teia simbólico-emocional, que integra diferentes sentidos subjetivos, permite olhar para a pessoa além dos aspectos objetivos do tratamento, compreendendo a articulação dos sentidos provenientes de diversos contextos como elementos constituintes desse processo, assim como de sua aprendizagem. Além disso, permite a compreensão da articulação dos sentidos com diferentes momentos vividos, a partir da relação que eles estabelecem com o que é histórico e atual. Os sentidos se manifestam em situações concretas, como por exemplo, no campo terapêutico e dentro de sala de aula.

Dessa forma, no contexto terapêutico a criança com deficiência ou transtorno também tem a possibilidade de se constituir como um sujeito ativo que se posiciona perante seu tratamento. Entretanto, o que ocorre muitas vezes é que ela se torna estigmatizada por uma pretensa incapacidade, desconsiderando-se que seja capaz de produzir sentidos subjetivos perante o processo terapêutico e sua aprendizagem. Essa questão se reafirma também a partir da despreocupação de alguns profissionais da saúde em instruir ou esclarecer aos pacientes informações sobre a patologia e o tratamento, a fim de que eles se tornem sujeitos da doença, sendo capazes de se posicionarem perante essa situação. Com isso, muitas vezes, eles acabam não recebendo estímulos que os incentivem na produção subjetiva perante o processo saúde-doença, tornando-se “assujeitados” na situação.

Para González Rey (2007a) torna-se necessário compreender que as pessoas com deficiência e transtornos também vivenciam uma relação simbólico-emocional, gerando 
sentidos subjetivos em diversas situações. Dessa maneira, as características diagnósticas não são capazes de definir a singularidade dos indivíduos, visto que elas geralmente não expressam a historicidade e dinamicidade da constituição subjetiva de cada sujeito e, consequentemente, de seu desenvolvimento.

O desenvolvimento elaciona-se com as diversas configurações subjetivas provenientes da vivência de cada sujeito nos diferentes espaços, de acordo com sua organização e relações estabelecidas. Por consequência, apesar do biológico e do social constituírem a subjetividade, esta não se resume a nenhuma dessas duas instâncias isoladamente. Ela se organiza e funciona conforme a ação do sujeito, a partir de sua singularidade e emocionalidade, que são configuradas de acordo com sua história e com o momento atual. Para González Rey (2007a), o defeito não é analisado por si só, mas pela capacidade de produção da pessoa perante situações concretas, expressando-se subjetivamente na configuração de sentidos em uma teia simbólico-emocional. Logo, ao se observar situação atípica dentro da sala de aula ou na clínica, não é possível estabelecer uma relação direta entre ela e um fato externo ou uma característica diagnóstica. Em contraposição, é necessário compreender a existência de sentidos subjetivos que se configuram processualmente e historicamente na constituição de cada sujeito, em cada situação vivida.

O autor destaca sobre a existência de valores e recursos inerentes às pessoas que poderiam facilitar o desenvolvimento de alternativas, permitindo esses sujeitos se reposicionarem em relação à patologia. Porém,

"a ideologia dominante da sociedade de consumo
centrada no efeito rápido, na comodidade, na fuga
absoluta ao esforço e sacrifício, não oferece caminhos
institucionais para o desenvolvimento de novas formas
de viver que permitam à pessoa ser protagonista de
opções e não dependente de procedimentos e
aparências" (GONZÁLEZ REY, 2011b, p. 107).

Assim, a ideia dentro da perspectiva da Subjetividade é valorizar o sujeito no processo terapêutico além dos procedimentos e técnicas padronizadas. Propõe-se estimular o desenvolvimento de ações e práticas no contexto da saúde que facilite esse “outro", que não se configura como um paciente, “empreender novas opções, esclarecer 
posições próprias a partir de suas reflexões no espaço de relação com o profissional da saúde" (p. 107).

Esses pressupostos convergem com as propostas de alguns autores no campo da TO em relação à atuação da profissão no contexto educacional, com foco sobre intervenções atividades e relações do cotidiano, que pressupõem a valorização do sujeito que as realiza em detrimento de técnicas e procedimentos padronizados. A partir de um redirecionamento da prática baseada em normalização, volta-se para novas intervenções com olhar para o cotidiano do sujeito e as relações estabelecidas (JURDI, BRUNELLO, HONDA; 2004).

Conforme defende Galheigo (2003), é importante considerar o valor que a subjetividade e autonomia adquirem no cotidiano, representando algo singular, em detrimento de considerá-lo como simples repetição mecânica de ações. Ao olhar para esse cotidiano, é necessário olhar para o sujeito e para a singularidade que as atividades e relações adquirem para ele dentro de cada contexto. Desse modo, a proposta do presente trabalho articula-se com a Teoria da Subjetividade, visto que ela nos proporciona uma percepção da complexidade e dinamicidade que envolvem os processos de saúde-doença e da aprendizagem, a partir de sua processualidade, rompendo com as tradições hegemônicas da clínica. Essa perspectiva aponta para a importância de se considerar aspectos singulares dos sujeitos, sem desconsiderar o contexto institucional e social nos quais estão inseridos. Assim, o "paciente" de Terapia Ocupacional, nesse referencial teórico, assume uma dimensão social e histórica. Torna-se, pois, necessário olhar para além do diagnóstico, considerando a complexidade da dimensão subjetiva do sujeito e sua potencialidade de construir caminhos alternativos perante sua vida. Dessa forma, compreende-se a relevância de intervenções que valorizem a emergência de aspectos subjetivos, facilitando estratégias que permitam o desenvolvimento não de "pacientes", mas de sujeitos. 


\section{4-METODOLOGIA}

\subsection{Epistemologia Qualitativa}

Uma vez que o objetivo é identificar implicações da Teoria da Subjetividade para a prática em TO, tendo em vista os aspectos subjetivos dos sujeitos que enfrentam situações de dificuldades de aprendizagem, torna-se imperioso adotar a metodologia em conformidade com os princípios da Teoria, ou seja, a Epistemologia Qualitativa.

"A subjetividade é um sistema complexo de significações e sentidos subjetivos produzidos na vida cultural humana.” (GONZÁLEZ REY, 2002, p. 36). Porém, essa subjetividade não é um reflexo direto da cultura, ela se constitui na história de cada sujeito, tendo seu caráter histórico, processual e social. A partir dessa relação entre o histórico e atual, concretizadas nas produções de sentidos subjetivos, a categoria de sujeito ganha destaque dentro dessa perspectiva (González Rey, 2005a). Com isso, um dos princípios da Epistemologia Qualitativa, dentre outros mais, é a importância da singularidade, destacando-se nesse tipo de pesquisa, não a quantidade de sujeitos participantes, mas sim a qualidade de suas expressões.

Para González Rey (2002), a Epistemologia Qualitativa aparece como "um esforço na busca de formas diferentes de produção do conhecimento em psicologia que permitam a criação teórica acerca da realidade plurideterminada, diferenciada, irregular, interativa e histórica, que representa a subjetividade humana.” (p. 29). Segundo o autor, a Epistemologia Qualitativa permitiu na pesquisa científica uma reconstrução sobre a maneira de se produzir o conhecimento, que consequentemente gerou mudanças na relação do participante da pesquisa com o pesquisador. Partindo desse pressuposto, não se considera que haja uma verdade absoluta sobre um fato e que já esteja pré-determinado, no qual o pesquisador somente tem a função de "colher" dados e quantificá-los. Em contraposição, enfatiza-se a construção desse conhecimento a partir da compreensão de sistemas configuracionais dinâmicos, o que é facilitado por meio da interação dialógica entre pesquisador e sujeito da pesquisa. Perde-se a neutralidade do pesquisador, que passa a ser um sujeito subjetivamente envolvido no processo. Dessa forma, tem-se outro princípio dessa metodologia, segundo o autor: a concepção do conhecimento como uma produção construtivo-interpretativa. Não há constatações imediatas, o conhecimento é construído durante todo o processo, em que o pesquisador procura dar sentido às 
expressões do sujeito e interpretá-las constantemente. Tem-se, assim, um caráter ativo do pesquisador, que se posiciona a partir da construção e interpretação das informações.

Esse posicionamento favorece a metodologia baseada nas relações sociais, o que justifica outra característica metodológica: a produção do conhecimento possuindo um caráter interativo e dialógico. Parte-se da ideia de que, para se compreender fenômenos humanos complexos, deve-se enfatizar a importância das relações sociais. Com isso, a comunicação adquire um destaque fundamental, como sendo necessária para o estudo dos fenômenos humanos. Essa metodologia permite o estudo de fenômenos a partir da consideração da subjetividade como um sistema em desenvolvimento, e não com características determinadas a priori. Admitindo essa complexidade, com interferência de fatores culturais e sociais, é possível adotar novos olhares para determinadas situações e fenômenos, não sendo esses mais vistos como questões fragmentadas e descontextualizadas, como muito se observava na pesquisa quantitativa.

Segundo González Rey (2002, 2005b), a Epistemologia Qualitativa enfatiza o contexto singular em que ocorre cada experiência vivida. Portanto, investiga-se em vários cenários sociais, visto que a subjetividade se configura a partir de diferentes espaços, a fim de identificar indicadores que levem a compreender o fenômeno analisado. $\mathrm{O}$ desenvolvimento desses indicadores permite a elaboração de conceitos e categorias ao longo da pesquisa, que levam a construções teóricas sobre o fenômeno estudado, permitindo conhecer novas zonas de sentidos, as quais possibilitam o surgimento de novas categorias sobre o objeto estudado. A elaboração teórica nessa metodologia é um processo gradativo, ocorrendo ao longo de toda pesquisa, cujos dados e indicadores são ressignificados em diferentes momentos.

Ao utilizar essa metodologia para a compreensão de fenômenos como a subjetividade, pode-se analisar fenômenos que muitas vezes foram considerados de forma isolada e descontextualizada, como por exemplo, os aspectos subjetivos dos sujeitos que enfrentam situações de dificuldades de aprendizagem no processo de Terapia Ocupacional, que muitas vezes têm ficado obscurecidos. 


\subsection{Instrumentos}

González Rey (2005b) define os instrumentos na pesquisa qualitativa como "toda situação ou recurso que permite ao outro expressar-se no contexto de relação que caracteriza a pesquisa” (p. 42). Dessa forma, para o autor os instrumentos surgem não como estrutura rígida, baseada em estímulo-resposta, mas como um facilitador da expressão da pessoa, através do envolvimento emocional que permitirá a expressão dos sentidos subjetivos participantes do processo. Partindo dessa concepção metodológica, são utilizados vários instrumentos durante a pesquisa, assim como situações informais, que não são analisados de forma isolada, mas que mantém entre si uma relação dinâmica, formando um sistema de informação. Com isso, eles não seguem regras padronizadas e nem são todos definidos a priori.

Nesta pesquisa, foram utilizados os seguintes instrumentos: observações do atendimento em Terapia Ocupacional, sistemas conversacionais com alguns adolescentes, com a terapeuta ocupacional e com duas professoras. Elaboração de desenho, complemento de frases e "as três coisas", instrumento elaborado pela pesquisadora que surgiu no processo a fim de contribuir com os objetivos da pesquisa também foram realizados com todos os adolescentes. Além disso, alguns momentos informais não previstos também representaram contribuições para este trabalho.

\section{Observações do atendimento em Terapia Ocupacional}

A observação foi utilizada para o acompanhamento do processo terapêutico em TO, a fim de compreender como nesse espaço ocorria a manifestação de aspectos subjetivos e como se lidava com eles dentro do processo. Além disso, as observações permitiram um primeiro contato com os participantes da pesquisa, o que possibilitou ter uma primeira concepção sobre o comportamento e atitudes de alguns adolescentes, o que contribuiu para posteriormente escolhermos alguns para a continuidade do desenvolvimento da pesquisa.

\section{Sistemas conversacionais}

Os sistemas conversacionais possibilitam quebrar a relação hierárquica que prevalece nas pesquisas tradicionais entre pesquisador-pesquisado, colocando ambos em situação dialógica e relacional, rompendo com o tradicional padrão de pergunta e resposta. 
González Rey (2005b) destaca que no processo de conversação é facilitada a emergência de sentidos subjetivos, através da integração das experiências, dúvidas e tensões, tanto do pesquisador como do participante, que adquirem a postura ativa na pesquisa. "É no processo de comunicação que o outro se envolve em suas reflexões e emoções sobre os temas que vão aparecendo" (González Rey, 2005, p. 47). Nesta pesquisa, os sistemas conversacionais foram utilizados com três adolescentes, a fim de compreender aspectos da dinâmica subjetiva deles. Esse instrumento também foi realizado com a terapeuta ocupacional, com objetivo de compreender maiores questões sobre a prática da profissional e aspectos do espaço terapêutico. E por fim, o utilizamos com duas professoras da escola, com objetivo de compreender as relações, experiências e práticas no espaço escolar.

\section{Complemento de frases}

"É um instrumento que nos apresenta indutores curtos a serem preenchidos pela pessoa que responde" (González Rey, 2005b, p.57). Os indutores são formulados conforme os objetivos do pesquisador, podendo ser referentes a pessoas, experiências, atividades. Dessa maneira, elaboramos várias frases, a partir de questões interessantes observadas no grupo terapêutico, relacionadas à escola, família, amigos, o grupo terapêutico, que funcionaram como impulsos para explorar a organização subjetiva dos adolescentes e compreender sua singularidade. Utilizamos o instrumento com todos os participantes do grupo, o que nos possibilitou identificar questões da dinâmica subjetiva, que foram mais aprofundadas durante o sistema conversacional. A articulação entre os dois instrumentos e o relacionamento entre a pesquisadora e os adolescentes possibilitaram momentos de diálogo e processos reflexivos.

\section{Elaboração de desenhos}

Propôs-se a elaboração de desenho para os adolescentes com o tema "O mundo ideal", a fim de que pudesse ser uma forma alternativa de expressão simbólica, além das palavras (González Rey, 2005b). Assim, essa estratégia representou outro elemento que contribuiu para o aprofundamento de questões, possibilitando compreender a dinâmica subjetiva de alguns adolescentes. 


\section{"As três coisas"}

Esse foi um instrumento escrito elaborado pela pesquisadora, que consistiu em alguns blocos de temas sobre os quais o participante escrevia três palavras ou frases curtas que estavam relacionadas a eles. Por exemplo: "três medos", "três pessoas importantes", "três mudanças que faria na escola", entre outros. O instrumento teve como objetivo ser um caminho alternativo, a fim de provocar o aparecimento de sentidos subjetivos relacionados a determinados assuntos e questões, para que pudessem ser explorados, a fim de contribuir para a elaboração de hipóteses interpretativas sobre as produções subjetivas dos participantes.

\section{Momentos informais}

O vínculo construído com alguns participantes possibilitou que momentos informais se constituíssem como espaços da pesquisa, a partir de sua importância para a construção teórica. Esses momentos foram preenchidos por conversas informais com alguns adolescentes, antes ou após as sessões grupais. No início, houve uma tentativa de aproximação com os adolescentes nesses momentos, a fim de construir um vínculo, contudo, nos últimos encontros, eles estavam me procurando para conversar sobre diversos assuntos, principalmente sobre situações da escola e sobre a família, o que algumas vezes, tornou-se bastante delicado. Essas conversas informais não foram todas registradas, estando além dos momentos previstos da pesquisa, porém contribuíram para a construção do modelo teórico das configurações subjetivas dos adolescentes.

\subsection{Locais da pesquisa e construção do cenário de pesquisa}

A pesquisa foi realizada em dois contextos de atuação: um espaço terapêutico de Terapia Ocupacional e uma escola pública de ensino fundamental, ambos localizados em Brasília-DF. A escolha dos locais partiu da premissa de, primeiramente, encontrar um contexto onde houvesse uma prática em TO que se articulasse com o contexto escolar, para depois selecionar a escola, porém, durante essa busca, encontramos algumas barreiras. Dentre os espaços da Secretaria de Saúde que ofereciam Terapia Ocupacional, em sua maioria não foi observada, no processo terapêutico, articulação significativa com a escola, apesar de serem atuações no contexto da infância/adolescência. Por outro lado, alguns serviços foram descartados devido às restrições institucionais e/ou profissionais. 
Por fim, encontramos um contexto terapêutico que estava sendo estruturado e organizado a partir da articulação entre o espaço escolar e um espaço de saúde, o que poderia contemplar os objetivos da pesquisa.

Dessa forma, encontramos uma pediatra de um espaço de atenção primária em saúde, pertencente à Secretaria de Saúde do DF, que em parceria com uma escola pública próxima a região e com uma terapeuta ocupacional, propôs um projeto de atendimento grupal em Terapia Ocupacional para alguns adolescentes com TDAH (Transtorno do Déficit de atenção e hiperatividade), que frequentavam uma mesma escola. A pediatra constantemente realizava articulações com esse espaço escolar, a partir de diversos projetos e parcerias. A ideia do projeto em Terapia Ocupacional surgiu inicialmente a partir de uma primeira experiência desse grupo, que foi realizada há alguns anos durante um estágio obrigatório do curso de TO nesse espaço de saúde.

A terapeuta ocupacional responsável pelo grupo, Thaís ${ }^{2}$, atualmente funcionária da Secretária de Saúde do DF, lotada em um Hospital Regional, também participou da primeira experiência do grupo como estagiária, juntamente com outra aluna. Após alguns anos, a pediatra decidiu retomar esse projeto, devido às contribuições significativas que ele proporcionou na primeira vez que foi executado. Como esse espaço de saúde não tem o profissional de Terapia Ocupacional, ela solicitou ao Hospital que, Thaís, por já ter participado do grupo na primeira vez, fosse remanejada exclusivamente para realizar esse atendimento grupal semanalmente. Assim, a partir dessa articulação entre a pediatra, a terapeuta e a professora responsável pela sala de recursos, $\mathrm{Carla}^{2}$, o projeto do grupo terapêutico em TO para adolescentes com TDAH, que frequentava essa escola, foi retomado no mês de Março de 2016.

A primeira participação nesse espaço coincidiu com o dia em que ele teve início, o que facilitou a entrada no campo e a construção de vínculos com os adolescentes. Participei de oito encontros que aconteceram no período de Março a Junho de $2016^{3}$, tendo após esse período um breve recesso devido às férias escolares, com retorno dos atendimentos em agosto. Durante os oito encontros, buscou-se construir uma sutil

\footnotetext{
${ }^{2}$ Nomes fictícios utilizados a fim de manter o sigilo dos participantes.

3 Os encontros não aconteceram conforme a frequência prevista devido a contratempos pessoais da terapeuta, do espaço físico e de algumas atividades escolares.
} 
aproximação com os adolescentes a partir da construção de vínculos, inicialmente através da observação e nos últimos meses com pequenas interferências nas atividades, além de conversas com eles em alguns momentos informais, antes ou depois de cada encontro. Além disso, por três vezes e em ocasiões e momentos distintos encontrei-me por coincidência em outros locais, com duas adolescentes do grupo, que demonstraram alegria e entusiasmo em me ver, inclusive me abraçando e comentando em outros momentos da pesquisa sobre esses dias. Dessa maneira, a partir da formação de vínculos com os adolescentes começamos a construir o cenário da pesquisa, sendo esse espaço social responsável por possibilitar o envolvimento subjetivo dos colaboradores com a pesquisa (González Rey, 2005b).

No mês de Junho/2016, foram realizados os primeiros contatos com o espaço escolar, a fim de conhecer a estrutura e conversarmos sobre a pesquisa. No entanto, o contato com os adolescentes nesse espaço e com alguns profissionais ocorreram durante os meses de Agosto a Novembro/2016, com aproximadamente 07 visitas alternadas nesse espaço durante esse período, com duração de aproximadamente 1 hora e 30 minutos cada uma.

A escola em que foi realizada a pesquisa é pública e de ensino fundamental, sobresponsabilidade da Secretaria de Educação do DF, localizada em Brasília-DF. A escola atende aproximadamente 910 alunos, divididos em um total de 14 turmas de $7^{\circ}$ e $8^{\circ}$ anos no período matutino, sendo onze do sistema regular e três de aceleração, com 14 turmas no período vespertino, dos $6^{\circ}$ e outras também do $7^{\circ}$ ano. A maioria dos alunos atendidos pela escola reside em quadras próximas, ou na mesma região administrativa, porém, uma quantidade significativa reside no entorno do DF. A escola atende alunos com necessidades educacionais especiais que frequentam, além da sala de aula, a sala de recursos pedagógicos da escola, no turno contrário às aulas, duas ou três vezes por semana, durante um período de 2 horas por dia. No ano de 2016, a quantidade total de alunos atendidos nesse espaço foi em média 42, sendo 19 com diagnóstico de TDAH.

As salas de recursos são espaços dentro das escolas públicas regulares de ensino, que tem como objetivo, segundo a Portaria Ministerial $n^{\circ}$ 13/2007, apoiar e organizar o Atendimento Educacional Especializado (AEE) nos sistemas públicos de ensino, e assim contribuir para o processo de inclusão nas classes regulares. Segundo a resolução CNE/CEB (Conselho Nacional de Educação/Câmera de Educação Básica) no 4/2009, os 
alunos atendidos pelo AEE são divididos em três grupos: alunos com tipos de deficiência, transtorno do desenvolvimento e altas habilidades/superdotação. O TDAH, assim como outros transtornos funcionais específicos da aprendizagem, como a dislexia, não se enquadram em nenhum dos grupos atendidos pelo AEE, dessa maneira, não está previsto legalmente o atendimento dos alunos diagnosticados com esses transtornos nas salas de recursos. Apesar disso, a professora responsável por esse espaço oferece um suporte para esses alunos, o que encontra relação com elementos da história de vida da profissional, como por exemplo, ela ter um filho adolescente diagnosticado com TDAH.

As visitas na escola ocorreram em alguns dias no período matutino e em outros no vespertino, a fim de contemplar os diferentes turnos escolares dos alunos. Nesses encontros realizamos alguns instrumentos da pesquisa com praticamente todos os participantes do grupo, incluindo sistemas conversacionais com três adolescentes e com duas professoras da escola.

\subsection{Participantes}

No primeiro momento, durante a observação do grupo terapêutico, todos os adolescentes que frequentavam esse espaço constituíram-se como colaboradores da pesquisa: Alice, George, Yara, Olívia, Iago, Saulo, Thales e Mauro4. Além disso, todos eles realizaram os instrumentos: Completamento de frases, Elaboração de desenho e "As três coisas", exceto Iago que se recusou a participar dessas atividades. Após os momentos de observação no grupo e do preenchimento desses instrumentos, selecionamos três adolescentes para com eles realizar os sistemas conversacionais, a fim de um melhor aprofundamento em questões específicas. Estes três foram escolhidos a partir de algumas situações peculiares ocorridas durante as atividades no grupo, nas quais eles se destacavam, fossem pelas expressões, verbais ou não, e pelas ações. Além disso, foram observadas questões interessantes nos instrumentos que eles preencheram, as quais despertaram um maior interesse para explorá-las. Após ter escolhido esses três participantes, e ter comunicado a escolha para a professora da sala de recursos, ela relatou

\footnotetext{
${ }^{4}$ Nomes fictícios utilizados a fim de manter o sigilo dos participantes.
} 
que achou interessante os que haviam sido escolhidos, pois eles eram os que mais "chamavam atenção" na escola, devido aos relacionamentos, muitas vezes conflituosos, com os professores, e também atitudes e comportamentos deles. Dessa forma, selecionamos os três adolescentes, os quais serão conhecidos com maiores detalhes ao longo do trabalho: Yara, George e Alice. Por ser uma pesquisa realizada com menores de idade, solicitou-se a participação de todos os adolescentes aos pais/responsáveis, através da assinatura do Termo de Consentimento Livre Esclarecido (TCLE) (APÊNDICE E).

Outros colaboradores da pesquisa foram a Terapeuta Ocupacional responsável pelo grupo, Thaís, a professora responsável pela sala de recursos, Carla, e uma professora da disciplina de Educação Artística, Camila ${ }^{5}$. Com esses profissionais foram realizados sistemas conversacionais.

${ }^{5}$ Nomes fictícios utilizados a fim de manter o sigilo dos participantes. 


\section{5-PRODUÇÃO TEÓRICA}

O processo construtivo interpretativo foi organizado em três eixos temáticos a fim de facilitar a compreensão de como ocorreu a produção teórica de acordo com os objetivos previstos. No primeiro eixo, apresentamos a análise de dois contextos em que foi realizada a pesquisa: o grupo terapêutico, que ganhou um maior destaque tendo em vista os objetivos da pesquisa, e breve análise das relações no espaço escolar. O segundo eixo tem como foco a história de vida, relações e cotidiano dos três adolescentes que foram escolhidos ao longo da pesquisa. E por fim, no terceiro eixo, apresentamos a análise integrativa dos contextos e dos três casos analisados e suas implicações para o processo terapêutico em TO, com base nas contribuições da Teoria da Subjetividade.

\subsection{Grupo}

As reuniões do grupo eram realizadas uma vez por semana, às quintas-feiras, pela manhã, às 10h, em uma sala do Centro de Saúde da região, com duração de aproximadamente uma hora e trinta minutos. O total previsto de participantes seriam 14 adolescentes, porém alguns não compareceram a nenhum dia, e outros faltavam ocasionalmente. Com isso, participaram dos encontros, em média 08 adolescentes a cada dia, entre meninos e meninas: Alice, George, Yara, Olívia, Iago, Saulo, Thales e Mauro. Todos os adolescentes do grupo frequentavam a mesma escola, a maioria em séries e turmas separadas, porém, entre eles já se conheciam, pois todos participavam do atendimento da Sala de Recursos pedagógicos da escola. O grupo era coordenado pela terapeuta ocupacional, Thaís, e durante o período de março a julho de 2016 teve o auxílio de três estagiárias em TO.

A estrutura básica de funcionamento do grupo consistiu em diversificadas atividades terapêuticas propostas em cada encontro, em média duas ou três em cada sessão. Ao final de cada atividade, a terapeuta Thaís, propunha uma reflexão coletiva sobre os benefícios proporcionados por elas, estando relacionados com o desenvolvimento e estímulo de funções e componentes de desempenho que geralmente são afetados pelo TDAH, como: atenção, concentração, memória, raciocínio, 
coordenação motora, entre outros. Nesse espaço, primeiramente, ela permitia que eles emitissem opinião sobre os objetivos de cada atividade, o que favorecia um momento de expressão e comunicação. Após provocar o posicionamento dos participantes, a partir de reflexões sobre as atividades, ela explicava sobre os componentes de desempenho que elas desenvolviam e os relacionava com a importância da utilização deles em outros contextos e situações do cotidiano, principalmente no espaço escolar e suas relações com a aprendizagem. Assim, apesar dos espaços de expressão favorecidos pela profissional, a organização do processo terapêutico com base em uma concepção organicista, às vezes, impedia que fossem aprofundadas e exploradas outras questões contextuais e relacionais que surgiam constantemente de forma espontânea no discurso deles. Por exemplo, ao final da "Atividade das Histórias" *, a terapeuta iniciou a reflexão com eles sobre os objetivos proporcionados por essa atividade.

\author{
TO: Então, teve lógica? Teve história? \\ George: Sim, do beijo, da grávida. \\ TO: Mas estava bagunçado \\ Yara. : Mas foi uma história. \\ George: Começou com Era uma vez, teve sim. \\ TO: Porque isso aconteceu? \\ George: Quem escreveu "pitzarria"? \\ TO: Porque isso aconteceu? \\ George: Somos diferentes. \\ Yara: Preguiça. \\ Olívia: Não entende letras. \\ Yara: Não me zoa. \\ TO: Será falta de atenção? \\ Yara: Tô com fome. \\ Igor: Tô na "broca".
}

Apesar de os adolescentes expressarem suas opiniões a partir das perguntas reflexivas feitas pela profissional, o que eles relatavam parecia passar despercebido pela terapeuta, provavelmente porque não era o que ela esperava ouvir. Tal situação pode indicar a atuação centrada em uma perspectiva técnica. Da mesma maneira, observa-se que em determinado momento os adolescentes passaram a ignorar o que a TO estava questionando, ou seja, outras questões relevantes se manifestavam naquela ação concreta, o que, muitas vezes, pode ser interpretado pela profissional como falta de atenção, relacionando ao diagnóstico de TDAH. González Rey (2007a, p. 167) aponta que “[...] no sentido subjetivo dos atos do sujeito em um espaço social concreto estão contidos 
processos e consequências de outros espaços sociais que lhe afetam de forma simultânea". A partir desse momento, podemos notar a complexidade que envolve a situação, havendo uma digressão dos participantes da sessão, quando eles fazem comentários em uma direção diferente daquela que a TO tinha em mente. Nesses comentários podemos perceber uma manifestação subjetiva dos adolescentes no processo em TO, a partir de uma atividade, mas estando além dos objetivos previstos para ela.

Essa situação nos faz refletir sobre uma contradição do que seria uma atuação terapêutica com foco nas características do diagnóstico, em detrimento de uma que valorize o aparecimento de questões subjetivas. A falta de sentido da história, produto final da atividade, não se relacionava diretamente com a falta de atenção, conforme apontado pela terapeuta. Porém, compreendemos que a atividade, por ser uma produção livre, estimulou processos criativos e de manifestação da expressão do sujeito, que aparecem em produções singulares, que caracterizam o texto final da atividade. Conforme observamos na expressão dita por um deles, a história não teve sentido, pois "somos diferentes" (George, grupo de TO).

Se por um lado a profissional, muitas vezes, previa e esperava determinadas respostas deles em relação aos objetivos das atividades, por outro lado, ela também tinha uma postura flexível, principalmente em momentos que não tinham relação direta com a parte técnica da atividade. A TO parecia reconhecer a importância da existência de momentos, além das situações formais das atividades, nos quais eles pudessem se expressar e emitir opiniões. Desde o primeiro encontro, ela rompeu com um clima formal de atendimento, solicitando que eles sugerissem como poderia se estruturar os atendimentos, incluindo as atividades de interesse deles.

TO: "Vocês podem trazer outras atividades para realizarmos aqui. Vamos trabalhar outras questões que vocês trazem de acordo com as atividades".

Olívia: "Sei fazer dobradura".

TO: "Que bom, Olívia, pode trazer um dia se você quiser".

A terapeuta também relatou que o grupo seria um espaço de discussão e debate, no qual eles poderiam se manifestar sobre assuntos de interesse deles ou que os incomodava. Durante todos os encontros, situações como foram observadas na “Atividade das Histórias", que envolviam o aparecimento de questões diversas sobre 
esses adolescentes, surgiram de maneira recorrente, a partir de estímulos propiciados pelas atividades ou de forma aleatória. A maioria desses momentos, principalmente quando não se relacionava com a análise técnica dos objetivos das atividades, era valorizada pela terapeuta, que parecia ter a disponibilidade e a flexibilidade como recursos conscientes pertencentes à sua conduta da profissional.

"Acho que era o espaço que eles encontraram pra falar já que na escola, pelo menos segundo a Carla*, os professores tinham muita dificuldade em compreender o que é TDAH e acho que na escola eles não têm esse espaço pra falar, acho que o espaço que eles acharam foi no grupo. E eles falavam de tudo, e a gente tinha que mudar o foco da atividade, e não trabalhar só os componentes cognitivos que era a proposta. Acabou trabalhando outras questões que vão além (Thaís, sistema conversacional)."

A profissional estimulou a criação de um ambiente que valorizava a participação dos adolescentes no processo terapêutico, diminuindo a relação hierárquica entre profissional-paciente, o que favoreceu um espaço para criação de diferentes possibilidades de desenvolvimento. Essa postura contribuiu para que ela se aproximasse e passasse a valorizar no processo terapêutico outras questões relacionadas ao cotidiano desses adolescentes, através de ações de acolhimento, atenção e escuta. Por exemplo, enquanto estava acontecendo o encontro, Alice estava mexendo no celular já fazia algum tempo, e a TO em vez de recriminar a atitude procurou compreender o que ela estava fazendo e a partir disso iniciou uma discussão coletiva sobre redes sociais, na qual eles participaram ativamente. Em outro momento, a partir de uma conversa entre eles, iniciou um debate sobre as gírias que eles utilizavam no dia a dia. Além das problematizações surgidas no discurso direto dos adolescentes, em alguns momentos, a profissional foi capaz de perceber inquietações através de diferentes manifestações, como tom de voz, maneira de falar e expressões faciais, e assim, buscou compreender os motivos emergentes. Durante uma situação, a TO havia percebido que Yara repetia por várias vezes que estava nervosa e estressada, além de proferir palavras de baixo calão e responder rispidamente aos colegas. Ao final do encontro, ela pediu para conversar individualmente com a adolescente para saber o que estava acontecendo.

As atitudes possibilitaram a criação de vínculos entre a profissional e os participantes, permitindo a caracterização de um espaço no qual eles se sentiram 
confortáveis para se expressarem e refletirem sobre diversos contextos e situações do cotidiano deles, em que diversas vezes não encontravam oportunidade e local para isso. Os adolescentes retratavam diversas questões de forma espontânea, aleatoriamente ou impulsionados pelas atividades, tais como: escola, professores e colegas, família, relacionamentos, situações e conflitos vivenciados no dia a dia, situações de preconceito e violência, características deles, o que gostavam de fazer, entre outros. À medida que essas questões iam emergindo, a TO propiciava um espaço para que elas fossem mais exploradas, instigando alguns questionamentos a fim de que eles se expressassem. Ela comenta:

"E também muito do que eu fazia aqui no grupo, era devolver pra eles. Então eles faziam uma pergunta e eu devolvia a pergunta para eles. E às vezes eu fazia a mesma pergunta pra todos e cada um me respondia da forma que eles achavam que tava certo, da forma como eles viam a situação. Porque acho que realmente, cada um é um [...] (Thaís, sistema conversacional)".

Essa questão sugere uma flexibilidade do processo terapêutico e a desconstrução de procedimentos e técnicas universais, a partir da valorização da singularidade. Assim, apesar de existir um planejamento para cada encontro, Thaís estimulava momentos espontâneos, os quais possibilitavam que eles se expressassem. Esse espaço era concretizado em alguns momentos previamente estabelecidos, como no início de cada encontro, quando ela perguntava a todos como tinha sido a semana e eles relatavam principalmente sobre a família e sobre a escola, e também, aleatoriamente, de acordo com temas que surgiam durante os encontros. Por exemplo, em determinada situação, impulsionado por uma atividade, surgiu o assunto de agressões físicas deles em relação a outras pessoas, iniciado por Alice. Como eles demonstraram interesse em relação ao tema, a TO incentivou para que todos pudessem comentar sobre o assunto. Após a maioria ter relatado diversas experiências, a profissional realizou pequenos questionamentos reflexivos, relatando que, apesar de não ser algo planejado, discutiriam sobre esse assunto, pois o espaço do grupo também tinha como objetivo abordar questões que fossem do interesse deles. Outro exemplo da flexibilidade do processo terapêutico e como esse aspecto poderia favorecer o aparecimento do sujeito foi o lanche coletivo organizado pelos próprios adolescentes. Durante vários encontros, eles falavam sobre comidas e que estavam com fome, então, propuseram que tivesse um momento de descontração em um 
encontro, onde todos levassem algo para partilhar. A profissional aceitou a proposta, porém, sugeriu que eles organizassem essa atividade, criando um espaço em que foi valorizada a ideia trazida por eles, possibilitando que os participantes pudessem se posicionar e conduzir o momento.

Além desses momentos, houve situações inesperadas ocorridas durante as reuniões, devido a pequenos conflitos ocasionados pelas atividades ou temas polêmicos que algum deles relatava. A terapeuta aproveitava essas intercorrências para estimular um espaço de discussão, possibilitando que eles se expressassem sobre o assunto e encontrassem solução para algum conflito. A maioria dessas situações foi motivada por questões de jogo, relacionadas principalmente ao espírito de competição. Nesses momentos, Thaís interrompia a atividade e iniciava um espaço para que eles se expressassem e tentassem solucionar os conflitos, não a partir de advertência ou imposição, mas a partir de um estímulo à reflexão. Durante o jogo Lince ${ }^{6}$, por exemplo, Olívia parou de jogar e saiu triste para um canto da sala, disse que durante a brincadeira tinham machucado o dedo dela. Alguns falaram que isso era "criancice" da adolescente. Enquanto a TO discutia sobre respeito e a convivência em grupo com os outros participantes, a estagiária saiu da sala com a adolescente para conversar em particular. Após as duas retornarem, a estagiária fez alguns questionamentos para Saulo e Iago, sobre o acontecido:

Est.: Saulo, você apertou o dedo dela?

Saulo: Sim.

Est.: É certo isso?

Saulo: Não, desculpa.

Est.: Iago, você caçoou dela?

Iago: Sim.

Est.: É certo?

Iago: Não.

Iago pediu desculpas para Olívia, que retornou para o jogo. Em outro momento, após essa situação e durante essa mesma atividade, ocorreram discussões sobre quem estava acertando primeiro, em cada rodada. Em determinada partida, a profissional e as

${ }^{6}$ Jogo de tabuleiro. A terapeuta escolhia aleatoriamente uma cartela com uma figura, e ao mesmo tempo, os adolescentes tentavam encontrar o desenho dessa figura no tabuleiro, quem encontrasse primeiro colocava o dedo no local e ganhava a partida. 
estagiárias pediram para eles decidirem juntos sobre quem tinha acertado primeiro. Após algum tempo, eles começaram a formar uma opinião coletiva sobre quem estava acertando. A partir dessa postura, e por terem entrado em consenso sem divergências, a estagiária elogiou-os ao final do encontro. Esse reconhecimento despertou grande alegria, que se manifestou através das palmas que eles bateram, como forma de parabenizá-los pela atitude que tiveram. Provavelmente essa situação pode ilustrar que a felicidade deles estava relacionada com um desejo de reconhecimento e de mostrarem que eram capazes de tomarem uma atitude "correta" sozinhos. Após esse dia, ao longo dos encontros, alguns conflitos passaram a ser solucionados por iniciativas deles, não sendo necessárias as reflexões iniciais da TO. Outro exemplo foi em um encontro posterior quando George, acidentalmente, também durante uma brincadeira machucou o dedo da Olívia, e tomou a iniciativa de pedir desculpas para ela perante todo grupo. Nesses momentos, eles se tornavam sujeitos de suas ações, por iniciativa própria, sem palavras que os estimulassem a tomar determinadas atitudes consideradas "corretas". A subjetividade social desse espaço estava em movimento e favorecia o aparecimento da condição de sujeito em algumas situações, o que nos aponta para a relação entre a subjetividade social e individual nos processos de subjetivação. González Rey (2012) destaca sobre a constituição da subjetividade como sistema complexo a partir do inter-relacionamento e reciprocidade estabelecida entre os níveis individual e social, em que constantemente um é constituído pelo outro. Isso pôde ser percebido nesses momentos, pois demonstravam novos comportamentos e processos relacionais no grupo.

A flexibilização do processo terapêutico parecia estar relacionado com o reconhecimento e sensibilidade que a terapeuta também desenvolvia em relação ao grupo, em torno do que se organizava sua atuação profissional, como aparece em seu depoimento:

"[...] Só que eu percebi que esse grupo foi mais difícil do que os primeiros, as características dos alunos, eles eram mais agitados tinham outras questões mais evidentes e por várias vezes tivemos que adaptar as atividades ou pegar a maior parte do encontro pra falar de outras questões, né? Desviar o foco da atividade que a gente tinha. Então por várias vezes a gente teve que se adaptar por causa da demanda deles. Isso foi também uma diferença que eu percebi de um grupo pro outro né? Que mudou muito a experiência [...] (Thaís, sistema conversacional)." 
Apesar de a profissional ter conhecimento sobre questões teóricas para conduzir um grupo terapêutico, assim como o fato de ter tido outras experiências, pode-se inferir que a dificuldade tenha aparecido nessa prática específica devido às características do grupo. Assim, percebe-se que previamente a terapeuta não havia planejado alguns dos momentos de debate e discussão, principalmente quando eram iniciados pelos adolescentes, entretanto a situação prática sinalizou a necessidade de flexibilização e adaptação do planejamento terapêutico, o que a levou a se reposicionar nesse processo. González Rey (2011a) faz uma crítica a profissionais que utilizam fundamentos teóricos e metodológicos que enrijecem a prática, sendo necessário ter autenticidade e criatividade nesse processo, de acordo com os aspectos singulares que o constituem. Desse modo, os embasamentos teóricos e metodológicos que orientam a formação profissional, assim como outras experiências em um mesmo contexto de atuação, são importantes para a constituição do processo terapêutico, mas não podem ser algo que enquadre a atuação profissional.

A flexibilização da prática e a valorização da singularidade, por parte da terapeuta, também se manifestavam no tempo dedicado aos espaços coletivos de discussão em detrimento aos momentos técnicos das atividades. Essa ação pode indicar um reconhecimento da profissional sobre a relevância que os aspectos subjetivos adquirem na prática terapêutica.

"Então a gente acaba olhando pra ele em todos os contextos, então acho que igual eu disse, não é o menino com TDAH, tem um contexto por trás, um contexto familiar, escolar, social, sociocultural [...] (Thaís, sistema conversacional)."

O discurso e algumas atitudes da TO indicavam ações de flexibilidade, escuta e acolhimento, a partir do reconhecimento de que muitos problemas que os adolescentes expressavam não tinha relação direta com o TDAH, tendo outras gêneses contextuais. Porém, apesar disso, a atuação terapêutica com vistas a promover mudanças ainda estava centrada nos aspectos relacionados ao transtorno, por exemplo, à falta de atenção.

Ao analisarmos determinadas questões, percebemos que a atuação da profissional com objetivo de promover soluções e mudanças tinha como foco a relação entre os instrumentos terapêuticos e a possibilidade deles estimularem o desenvolvimento de aspectos relacionados às questões motoras, psicológicas e cognitivas. Ela parecia, então, 
não reconhecer em sua prática a capacidade de solução para esses problemas a partir das potencialidades dos adolescentes, ao serem sujeitos de suas vidas e conduzir os processos de mudança. A profissional acabava depositando as possibilidades de transformação a algo externo a eles, seja em procedimentos ou no contexto. Dessa forma, observamos que as ações da profissional em relação à flexibilidade terapêutica e valorização da participação dos adolescentes, que representavam momentos significativos para o aparecimento de questões subjetivas, manifestavam-se em ocasiões informais, principalmente quando não tinha relação com os aspectos técnicos e formais do processo terapêutico, como por exemplo, a análise dos benefícios das atividades. Ao realizar essa análise técnica, apesar de a profissional promover um debate coletivo e fazer relações com questões e situações mais amplas do cotidiano, iniciando discussões temáticas e espaços de expressão, limitava os benefícios da atividade a aspectos pontuais e de origem orgânica.

Com isso, embora as atividades favorecessem o aparecimento de aspectos subjetivos, eram as características do TDAH (ex: falta de atenção) que se sobressaíam como foco de sua atuação profissional e se manifestavam na análise dos objetivos terapêutico das atividades. Algumas vezes, por exemplo, quando os alunos estavam dispersos, querendo falar sobre vários assuntos aleatórios, ela redirecionava para a atividade, considerando que eles estavam se distraindo facilmente devido às características orgânicas do transtorno, como a falta de atenção. Os aspectos contextuais e relacionais da vida dos adolescentes não tinham tanta ênfase como recursos que pudessem contribuir para o processo terapêutico. Dessa forma, o foco da mudança estava nos instrumentos e em estratégias terapêuticas, e não em recursos dos próprios sujeitos. A terapeuta favorecia o espaço para que os sujeitos pudessem aparecer, contudo ainda estava concentrada na valorização de instrumentos e procedimentos para o "sucesso" do processo terapêutico. Esse aspecto pôde também ser observado a partir do relato de Thaís:

"Acho que a gente tem que trabalhar com o que é significativo pra eles [...] Esse também é um dos diferenciais da TO, trabalhamos muito com a questão de interesse. Então, o que o paciente quer fazer, o que ele pode fazer e de que forma a gente pode ajudar ele a fazer. Então acho que é isso mesmo, de considerar o que é importante e saber dosar, o que é importante, e o que ele quer fazer, não só pra ele, mas para o andamento da terapia." 
Nesse discurso, podemos observar que apesar dela perceber a necessidade de trazer o interesse como foco no processo terapêutico, ela enfatiza também o "andamento da terapia", compreendendo a importância depositada em aspectos formais. Além disso, observamos a vinculação a causas externas como responsáveis pelo "sucesso" terapêutico com foco nos procedimentos e na atuação profissional.

“[...] Então são coisas que o grupo não iria resolver, acho que o que eu pude ajudar foi positivo, mas eles têm demandas muitos maiores que ultrapassam o TDAH, e isso a gente não ia conseguir resolver (Thaís, sistema conversacional)."

Pode-se inferir que a capacidade de contribuição da terapeuta nesse processo estava restrita devido aos limites de sua atuação profissional, compreendendo não ser de sua competência algumas intervenções. Dessa forma, apesar de reconhecer a relevância das questões além do diagnóstico, ela se eximia da responsabilidade como profissional nesse processo, sendo mais uma questão que indica a valorização dos recursos e técnicas terapêuticas em detrimento da capacidade do sujeito. Em um dado momento, ela relatou que não conseguiria resolver determinados conflitos ou questões que eles abordavam e, diante disso, o seu posicionamento era: "eu tinha que acalmar os ânimos". A profissional acredita que essa dificuldade em solucionar alguns problemas ocorreu porque ela precisava do apoio da rede de saúde, ou seja, a articulação com outros serviços, principalmente com o serviço social. Essa era uma barreira, pois, segundo a profissional, ela não era servidora efetiva do Centro de Saúde, mas a sua instituição de origem era o Hospital Regional, por isso havia certas restrições na articulação com outros profissionais. Ainda complementou dizendo que uma das maiores barreiras que ela encontra atualmente como profissional é a dificuldade de encaminhamentos e articulações com outros setores, o que traz implicações para o trabalho terapêutico. González Rey (2011b) destaca que a burocracia dos processos institucionais atuais acaba desvalorizando as ações das pessoas, tornando-as instrumentos dos procedimentos e não alternativa reflexiva perante eles. Essa delegação de responsabilidades evidencia que ela também não se assumia como sujeito nesse processo em relação aos adolescentes do grupo terapêutico, depositando limitações em sua atuação com base em recursos externos a ela e aos participantes. O autor (2007a) destaca que o profissional também deve se assumir como sujeito do processo, a partir de um envolvimento em que ele também se implique e se responsabilize por esse "outro". 
Além disso, a ênfase nos procedimentos e em aspectos pontuais de origem orgânica também refletia quando propunha estratégias específicas para lidar com as dificuldades de aprendizagem. Em alguns discursos, por exemplo, a terapeuta relacionava o lugar em que eles sentavam em sala de aula à facilidade de prestar atenção. Dessa forma, é possível afirmar que as contribuições da Teoria na Subjetividade nos permite romper com essa concepção linear da aprendizagem, compreendendo esse processo como produção subjetiva singular, que se relaciona com as configurações subjetivas da pessoa que emergem nessa experiência concreta (González Rey, 2007a). Por consequência, no processo terapêutico de enfrentamento das dificuldades de aprendizagem, é necessário compreender as produções subjetivas do sujeito e suas relações com a aprendizagem, sendo os recursos de mudança perante essa situação inerente a eles, e não técnicas ou procedimentos padrões.

Propomos alguns tópicos a fim de destacar algumas questões a partir da análise do grupo, são eles:

1) O ambiente do grupo e espaços de expressão. A partir da flexibilidade do processo terapêutico unido à postura da profissional, o grupo se constituiu como um ambiente que favoreceu processos de expressão e comunicação. A valorização desses momentos propiciou alguns espaços de reflexão e de autoconhecimento, que possibilitaram o aparecimento da condição de sujeito em algumas situações.

2) As atividades no processo terapêutico como possibilidades de recursos de mudança. O principal instrumento terapêutico utilizado no grupo foram as atividades, mais especificamente os jogos e dinâmicas de grupo. A princípio elas foram planejadas para contemplar objetivos específicos relacionados ao estímulo de determinados aspectos de origem orgânica. Porém, na prática, ao longo dos processos do grupo, elas se constituíram como recursos de mudança, a partir da contribuição da construção de espaços de discussão e reflexão.

\section{3) A ênfase nos aspectos técnicos e procedimentos como recursos de mudança}

em detrimento do sujeito. Apesar de no grupo terem surgido momentos em que apareceram a condição de sujeito, percebemos que as ações da TO não foram intencionais no sentido de favorecer esse aparecimento. As ações da profissional, mesmo reconhecendo a singularidade e as questões contextuais além do diagnóstico, manifestado 
no estímulo aos espaços de expressão, não exploravam esses momentos como possibilitadores de mudança. O "sucesso" terapêutico estava relacionado com questões externas ao sujeito.

\subsection{O espaço escolar}

A subjetividade social, a partir de espaços sociais que se interligam e configuram a dimensão subjetiva de pessoas e grupos, tem relevância e implicações nos diferentes tipos de configurações nos problemas humanos (González Rey, 2012). Dessa forma, buscamos compreender como estava organizado o espaço escolar, contexto comum aos adolescentes da pesquisa, a partir de algumas relações sociais com os professores, compreendendo as implicações dessa questão no processo de configuração subjetiva dos alunos em situações de dificuldades de aprendizagem.

A construção do cenário de pesquisa nesse espaço foi realizada através de visitas, primeiramente a fim de conhecer a estrutura e algumas atividades da escola, assim como iniciar a reflexão sobre os possíveis colaboradores que poderiam fazer parte da pesquisa. Em uma segunda visita, utilizamos os instrumentos escritos com todos adolescentes que participavam do grupo, a fim de posteriormente selecionarmos três deles para realizarmos sistemas conversacionais, a partir de encontros individuais.

Durante esse período, a partir de observações e alguns relatos, escolhemos duas profissionais para participarem como colaboradoras da pesquisa, representando o contexto escolar. As professoras escolhidas foram: Carla*, responsável pela sala de recursos, e Camila*, que ministra disciplina de Artes para os $7^{\circ}$ e $8^{\circ}$ anos do ensino fundamental. Assim, buscamos compreender as relações sociais com os professores a partir de dois espaços da escola: sala de aula e a sala de recursos pedagógicos.

O espaço da sala de recursos de forma recorrente era citado pelos adolescentes durante momentos do grupo com a TO, assim como o relacionamento que tinham com a professora responsável, Carla, que também foi relatado posteriormente durante os encontros individuais. A professora Camila foi escolhida a partir dois fatores: o primeiro foi a situação peculiar que ocorreu entre ela e o George, relatada por ele durante um momento do grupo; e o segundo, ela foi citada pela coordenadora da sala de recursos 
como uma das únicas professoras que falam e elogiam os alunos George e Yara durante o conselho de classe. Assim, concluímos que ambas as profissionais poderiam representar pessoas importantes para compreendermos de maneira geral sobre os espaços da escola e as manifestações desses alunos.

\subsubsection{A sala de aula}

Camila ministra a disciplina de artes para Yara e George, em turmas distintas. Para fins deste trabalho queremos destacar o relacionamento da professora com o aluno e o posicionamento dela perante outros professores. Em um encontro do grupo, George falou que para ele gostar de determinada disciplina dependia do relacionamento com o professor. Contou que ele se considera uma pessoa difícil, mas que tem que ir sendo conquistado aos poucos. Então, citou o exemplo da professora Camila que, no início, não a suportava, mas que aos poucos ela o conquistou, e atualmente, ele diz que ama a professora e a disciplina de artes. Ao conversar com a professora, ela contou sobre os conflitos iniciais com George e o processo de mudança na relação entre eles. Ela relata que no início eles não tinham um bom relacionamento, o que tinha implicações nas ações de George durante a aula dela.

\footnotetext{
"Ele fazia de tudo pra poder me irritar, então se eu começava a falar ele começava a falar junto, a gritar junto comigo, passeava o tempo todo pela sala, saía sem minha autorização, ficava passeando pela escola inteira [...] na maior parte das vezes ele me enfrentava 'não vou copiar isso, não gosto de você, não quero [...]'. E certa vez ele me irritou tanto, falando palavras de baixo calão pra mim, e falou que não queria mais ser meu aluno. Então ele me irritou bastante, ria na minha cara, diante dos outros. E com isso, fiquei muito chateada, muito triste, saí de sala de aula chorando, falei que não ia dar mais aula para aquele menino [...] (Professora Camila, sistema conversacional)".
}

Porém, apesar do desejo de desistir de aula para a turma, ela diz ter percebido a necessidade de encontrar uma solução para esse conflito, então propôs um acordo com ele. A atitude da professora aponta que nesse momento ela se assumiu como sujeito perante essa situação, pois, apesar de um contexto que inicialmente estimulava a desistência, ela sentiu a necessidade de se reposicionar e criar um caminho alternativo 
para resolver a situação. Assim, propôs uma conversa individual com George, na qual pediu a colaboração dele no relacionamento com ela e com a disciplina, para que assim, ela também pudesse ajudá-lo de alguma forma com sua aprendizagem.

"Então assim, concordamos e entramos nesse acordo. O George passou a prestar atenção nas minhas aulas e eu passei a notar também que ele tinha certa liderança, muito positiva, em relação aos alunos. Então quando ele queria levar os alunos pra fazer bagunça, ou irritar um professor, ele conseguia, mas também quando ele queria levar os alunos a prestarem atenção na aula, a estudar, ele conseguia, que foi o que ele fez: 'Gente, vamos prestar atenção aqui na professora'." (Professora Camila, sistema conversacional).

A professora notou essa liderança de George e novamente conversou com ele, elogiando essa sua qualidade. Com isso, percebeu que ele foi mudando o comportamento na disciplina e também no relacionamento com ela, passando a participar das aulas e a se interessar pelo conteúdo, e assim, quanto mais ela o elogiava, ele melhorava o comportamento e o desenvolvimento na matéria. Em certa ocasião, ao conversar com George, ela descobriu que ele gostava de cantar, então passou a pedir que em alguns momentos da aula ele cantasse um pouco, o que o deixou muito feliz.

As atitudes de Camila reafirmam o posicionamento como sujeito, responsabilizando-se no processo de aprendizagem do aluno, que se manifesta em preocupação e atenção, além do espaço da sala de aula. A professora relatou que um dia organizou junto com George um planejamento para vida dele, delimitando objetivos a curto, médio e longo prazo de acordo com os sonhos dele. E assim, organizaram uma rotina de estudos e algumas estratégias de mudanças para que ele pudesse alcançar determinadas metas, conforme os planos que ele tinha para o futuro.

A professora, ao buscar alternativas para a resolução dos conflitos com o aluno e, posteriormente, ao estar implicada nesse processo pedagógico, favoreceu a construção de um ambiente que possibilitou que George se reposicionasse no relacionamento com ela e com a disciplina. A construção desse espaço possibilitou que o aluno produzisse novos sentidos subjetivos em relação à professora e à disciplina, gerando mudanças na configuração subjetiva da sua aprendizagem, que se manifestou na mudança de comportamento observada pela professora. Conforme González Rey (2014), na aprendizagem o aluno torna-se sujeito quando desenvolve um roteiro diferenciado sobre 
o que aprende se posicionando criticamente e de maneira reflexiva. Esse posicionamento é gerado a partir do momento em que ele produz novos sentidos subjetivos. Portanto, podemos perceber que George assumiu a posição de sujeito perante a aprendizagem dessa disciplina, pois, conforme relato dele e da professora, o aluno se mostrou implicado com o conteúdo, participando das aulas e atividades e realizando questionamentos teóricos.

Os novos sentidos subjetivos em relação à amizade e acolhimento produzidos a partir do relacionamento de George com a professora permitiram uma reconfiguração subjetiva da aprendizagem, que se manifesta em suas atitudes de respeito perante a professora, a partir de seu comportamento em sala de aula. Camila enfatiza que "hoje, eu posso chamar atenção dele, de um comportamento que não foi adequado em sala de aula, eu chamo 'George, o que você fez não foi legal'. E hoje ele já aceita eu chamar atenção dele, porque eu já chamo de uma maneira mais amiga [...].” Esse posicionamento da professora se articula com o discurso de George, que durante uma ocasião no grupo, comentou que o professor ao chamar a atenção dele poderia demonstrar verdadeira preocupação e cuidado, como um amigo, e não simplesmente o recriminando por suas atitudes.

Essa experiência também representou mudanças na constituição subjetiva da professora, implicando um reposicionamento perante sua prática pedagógica, que se manifesta, por exemplo, em suas atitudes nas reuniões coletivas da escola e com outros professores. Carla citou que a professora Camila é quem mais elogia a mudança desses alunos considerados "difíceis" perante todo o grupo de professores. Ao conversar com a professora, Camila relata que ainda existem muitos profissionais que não percebem as qualidades e os avanços positivos dos estudantes na aprendizagem, pois estão centrados nos problemas, principalmente de comportamento, o que tem implicações no relacionamento professor-aluno. Ela disse, por exemplo, que muitos professores atuais de George acham que ele é "complicado e difícil". Porém, ela conversa com eles a fím de que possam compreender os avanços que o aluno teve, a partir de processos de mudança que eles manifestam em seus comportamentos em sala de aula. Então, conta que, aos poucos, os professores estão começando a olhar para as qualidades dos alunos, embora esse processo de conscientização e de mudança do “olhar do professor” às vezes seja um pouco complicado e lento, o que para ela pode ter relação com a formação profissional. 
"[...] Porque os professores tratam no geral, acham que eles não deviam ter esse comportamento, e não percebem a qualidade deles [...]. Às vezes na graduação não fomos preparados pra trabalhar com o diferente, fomos preparados pra trabalhar com todos iguais, todos quietinhos, todos assim, muito comportadinhos, e o aluno não é assim [...] (Professora Camila, sistema conversacional)."

A atuação desses professores, descrita por Camila, nos remete a práticas relacionais que tem como base a valorização dos rótulos provenientes do diagnóstico, relacionada "à falta de algo" em detrimento das qualidades do sujeito. Vygotsky (1997) alerta que, muitas vezes, as teorias psicológicas baseadas na compreensão do desenvolvimento a partir de aspectos puramente quantitativos, ganham influências nas práticas educativas. E assim, elas são baseadas em princípios e definições de faltas e limites, não compreendendo o desenvolvimento como um processo qualitativamente diferenciado. Dessa forma, podemos relacionar as atitudes desses professores com uma formação profissional que tem como base princípios que valorizam os aspectos homogêneos e quantitativos do desenvolvimento, em detrimento da compreensão qualitativa, na qual os aspectos sociais e subjetivos se tornam relevantes.

Atualmente, Camila conta que a partir dessa experiência ela sempre procura elogiar os alunos reconhecendo suas qualidades e dizendo diretamente para eles, assim como busca conscientizar outros professores sobre o valor do relacionamento com os alunos. Portanto, podemos destacar a relevância do papel do "outro" nos processos de aprendizagem. A professora, ao se aproximar do aluno, consegue perceber as qualidades por trás dos rótulos do comportamento "difícil”" e, assim, favorece a construção de um ambiente de valorização, criando estratégias que possibilitaram a emergência de George como sujeito de sua aprendizagem nessa disciplina.

Conforme destaca Tacca e González Rey (2008), é importante que os professores entendam a aprendizagem como processo subjetivo e, desse modo, possam buscar compreender a singularidade frente aos processos de conhecimento, o que possivelmente reduziria os rótulos estereotipados. Essa situação nos faz refletir sobre o papel do professor na aprendizagem do aluno, que está além de suas funções metodológicas de ensinar-aprender, mas que tem a base essencial no relacionamento entre pessoas. 


\subsubsection{A sala de recursos pedagógicos}

Carla é a professora responsável pela sala de recursos pedagógicos da escola e também conta com o auxílio de alguns monitores nesse trabalho. Ela relatou brevemente sobre o trabalho nesse espaço, que consiste na realização de atividades lúdicas e pedagógicas com os alunos considerados "especiais", em turno contrário ao horário de aula. A média de horas de atendimentos é $2 \mathrm{~h}$ por dia, e entre $4 / 6 \mathrm{~h}$ por semana. Segundo Carla, o tempo de atendimento é dividido em duas partes: no primeiro momento, ela auxilia os alunos na realização das atividades pedagógicas passadas pelos professores na turma regular; e em outro momento, disponibiliza um tempo para eles realizarem atividades lúdicas, como: jogos, utilizar os computadores, jogar vídeo game, entre outros. Também relatou que elabora uma rotina de estudos para cada aluno e, para isso, conta com o apoio da família, que é bastante participativa, segundo ela.

De acordo com a Secretaria de Educação, na sala de recursos não poderia ter atendimento aos alunos com diagnóstico de TDAH, porém, apesar disso, Carla os atende nesse espaço, o que está implicado com motivações pessoais da profissional. A princípio, ela relacionou essa atitude com a preocupação em relação a eles, com objetivo de proporcionar um atendimento além da sala de aula.

Ao analisarmos a opção de Carla, percebemos que essa preocupação relaciona-se com questões mais complexas, a partir de elementos de sua história de vida, que se manifestam na constituição do trabalho pedagógico da professora. Carla relata que há algum tempo foi diagnosticada com TDAH, sendo também mãe de um adolescente, atualmente com 19 anos, diagnosticado com o transtorno. O filho constitui um núcleo de sentido subjetivo importante para Carla, participando da configuração subjetiva de sua atuação profissional com os alunos com esse diagnóstico, conforme relatado por ela: “[...] por causa dele (filho) comecei a trabalhar com TDAH. A minha motivação foi ele”. Além disso, relatou que, conforme documento, só poderiam ser atendidos, na sala de recursos, alunos com o laudo para o atendimento, mas como às vezes demora muito, ela realiza alguma intervenção quando percebe que um adolescente está precisando. Os motivos dessa ação se relacionam com a experiência própria e com a demora em sair o diagnóstico do filho. “[...] É porque meu filho sofreu isso, entre um neurologista e outro, o laudo não 
saía, ele veio ter laudo no Ensino Médio, no $2^{\circ}$ ano... uma mãe pode esperar? Não pode." (Carla, sistema conversacional).

Assim, compreendemos os motivos como configurações subjetivas que se organizam no curso da ação (González Rey, 2012). Dessa forma, elementos da história de vida de Carla se articulam na configuração subjetiva em relação ao transtorno, que se desdobram na produção de sentidos subjetivos relacionados à compreensão e alteridade em relação a esses adolescentes e se manifestam em sua prática pedagógica.

"[...] Eu sou TDAH. E eu me lembro como era... na escola. Então eu sempre me coloco no lugar deles. Aí eu falo pra ele" Ah eu me lembro "[...] Então assim, eu me coloco como um deles, aí há uma identificação. [...] Lembro como eu me sentia, como eu tinha vergonha de levantar a mão pra perguntar... Porque eu via todo mundo fazendo e eu fingia que tava fazendo, via todo mundo fazendo... 'Vou fingir também' Aí rabiscava ali, porque eu não tava entendendo nada, mas eu tinha vergonha... Então, eu imagino que com eles é da mesma forma [...]. Então assim, como venho da família com TDAHs, eu compreendo a dificuldade de ser TDAH (Carla, sistema conversacional)".

A experiência da professora nos permite destacar as implicações da subjetividade social do espaço da sala de aula. Esse ambiente às vezes não se torna um local favorável à aprendizagem, por estar relacionado com a produção de sentidos subjetivos que impedem a expressão e posicionamento do sujeito perante suas dificuldades de aprendizagem, que se manifestam, por exemplo, através do sentimento de vergonha. Assim, Carla parece compreender a aprendizagem como um processo dinâmico e singular, com implicações dos espaços sociais e do relacionamento professor-aluno.

[...] “(o professor) só fala 'Ah você não tá aprendendo porque não tá estudando em casa. Você não tá fazendo a tarefa... não tá fazendo o trabalho...' $E$ aí ele não leva em consideração a vida particular, pessoal daquele menino... o que ele passa em casa, que ele não tem uma sala pra estudar, uma mesa... Ele tem um irmão que assiste à televisão e não tem onde estudar... Então é todo um contexto, que na sala de aula o professor não leva em consideração, e na sala de recursos a gente vê o aluno não como um número, mas cada um é diferente... entendeu? [...]" (Carla, sistema conversacional). 
Ela acredita que um dos grandes desafios nas práticas pedagógicas está no relacionamento do professor com os alunos, pois percebe que muitos profissionais não buscam se aproximar dos estudantes para compreendê-los em suas especificidades. Porém, percebe-se que a partir de suas experiências, Carla constitui sua prática pedagógica com ações e atitudes de acolhimento e compreensão que permitem ao aluno se expressar no processo de aprendizagem. A professora adota a postura de aproximação com os alunos, a partir da construção de vínculos de amizade. "A gente cria um vínculo de amizade mesmo. Eles não são meus alunos, são meus amigos. Entendeu? A diferença é essa... Não existe aquele muro, eu sou professora e você é aluno [...]" (Carla, sistema conversacional). O relacionamento dela com os estudantes favorece a criação de espaços que permitem compreender a singularidade de cada um no processo de aprendizagem, sem atitudes punitivas ou preconceituosas.

"Eu não costumo chegar dando bronca no aluno, eu chego trazendo o aluno pra entender como aquilo funciona [...]. Na sala de aula, ele tem vergonha de dizer 'Eu não sei', e lá pra mim, eles não têm vergonha de dizer 'Eu não sei'. A gente também não tem aquele "pré-conceito" formado, ah o menino não sabe isso, então ele é burro... Lá não tem isso (sala de recursos), não se sabe por que em algum momento da vida escolar dele ele deixou de aprender [...]" (Carla, sistema conversacional).

Tacca (2004) aborda a importância de o professor organizar um ambiente que favoreça a vivência de momentos de intimidade, possibilitando oportunidades para processos de desenvolvimento. Portanto, as produções subjetivas de Carla perante o processo de aprendizagem geram implicações para que ela se assuma como sujeito em suas ações pedagógicas, colocando-se no lugar do "outro" e se responsabilizando com o processo de aprendizagem. Com isso, o relacionamento dela com os alunos cria um ambiente que favorece processos de posicionamento dos sujeitos, gerando possibilidades de desenvolvimento. O planejamento das atividades pedagógicas além do espaço de trabalho constitui-se como outro elemento que nos permite destacar o comprometimento e responsabilização de Carla nesse processo, configurando-se como um sujeito ativo.

“[...] Eu gosto do que eu faço, eu tô em casa e vejo uma coisa na TV: 'Nossa, vou levar isso pros meninos'. Tô no computador: 'Caramba é uma coisa nova, vou levar'. Então assim, minha cabeça funciona o tempo inteiro em prol do que eu vou fazer de bacana, de novo. E aí 
eu divido com eles, eu planejo com eles [...]" (Carla, sistema conversacional).

Dessa maneira, a flexibilidade na prática pedagógica da profissional, a partir de ações criativas e da busca ativa por alternativas para complementar seu planejamento, possibilita a construção de um espaço que valoriza os adolescentes no processo de aprendizagem. E assim, ao se constituir como sujeito desse processo, as suas ações e atitudes contribuem para favorecer momentos em que os adolescentes também se constituam como sujeitos em determinadas ações. Carla relatou, por exemplo, que eles realizam as provas na sala de recursos com ela. Certa vez, precisou se ausentar enquanto eles estavam fazendo uma prova, porém havia pedido que eles ficassem sentados e sem conversar, mas quando ela retornou para a sala eles estavam em pé e conversando. Ela disse que chamou a atenção deles de maneira não punitiva, mas dizendo que estava triste, pois eles tinham traído a confiança dela. Carla também percebeu que eles ficaram chateados com essa situação. No dia seguinte, ela foi aplicar outra prova para eles e novamente precisou deixá-los sozinho em sala, porém quando retornou estavam todos em silêncio. E quando perguntou o motivo, Carla disse que eles falaram " [...] porque ontem a gente decepcionou você, então hoje nós combinamos que ninguém não vai nem olhar pro lado." Essa situação ilustra o aparecimento do sujeito nessa atitude, a partir da construção de um ambiente baseado nas relações sociais. Assim, podemos destacar que um ponto central das ações pedagógicas de Carla está no relacionamento com os alunos, favorecendo a criação de espaços que possibilitem processos de desenvolvimento subjetivo.

Com base na breve análise das relações sociais nesses dois espaços da escola, propomos alguns pontos de destaque:

1) As implicações das relações sociais no desenvolvimento subjetivo. No caso das duas professoras, destacamos a aproximação e a construção de vínculos de amizades com os alunos que possibilitaram espaços favorecedores de produções subjetivas. Destacamos a produção de novos sentidos subjetivos a partir do relacionamento entre a professora Camila e George, possibilitando uma reconfiguração subjetiva do aluno em relação à aprendizagem da disciplina. 
2) Elementos subjetivos na prática pedagógica das professoras. Conforme observado, enfatizamos nesse processo também a constituição subjetiva do professor, a partir de experiências e elementos de sua história de vida, com implicações na prática pedagógica de ambas. A professora Camila se reposicionou em sua ação pedagógica, a partir da reconfiguração subjetiva, com base na experiência vivenciada com George. No caso da professora Carla, destacamos as implicações de elementos de sua história de vida e experiências na configuração subjetiva de sua prática.

3) A subjetividade social no espaço escolar . No discurso das duas professoras, podemos destacar elementos da subjetividade social, que incluem atitudes dos profissionais da escola, com implicações no processo de aprendizagem. Ambas deram ênfase à importância do relacionamento professor-aluno no processo de aprendizagem. Porém, devido aos rótulos e ações preconceituosas que permeavam o espaço escolar, muitas vezes esse relacionamento não se constituía como um elemento subjetivo capaz de contribuir para o desenvolvimento dos alunos diante das dificuldades de aprendizagem.

\subsection{Caso Yara}

\subsubsection{Caracterização e construção do cenário de pesquisa}

Yara, adolescente de 15 anos, nasceu no Rio de Janeiro, mudou-se para Brasília ainda pequena, com a mãe e um irmão menor. No início dos encontros, ela estava morando na mesma casa com o namorado, a mãe, os dois irmãos mais novos, um menino e uma menina, de pais diferentes, e com o atual companheiro da mãe, pai da irmã caçula. Não conheceu o pai biológico, pois a mãe terminou o relacionamento quando descobriu que ele estava envolvido com drogas.

Além disso, contou que, quando a mãe estava grávida dela, o pai pediu que a abortasse. Após o término do relacionamento, a mãe foi morar no Ceará, onde se envolveu com outro rapaz, o pai do irmão dela. Porém, com o fim desse relacionamento, a pedido de um tio, vieram para Brasília, a mãe, ela e o irmão. Um tempo depois, a mãe conheceu 
o pai da caçula, e após nove anos de relacionamento nasceu a irmã. Ao longo da pesquisa, a mãe ficou grávida. Yara disse que não sabe quem é o pai, pois a mãe havia terminado o relacionamento com o ex-companheiro, pai da irmã caçula, e por isso, terão que arrumar outro lugar pra morar, não sabendo se terão condições de morar todos em uma mesma casa.

A rotina de Yara consiste em durante a semana acordar aproximadamente $6 \mathrm{~h}$ da manhã para arrumar o cabelo e maquiar-se antes de ir para a escola. Depois vai à aula e, quando chega à casa, a primeira coisa que faz é almoçar, citando que às vezes almoça duas vezes, uma em casa e outra na casa dos pais do namorado. À tarde, diz que assiste novelas, que é um dos seus passatempos prediletos. Por volta das $19 \mathrm{~h}$, segundo ela, realiza algumas tarefas de casa inclusive cuidar dos cachorros, e depois assiste a outras novelas. Dorme por volta das $22 \mathrm{~h}$. No final de semana, diz que fica mais em casa, ou na dela ou do namorado, citando que gosta de ficar na casa do namorado porque tem internet, então eles assistem a séries. As principais atividades de lazer segundo ela é ver novela, cuidar do cachorro e comer. Porém, ela diz que queria se exercitar mais, porque tem medo de ter problemas de saúde. Apesar disso, Yara está com um peso adequado para sua faixa etária. Também relatou que gosta de dançar, mas que, por não saber muito bem, tem vergonha. Yara cursa $08^{\circ}$ ano do ensino fundamental na escola pública regular de ensino, onde foi realizada a pesquisa.

Os primeiros contatos com a adolescente ocorreram no período de observação do grupo com a TO, quando notei que a adolescente adotava certos comportamentos e expressões que chamaram minha atenção. Yara participou de todas as reuniões. Em todos os encontros mostrava-se visivelmente impaciente e agitada, o que se manifestava em ações e expressões corporais. A sua fala era muito acelerada, o que muitas vezes dificultava que fosse compreendida por todos. Além disso, repetia por várias vezes expressões como: "não sei”, "não quero fazer", "tô nervosa e estressada", "quero ir embora", "tô com fome".

Às vezes não queria participar das atividades, apesar do incentivo da terapeuta. Quando participava de um jogo e perdia, era notável a sua frustração, o que a deixava mais impaciente e nervosa, porém quando ganhava demonstrava notável alegria. Em um dia, comentei sobre a pesquisa para todos os participantes e ela concordou em participar. Durante o grupo, Yara não se aproximava muito de mim, porém no primeiro dia em que 
cheguei à escola para aplicar os instrumentos com ela e com os demais, aproximadamente um mês depois da minha última visita ao grupo, ela me recebeu de forma bem receptiva e entusiasmada. Notei que o comportamento de Yara que se manifestava em sua fala e em suas expressões corporais estava visivelmente diferente daquele do grupo. Ela estava mais calma, com a expressão facial menos tensa e falava mais devagar. Além dos instrumentos escritos respondidos por ela, esse comportamento intrigante de Yara foi um dos principais motivos para a escolha da adolescente como participante da pesquisa. Assim, quando retornei para a primeira conversa individual com ela, essa perceptível mudança de comportamento estava ainda mais evidente. A cada encontro, Yara me recebia de maneira mais afetuosa e carinhosa e dizia que estava com saudades. Em uma ocasião informal, por coincidência, encontrei-me com ela em um local público. Ela espontaneamente me abraçou com uma expressão de surpresa. Assim, começamos a construir nossas primeiras hipóteses a fim de compreender mais sobre Yara e suas configurações subjetivas.

\subsubsection{A subjetivação do rótulo de TDAH e a dinâmica subjetiva}

Segundo Yara, ela tem o diagnóstico de TDAH. Atualmente não toma medicação, mas disse que durante um período tomou Ritalina e outro remédio para estimular a concentração. Porém, não gostava porque "ficava lerda e sem fome" e muito sonolenta, o que a atrapalhava a estudar. Há algum tempo, o médico retirou os remédios, e disse que era para a mãe ficar observando o comportamento dela, caso percebesse a necessidade, ele retornaria com a medicação.

No grupo, constantemente dizia que estava com raiva, nervosa, estressada e com fome, o que se manifestava em seu comportamento, a partir de ações e atitudes inquietas e agressões verbais em relação a outros colegas. Aparentemente, esses comportamentos eram incompreensíveis. Apesar de a profissional perguntar diretamente, ela não relatava o que o motivo deles.

Yara: Hoje tô com raiva.

TO: Por quê?

Yara fica calada. Início da outra rodada. Yara começa a desrespeitar os outros, com palavrões. 
TO: Yara, depois vamos conversar.

Yara: Eu não queria vir hoje, estava me escondendo.

Est.: Você não gosta da gente?

Yara: Gosto, mas tava estressada.

No caso de Yara, tornou-se importante investigar a forma como estava configurada subjetivamente a aprendizagem nela, por trás dos seus comportamentos, que se manifestavam em sua fala e expressões corporais, sendo considerados típicos do TDAH. A dinâmica subjetiva da adolescente nos apontou para a família como um forte núcleo na produção de sentidos subjetivos de base simbólico emocional, que se manifestaram em outros contextos, como no espaço escolar, hipótese que será analisada a partir de alguns elementos.

Apesar de no complemento de frases ter escrito "minha família... linda", quando a questionei o que mudaria na vida dela, se pudesse mudar algo, conforme a frase do complemento de frases, que ela não preencheu, disse que queria mudar a família.

"Minha família, assim, eu queria só eu, minha mãe, meu irmão, minha irmã, meu outro irmão Israel* e só [...] são tudo de pai diferente. Eu não queria mais homem nenhum, porque todo homem que minha mãe arruma, magoa ela. É... Aí eu preferia que ficasse só ela mesmo, ela podia morrer sozinha, mas ela tinha eu pelo menos, só... Melhor que outro homem na vida dela, enchendo o saco dela (Yara, sistema conversacional)".

A partir dessa colocação, há alguns elementos que permitem elaborar hipóteses de como a família está organizada subjetivamente para Yara. Os relacionamentos da mãe aparecem como um elemento importante na lógica configuracional da família da adolescente, que perspassam por sentimentos relacionados ao desejo de proteção, preocupação e ciúmes em relação à figura materna. É possível notar um desejo de querer protegê-la de algum sofrimento a partir de seus relacionamentos amorosos, tendo os sentimentos da mãe implicações na produção subjetiva de Yara. No complemento de frases, ela escreveu: "Fico feliz... mãe", relacionando a felicidade dela com os sentimentos da mãe. E durante outro momento relatou " [...] eu fico triste por ver minha mãe, como ela fica triste, que ela não tem nem força pra ir pro trabalho [...]”.

É interessante notar que no trecho anterior Yara relaciona em uma mesma frase os sentimentos dela com os da mãe e com a questão de ter um trabalho. Em outros relatos 
e situações, também foi possível observar a relação entre esses elementos. Nos momentos dos encontros individuais, realizados em um período após as observações no grupo, era visível a mudança no comportamento de Yara, conforme relatado. Ao ser instigada sobre o motivo, ela relacionou com a felicidade da mãe e com o emprego.

Pesq.: E nesses últimos dias você está calma, tem algum motivo?

Yara: Não... É porque minha mãe tá feliz, tá muito feliz entendeu? Com emprego [...]

Podemos estabelecer um indicador da relação entre os sentidos subjetivos produzidos em relação à figura materna e a situação financeira da família, como elementos importantes na base da produção de outros sentidos subjetivos que se manifestam no comportamento de Yara em outros contextos. Um elemento que indica a dificuldade financeira da família é a forma com que aparece com frequência em seus discursos o assunto sobre comida. Em todos os encontros, ela dizia que estava com fome e que queria comer, às vezes, quando contava alguma história também aparecia esse assunto. No instrumento "3 coisas", escreveu "comer" dentre as três coisas que mais gosta de fazer.

Em um momento no sistema conversacional, também relatou, por mais de uma vez, que dentre as coisas que ela mais gostava de fazer era comer. "[...] Se tivesse uma lasanha era melhor, mas como não tem a gente come biscoito mesmo" (Yara, sistema conversacional, relato sobre o que ela comia no almoço em sua casa). Provavelmente, a mãe, na maior parte do tempo, foi a principal provedora financeira da família devido à ausência do pai e à instabilidade nos relacionamentos afetivos. Nos últimos encontros, Yara tinha dito que devido ao término do penúltimo relacionamento da mãe, eles teriam que mudar de casa e acreditava que a mãe não teria condições de manter todos eles em um mesmo local, provavelmente, eles teriam que se separar. No mesmo dia, contou que ficou triste com o término do último relacionamento da mãe, pois o homem era legal, tinha dinheiro e um carro. Portanto, a instabilidade nos relacionamentos afetivos da mãe também estava relacionada com a instabilidade financeira muitas vezes vivenciada pela família, o que gerava implicações nas produções subjetivas de Yara, que se manifestavam em seu comportamento em diversas situações. 
Em determinada sessão do grupo, quando os adolescentes estavam dividindo o que cada um iria levar para o lanche coletivo no próximo encontro, Yara comentou: "Vocês (indicando a terapeuta, as estagiárias e a pesquisadora) tragam salgados, porque vocês trabalham e minha mãe não" (relato de Yara no grupo terapêutico). Além disso, comentou que, se Olívia não trouxesse nada para partilhar no lanche, ela não iria participar, pois como a mãe dela trabalhava tinha dinheiro para comprar o lanche. A adolescente parecia relacionar ter emprego como uma condição para poder levar o lanche para partilhar no grupo. Após os diálogos com Yara, compreendemos que esse discurso dito por ela naquele momento estava relacionado com o período em que a mãe estava desempregada. O desemprego parecia evocar diversos sentidos subjetivos em Yara naquele momento e muitas vezes se manifestavam em seus comportamentos agressivos com os colegas. Após um período, disse que passou a incentivar a mãe a realizar mudanças de atitudes a fim de conseguir um emprego.

\begin{abstract}
“"Mãe, você para de beber cachaça, porque se não você não vai encontrar um trabalho nunca' Porque assim, quando ela bebe muito, no outro dia ela acorda morta. Aí ela bebia demais né? Eu disse, "mãe você para de beber pra senhora arrumar trabalho, porque quando a senhora bebe demais no outro dia não consegue levantar, aí a senhora vai ficar faltando e vai acabar perdendo o emprego de novo" (Yara, sistema conversacional).
\end{abstract}

Yara relata que após esse estímulo a mãe conseguiu o atual emprego, mas disse que tem medo que ela seja demitida, pois pouco tempo depois a mãe ficou grávida, o que não deixou Yara feliz. Esse relato reafirma a relação entre a instabilidade financeira e os relacionamentos da mãe. No complemento de frases, ela completou " $E$ difícil... trabalhar". No diálogo, ela relatou que essa dificuldade em trabalhar estava relacionada com a dificuldade em arrumar emprego.

"É porque assim, emprego nesse país tá difícil né? Meu namorado entregou tanto currículo, tanto, eu ajudei ele a entregar. [...] "[...] É muito difícil arrumar emprego. Minha mãe, ainda bem que ela arrumou... Porque assim, é muito ruim ficar dependendo de homem né? Ela arrumou emprego agora" (Yara, sistema conversacional). 
O trecho "[...] é muito ruim ficar dependendo de homem", unido aos outros elementos, permite-nos construir um indicador sobre a situação financeira da família e os relacionamentos afetivos da mãe como fontes importantes de sentidos subjetivos que participam da configuração subjetiva de Yara, com desdobramentos no processo de aprendizagem.

Durante um diálogo, ela relacionou as emoções expressas em seu comportamento com base em experiências vividas no contexto familiar, o que gerava desdobramentos na produção de sentidos subjetivos que participavam da sua configuração subjetiva na aprendizagem. Assim, os sentidos subjetivos de Yara no contexto escolar não se desvinculam dos sentidos subjetivos em diferentes áreas de sua vida.

Pesq.: Sobre o grupo, não sei se você lembra, mas você por muitas vezes falava que tava nervosa, estressada chateada... Você lembra se tinha motivos específicos ou não?

Yara: "E... era por causa da minha mãe. É porque assim, [...], ela me chamava de burra né? Aí meu irmão... Ela chamava de burra assim 'Ah Yara, você tem que estudar, parece uma burra'. Aí tá, eu deixava quieto. Só que aí meu irmão me chamava direto de burra, meu irmão, entendeu? Aí eu ficava assim chateada... Só que aí minha mãe brigou com ele e ele parou de me chamar de burra" (Yara, sistema conversacional).

A palavra "burra" parece evocar sentidos subjetivos em relação à inferioridade e incapacidade que se manifestam na configuração subjetiva de sua aprendizagem, que também podemos observar no instrumento complemento de frases: "Quando não consigo aprender me sinto... burra". No grupo, Yara dizia por diversas vezes antes de alguma atividade que não sabia fazer algo, ou que não queria fazer, demonstrando impaciência. "Não sei escrever nada/ Não vou ler/ Não quero fazer nada", essas eram expressões que Yara falava durante encontros do grupo de maneira muito rápida e às vezes incompreensível.

Os elementos de negação também foram observados nos instrumentos escritos, como no instrumento complemento de frases e nas "3 coisas". Ela deixou em branco ou respondeu a palavra "nada” em várias questões, e não realizou o instrumento de desenho livre "O mundo ideal”. Essas questões estavam relacionadas com processos de mudanças, sonhos, desejos ou problemas. Ela não preencheu: meu maior sonho.../ se pudesse mudar 
algo, mudaria.../ a escola perfeita seria... . E colocou a palavra "nada" nas seguintes questões: Eu queria... nada, Odeio... nada, Meu maior problema... nada. No instrumento das 3 coisas, “ 3 coisas que mudaria na escola: nada”. Podemos ter um indicador de que os sentidos subjetivos em relação à incapacidade e inferioridade participam da aprendizagem de Yara, manifestando-se através da negação do sujeito, no qual ela não se responsabilizava pelo seu processo de aprendizagem.

Segundo González Rey (2011a), as operações intelectuais em crianças com dificuldades de aprendizagem podem ficar bloqueadas por emoções que as impedem de se tornarem sujeitos nessas operações. Os sentidos subjetivos em relação à incapacidade e inferioridade pareciam se manifestar em emoções, como nervosismo e impaciência. "A emoção é uma forma de expressão da pessoa diante de uma experiência vivida" (González Rey, 2007, p.139). Dessa maneira, podemos ter um indicador de que as emoções participavam das bases dos processos simbólico-emocionais de Yara com implicações na configuração subjetiva da aprendizagem, que se expressava em comportamentos concretos. No grupo, durante a "Atividade da História", devido a sua letra, que era de difícil compreensão, sofreu alguns comentários e brincadeiras dos colegas, o que a deixou mais nervosa e impaciente.

Iago: "Que letra feia" (após receber um papel) Yara. "Já cansei dessa história. Pronto." Iago: "Tô com dificuldade de entender a letra." Yara: "Pula meu querido. Quero ir embora" (fala rápida).

Além disso, a negação do sujeito também podia estar relacionada com um indicador da existência de sentidos subjetivos em relação ao erro e à vergonha, que antecipava as situações de fracasso e a impedia de se posicionar. Nessa mesma atividade em que Yara havia ficado impaciente e nervosa com o comentário sobre sua letra, a TO solicitou que todos lessem o que haviam escrito, o que a deixou visivelmente mais nervosa e ansiosa, dizendo que não iria ler. Thaís comentou que ela poderia ler por último, mas teria que ler, porém Yara falou "Não, eu começo" e iniciou a leitura lendo rapidamente. Ao terminar, justificou que não havia lido alguns trechos porque não tinha compreendido tudo. Durante o sistema conversacional, Yara relatou sobre a dificuldade de ler em voz 
alta na sala de aula, devido a alguns comentários e piadas dos colegas e que o grupo tinha ajudado nesse aspecto.

Pesq.: Você acha que o grupo te ajudou? Yara: Ajudou, ajudou muito. As conversas... A leitura melhorou muito assim na sala. Porque tem gente que a gente lê gaguejando e fala uma palavra errada, aí tem gente que começa a rir, aí eu fico triste e não gosto de ler. Eu falo 'Não professora, não vou ler não, pode continuar... '. 'Yara, você tem quer ler... ' 'Não professora, não quero ler não'. Eu só acompanho a leitura [...]. Ajudou muito, minha leitura tá melhor agora.

Yara relatou que atualmente estava lendo em voz alta nos momentos em sala de aula, inclusive algumas vezes se prontificando para ler antes de a professora solicitar. No grupo, não foi realizada nenhuma técnica ou procedimento que estimulasse diretamente a leitura, porém esse foi o ponto destacado por Yara como uma contribuição desse espaço. É interessante que ela apresenta na mesma frase dois fatores: as conversas e a leitura como aspectos em que o grupo a auxiliou, o que nos remete ao indicador de que uma das principais contribuições do grupo foi a construção de espaços de expressão e participação dos adolescentes, nos quais eles puderam se posicionar. Podemos observar que nessa ação de ler, Yara adotou a postura de sujeito, pois, apesar de suas dificuldades adotou, uma mudança ativa em relação a essa atividade.

Em outras situações, como por exemplo, na disciplina de matemática, pôde-se perceber algumas mudanças em relação ao seu processo de aprendizagem. Em um diálogo, relatou que, quando não aprendia, ficava nervosa e com vontade de chorar, o que ocorria com frequência na disciplina de matemática, principalmente quando a data da prova se aproximava. "Eu fico muito nervosa. Eu começo a chorar do nada. No dia lá eu ia chorar, aí falei 'Não vou chorar, não vou, eu vou aguentar'. Aí eu suspirava..." (Yara, sistema conversacional).

Percebe-se que a fala da adolescente indica a tentativa de controlar as emoções que apareciam em decorrência da experiência de aprendizagem. Além disso, disse que passou a estudar mais o conteúdo de matemática com uma amiga, o que a ajudou muito, inclusive recebendo um incentivo da professora para que ela também fosse aluna destaque da turma nessa disciplina como a amiga. "Aí a Karen* foi destaque na sala dela. E a 
professora quer ver se esse mês, esse bimestre, eu seja [...]" (Yara, sistema conversacional). Os discursos anteriores citados por Yara coincidem com os momentos, observado pelas professoras e pela adolescente, os quais serão relatados a seguir, nos quais ela mudou sua postura em relação à aprendizagem, passando a se implicar nesse processo em várias disciplinas. A união desses elementos permite-nos construir um indicador relacionado ao desejo de Yara em ser sujeito, em saber se controlar e mostrar que é capaz, principalmente em relação aos processos de aprender.

Em determinado encontro do grupo, a adolescente contou que ficava nervosa porque a professora de ciências não explicava muito bem e por isso ela não conseguia compreender a matéria. Esse relato foi mais um elemento que contribuiu para a construção do indicador relacionado às implicações das emoções nos processos de aprendizagem. Durante o nosso diálogo, alguns meses após esse acontecimento, ela citou novamente sobre conflitos relacionais que tinha com a professora, porém contou sobre uma mudança de comportamento que teve na aula dela.

"Eu não to respondendo ela mais, eu não durmo mais, e ela falava tanto que eu dormia, e agora eu nem tô dormindo mais na aula dela, tô fazendo os deveres todinhos dela. Antigamente, qualquer coisa que ela vinha falar comigo eu respondia ela, qualquer coisinha, aí, ela falava 'saí da minha sala'. Aí eu falava 'Bom que eu não vejo essa cara de enjoo da senhora'(Yara, sistema conversacional).

A atitude agressiva em relação à professora pode se constituir como mais um elemento que indica a presença das emoções no processo de aprender, que se manifestam em seu comportamento. Além disso, podemos construir um indicador de que o ambiente pedagógico, a partir do relacionamento com os professores, representavam implicações no modo como Yara se posicionava diferentemente nos espaços de aprendizagem de certas disciplinas. É possível observar, por exemplo, os comportamentos diferentes que ela tinha em relação à disciplina de Ciências e História. Em um encontro do grupo, ela disse “Eu sou uma santa em história (disciplina)". Durante o dialogo, relatou que o professor era legal com ela, perguntando individualmente se ela tinha dúvidas sobre o conteúdo, e por isso gostava da matéria e se comportava na aula dele, o que, segundo ela, não acontecia em outras disciplinas. No instrumento "3 coisas", "três coisas que mais gosta de fazer: História" (referiu-se a disciplina curricular). 
Podemos inferir que na disciplina de História, a partir do relacionamento com o professor, Yara adotava a postura diferente em relação ao modo de aprender o conteúdo. Assim, podemos refletir que a constituição de diferentes espaços pedagógicos produziam sentidos subjetivos diversos que estão implicados na configuração subjetiva da aprendizagem de Yara e que se manifestam em seus comportamentos.

Apesar das implicações dos espaços pedagógicos, a complexidade da dinâmica subjetiva de Yara permite compreender outros elementos na configuração subjetiva da aprendizagem da adolescente que favoreceram processos de mudança em seus posicionamentos perante esse contexto. Yara relata ter adotado uma postura diferente na disciplina de ciências, apesar de o relacionamento com a professora continuar o mesmo. A adolescente não relatou diretamente sobre os motivos de ter adotado essa nova postura tanto nessa disciplina como em outras, conforme relatado por ela e observado pelas professoras Carla e Camila. Em algumas disciplinas como artes, educação física, português, inglês, relata que antes não participava das aulas, além de dormir e conversar muito com os colegas, porém também mudou esse comportamento. Atualmente conta que busca sempre fazer as atividades, inclusive antecipadamente, apesar de às vezes não gostar do conteúdo.

Essa mudança também foi percebida pelos professores. Durante um Conselho de Classe, Carla relatou que todos os professores reconheceram e elogiaram a mudança recente de comportamento de Yara e o avanço pedagógico em relação às notas. Assim, ela adota a nova postura que nos permite a construção de um indicador da produção de recursos subjetivos próprios, que lhe permitiram mudança de comportamento para superar as dificuldades em algumas matérias e se assumir como sujeito perante seu processo de aprender.

Apesar de não nos aprofundarmos nos recursos subjetivos desenvolvidos por Yara nesse reposicionamento perante ao processo de aprender, podemos perceber que eles estão implicados na dinâmica subjetiva singular da adolescente. Por exemplo, durante o último diálogo, relatou que estava se interessando mais pela disciplina de Ciências, porque queria ser veterinária. Então, precisava aprender o conteúdo. Na maior parte dos nossos encontros, ela relatava algo sobre animais, principalmente sobre os cachorros e que gostava de cuidar deles, inclusive os abandonados. Em um encontro, contou-me sobre o sonho de ser veterinária e em outro momento, trouxe-me dados de uma pesquisa que 
ela tinha feito em relação aos abrigos de animais em vários países. Esses elementos nos permitem construir um possível indicador da mudança de interesse e comportamento na disciplina de Ciências relacionado ao desejo de ser veterinária.

É interessante também destacar a mudança na configuração subjetiva dos sintomas do TDAH para Yara ao longo desse processo. No primeiro encontro do grupo, quando a TO perguntou por que eles achavam que estavam naquele espaço, ela disse que era inquieta e falava muito rápido. Porém, alguns meses depois, durante o diálogo, essas questões não apareceram mais em seu discurso. Durante alguns momentos, a adolescente relatou que acreditava não possuir o transtorno e o que a incomodava era a distração em alguns momentos. Em outro momento, quando a questionei sobre a fala acelerada, que era uma das principais características evidentes em seu comportamento, ela não relacionou essa questão com o transtorno, mas com suas emocionalidades.

Pesq.: Yara, sabe uma coisa que eu estava percebendo?A questão da sua fala. Às vezes no grupo... Yara: Eu falo rápido, e falo devagar aqui.

Pesq.: Isso. Ia te perguntar você já percebeu isso? Por que você acha?

Yara: É que eu tô calma essa semana.

A partir dessa fala, é possível construir um indicador de que Yara reconhecia a presença das emoções na manifestação de seus comportamentos, principalmente a fala acelerada, o que não se relacionava diretamente com os sintomas do transtorno. Logo, a adolescente não se assumia com o TDAH, a partir de uma compreensão de diversas emocionalidades na origem de muitos sintomas que a caracterizava com o transtorno. A análise das configurações subjetivas de Yara nos possibilitou compreender a complexidade da dinâmica subjetiva da adolescente, além das características que a rotulavam como TDAH.

Destacamos alguns tópicos importantes no caso de Yara, a saber:

1) A dinâmica subjetiva de Yara. Ao analisarmos as configurações subjetivas de Yara, percebemos a complexidade de seus comportamentos, o que nos fez refletir sobre a relação deles com sintomas biológicos, provenientes do transtorno. É possível observar a dinâmica subjetiva complexa, na qual os comportamentos da adolescente eram manifestações de processos simbólico-emocionais, que se expressavam em ações concretas. Verificou-se a família, com destaque para a situação financeira e os 
relacionamentos da mãe, e a aprendizagem como núcleos de sentidos subjetivos importantes, que estavam implicados na manifestação de "sintomas", eram interpretados como sendo TDAH, mas que não foi possível confirmar.

2) O posicionamento pessoal no processo de aprender. As dificuldades de aprendizagem de Yara se manifestavam além de comportamentos rotulados pelo diagnóstico, a partir da complexidade que envolve a configuração subjetiva desse processo. Dessa forma, é importante destacar o envolvimento na aprendizagem como uma função do sujeito que aprende, tendo um destaque o relacionamento com o professor e as motivações, que se relacionam com os diversos sentidos subjetivos produzidos durante a ação do aprender, implicados na história de vida e experiências de cada sujeito.

Assim sendo, a construção dessa análise foi de grande relevância para nos ajudar a perceber como o TDAH se configura em um sujeito concreto. Porém, apesar dessas considerações, o comportamento de Yara era visto pela maioria das pessoas como sendo uma representação de um transtorno de causa orgânica. Muitas vezes, diagnostica-se equivocadamente sem buscar compreender a dinâmica subjetiva de cada pessoa. Tal situação nos faz questionar se os sintomas que caracterizavam e rotulavam Yara como adolescente com TDAH, tinham origens biológicas, ou se na verdade, eles se manifestam como produções subjetivas de um sujeito em relação ao seu contexto de vida e história. E a partir disso, a solução para essa questão não tem como foco algo externo à pessoa, como por exemplo, o uso de Ritalina, mas principalmente as relações sociais. As ações de acolhimento e valorização da pessoa favorecem processos de produção de recursos subjetivos que estimulam a emergência do sujeito nos processos de dificuldade de aprendizagem.

\subsection{Caso George}

\subsubsection{Caracterização e construção do cenário de pesquisa}

George*, adolescente de 16 anos, nasceu em Brasília. Reside com a mãe, o pai e mais um irmão. Ele mora um pouco distante da escola, mas ainda é na mesma cidade satélite. Porém, tem dificuldade com transporte público, por isso acorda diariamente às 
5h da manhã e, apesar disso, algumas vezes chega atrasado por causa do ônibus. No final da aula, disse que fica um pouco na pracinha com os amigos, depois vai para a casa da avó ou de amigos que moram próximos à escola. Ele chega a sua casa por volta das $14 \mathrm{~h}$, às vezes, não almoça, porque prefere lanchar. À tarde, gosta de ouvir música e dormir. À noite, fica em casa vendo TV e conversando com os pais, às vezes vai à igreja. Dorme depois de $01 \mathrm{~h}$, porque geralmente tem insônia. No final de semana, realiza atividades com os amigos e vai à igreja.

Atualmente George cursa o $8^{\circ}$ ano do Ensino Fundamental na escola pública regular de ensino onde foi realizada a pesquisa. Já estudou em outras escolas públicas, em uma escola classe e depois foi para outra escola de Ensino Fundamental. Nessa escola, disse que aconteceu um fato, quando ele estava no $6^{\circ}$ ano, o qual será relatado posteriormente, que o fez ser transferido para a escola atual, apesar de não ter culpa no acontecimento, segundo ele. Durante esse período do $6^{\circ}$ ano nessa escola, ele conta que faltou muito devido ao que aconteceu, o que o fez reprovar. Ao ser transferido para a escola atual, fez o $6^{\circ}$ ano novamente, depois o $7^{\circ}$ ano, no qual reprovou uma vez.

Durante o grupo, George chamou atenção pelos relatos que ele fazia, envolvendo reflexões e histórias com base em algumas experiências vividas, que geralmente envolvia processos de mudança dele. $\mathrm{O}$ adolescente era um dos mais participativos no grupo, gostava de conversar e fazer brincadeiras e piadas, sempre muito alegre e sorridente, dificilmente faltava um encontro. Além disso, outra questão de destaque observada em George foi a maneira afetiva como tratava seus colegas no grupo, sendo bastante solícito e com atitudes acolhedoras e motivadoras, principalmente quando percebia que alguém estava triste. Nos momentos de discussões entre os participantes, geralmente as proposições de soluções partiam dele. Os instrumentos escritos também foram outro fator que contribuiu para a escolha de George como participante da pesquisa, a partir de colocações interessantes que despertaram o interesse da pesquisadora. Ao ser convidado para participar da pesquisa, ele demonstrou alegria e disponibilidade. E assim, realizamos os encontros individuais, no qual em todos George era muito receptivo quando eu chegava e estava sempre sorrindo. 


\subsubsection{A subjetivação do rótulo de TDAH e a dinâmica subjetiva}

George relatou por diversas vezes no grupo e durante os diálogos sobre uma experiência preconceituosa vivida por ele na escola onde estudava anteriormente, da qual foi expulso pela situação, apesar de não ter culpa, segundo ele. Contou que um dia, uma menina levou uma faca para tentar matá-lo, porque não aceitava o jeito dele, por ser "gordo, negro e pobre”. E ainda disse "[...] ela me matou por dentro, por dentro ela me matou [...]". No complemento de frases ele colocou "É difícil... sofrer preconceito”.

A experiência constituiu-se como algo significativo para George, estando implicada na produção de sentidos subjetivos relacionadas ao desejo de ser aceito e compreendido, que se manifestam, por exemplo, em relação à palavra “diferenças". Em um momento no grupo, como já foi relatado, durante a "Atividade das Histórias", a TO perguntou o porquê a história não tinha tido sentido, e ele respondeu "porque somos diferentes". Outro elemento associado à palavra foi quando ele a citou, ainda relacionando com a experiência:

"[...] as pessoas não compreendem que ninguém é igual aos outros, não aceita as diferenças, e isso é muito chato pra gente. Eu tenho orgulho de ser preto, gordo, do jeito que eu sou, mas assim, as pessoas ao nosso redor não compreendem isso, não têm a mesma mentalidade que a gente tem de falar assim ' Não, ninguém é igual, todos são diferentes'[...]”. (George, sistema conversacional).

A partir desses elementos, podemos ter um indicador do preconceito como um forte elemento na produção de sentidos subjetivos relacionados ao desejo de ser compreendido e aceito, que participam da configuração subjetiva em relação à figura do "outro", constituindo a subjetividade de George. Observa-se um indicador da presença da tensão entre ser o que ele é e o que queriam que ele fosse, que se relaciona com o desejo de ser aceito e compreendido perante os "outros". No complemento de frases, ele escreveu: "Fico com raiva... quando não posso ser quem eu sou”. Ele relatou que fica chateado quando tem que se adaptar a algum contexto e não pode ser quem ele é de verdade e por isso adota posturas para corresponder às demandas de um espaço social, citando como exemplo a sala de aula.

“[...] Tem muitos professores que não gostam de mim, porque eu sou muito de brincar, rir... e eles acham que 
eu tô brincando com a cara deles, fazendo chacota, mas é meu jeito, entendeu? Aí eu tenho que mudar o meu jeito por causa de uns professores, pessoas, pra mostrar que eu sou bom (George, sistema conversacional)."

A frase do instrumento escrito e o relato permitem-nos compreender o conflito vivenciado por ele a partir da tensão nos processos de subjetivação nos espaços individual e social. George apresentava características, como ser brincalhão, que não podiam ser expressas em determinados contextos, o que causava um conflito em relação a sua identidade, entre expressar quem ele realmente era, ou aquilo que os outros queriam que ele fosse. González Rey (2011b) define a identidade como um sistema de produção de sentidos subjetivos relacionados a processos e fatos, que possibilita, apesar das circunstâncias, sentir que somos nós mesmos. Assim, o relacionamento com o "outro" constitui-se um importante núcleo subjetivo para George, que se manifesta em sua subjetividade.

George, em muitos momentos durante o grupo, demonstrava preocupação em relação aos outros, sendo solícito e acolhedor quando percebia que alguém estava triste ou precisava de ajuda para realizar alguma tarefa. Além disso, pedia desculpas por várias vezes, quando achava que alguém tinha ficado triste por algo que ele tinha feito. A preocupação com os sentimentos dos outros e de fazer com que eles se sentissem bem constituem elementos da subjetividade de George, conforme também podemos observar nos instrumentos escritos:

3 coisas que menos gosta de fazer: deixar as pessoas tristes, brigar com as pessoas [...] 3 medos: perder as pessoas que eu amo, [...]

3 palavras que descrevem quem sou: amoroso [...] (George, instrumento "3 coisas").

"Fico feliz... quando todos em minha volta estão bem." "Odeio... deixar as pessoas tristes",

"É fácil... amar as pessoas". (George, complemento de frases).

Observa-se a preocupação com o outro como indicador de sentido subjetivo, a partir de alguns relatos feitos por George em situações distintas, tanto durante o grupo como nos sistemas conversacionais. São eles:

"Eu sou muito assim, emotivo, se a outra pessoa tiver triste eu fico triste junto com ela [...] Eu sou muito 
preocupado com as pessoas ao meu redor, assim, se tá bem, entendeu [...]".

"[...] o bullying, eu sinto o que a pessoa está sentindo, porque eu já passei por isso."

"Eu sinto (pausa), quando faço uma coisa que a pessoa fica triste comigo, eu me sinto culpado, e se alguém faz algo comigo, também me sinto culpado. É estranho [...]." (Relatos de George durante o grupo e sistemas conversacionais).

A preocupação e o cuidado em relação ao "outro" e o desejo em ser compreendido e acolhido também se manifestam na sua configuração subjetiva quando se relacionava com sua família. George relatou que a mãe sempre confiou nas capacidades dele, principalmente em relação à aprendizagem, apoiando-o em suas decisões, porém o pai não tinha esse pensamento, mas conta que aos poucos ele foi mudando por incentivo da mãe.

\begin{abstract}
"Igual meu pai, ele já falou muito que eu não ia conseguir, que eu não era capaz. Mas do outro lado tinha minha mãe, que sempre falava assim 'Eu acredito em você, você vai conseguir, você consegue'[...]. Acho que o maior apoio que você tem que ter é da sua família, porque se você não tiver o apoio da sua família, de quem você vai ter ?[...]" (George, sistema conversacional).
\end{abstract}

O ambiente familiar pode ter se configurado como um espaço favorável, o qual estimulou que George produzisse sentidos subjetivos relacionados à segurança acolhimento e credibilidade em relação à suas capacidades, conforme o relato e a frase "Minha família... é à base de tudo na minha vida" (George, complemento de frases). Assim, podemos ter um indicador de que os sentidos subjetivos produzidos por George em relação à família se estenderam para outros espaços e sistemas de relações.

Os sentidos subjetivos em relação ao desejo de ser aceito e compreendido também se expressam no desejo da concretização de espaços coletivos que favoreçam esses sentimentos, o que também se relaciona com a preocupação com que os outros também vivenciem essas situações. Por exemplo, no complemento de frases, ele escreveu "Se pudesse mudar algo, mudaria... a situação do mundo”. Quando questionado sobre a frase, relatou que queria mudar, dentre outras coisas, "a tristeza do mundo e os padrões da sociedade”. No instrumento desenho livre, com o título "O mundo ideal”, George fez 
pequenos desenhos como flores e grafou, de forma expressiva, as palavras: viver, paz, feliz, amor, sorrir (Apêndice C).

A amizade se apresenta como outro núcleo subjetivo importante constituindo-se como um sistema de relação em que aparecem sentidos subjetivos relacionados a apoio e compreensão.

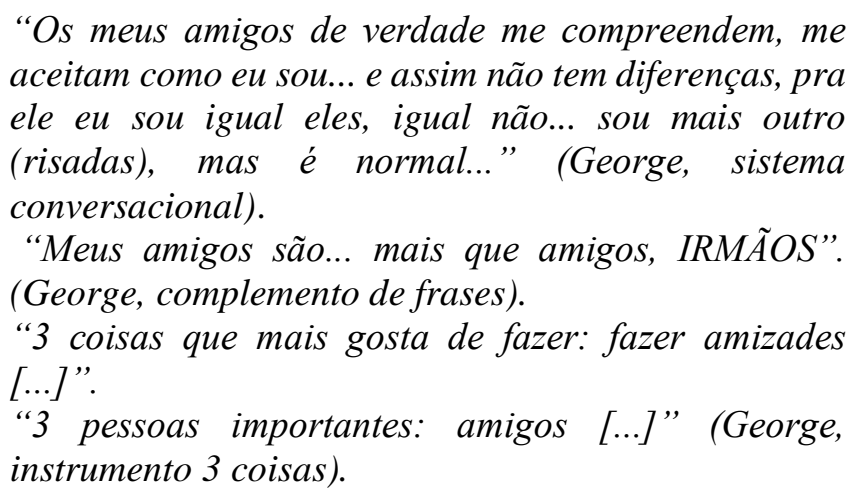

\section{Pode-se ter um indicador de que o cuidado expresso na relação de George com} a figura do outro se relaciona com a necessidade de ser reconhecido e compreendido, a partir de relações e espaços que favoreçam sua expressão. Em um momento no grupo, ele relatou: "eu choro, sou sentimental. Antes guardava para mim, é horrível, parecia que tava morrendo”. E depois, durante o diálogo, repetiu:

"Ah o que você fazer comigo, vou fazer com você", Eu comecei a parar e comecei a guardar pra mim, tudo que falava pra mim eu absorvia pra mim, e isso me deixava muito chateado, eu chorava muito... Até eu entrar aqui (sala recursos), e conhecer as pessoas e me abrir pra elas, e isso é muito bom, você saber conversar com uma pessoa e ela te entender, te compreender, o que tá passando... te ajudar... [...] É, eu achei o que faltava na vida. [...]. (George, sistema conversacional, sobre a sala de recursos).

$\mathrm{Eu}$ acho todos os TDAHs tinha que ir pra um lugar assim, entendeu? Porque é um espaço da gente, da gente mostrar quem a gente é, se abrir, conversar com as pessoas, e é ótimo" (George, sistema conversacional, relato sobre o grupo terapêutico).

Os relatos se constituem como elementos que apontam para a necessidade de George em ser compreendido e acolhido, como sendo um "grito de socorro", a partir de relações sociais que o estimulem a se expressar. George conta que encontrou esse 
ambiente favorável no espaço da sala de recursos pedagógicos e de forma mais recente no grupo de Terapia Ocupacional, onde segundo ele, foram espaços que o auxiliaram em um processo de mudança. No complemento de frases, ele escreveu que "No grupo da TO... é o lugar perfeito, onde você pode se expressar, ser quem você é de verdade".

Entretanto, disse que no começo teve resistência em participar desses espaços, da sala de recursos e do grupo terapêutico, o que foi notável nos primeiros encontros do grupo. Quando a TO perguntou sobre o porquê de estarem ali, ele falou, em tom de brincadeira, que era "tranquilo, calmo e muito quieto e não sabia o porquê que estava ali”. Outro elemento dessa resistência em participar do grupo está na expressão que ele falava constantemente nos primeiros encontros: "O que estou fazendo aqui? Não sou nada do que vocês falam”. Em certa ocasião, após finalizar um jogo, a estagiária estava explicando que foi necessário ter atenção para concluí-lo e falou sobre o TDAH e a falta de atenção. George, por ter acertado muitas questões do jogo, respondeu "Então, não sou $T D A H$ '. A partir desses elementos, temos um indicador que a configuração subjetiva do transtorno para George naquele momento estava permeada de sentidos subjetivos relacionados à incapacidade em ter êxito em algumas tarefas devido às limitações do transtorno, levando à negação do diagnóstico, que se relaciona com um desejo em mostrar que era capaz para ser aceito perante os outros. Nos primeiros encontros grupais, ele questionou: 'O que eu to fazendo aqui?' e disse que não queria ter continuado no grupo. Porém, afirmou que valeu a pena não ter desistido, pois o espaço ajudou-o muito, “as pessoas compreendem e tentam ajudar, sem recriminar por atitudes erradas"(George, sistema conversacional). Ele disse que no início achava que o grupo iria ser chato, mas as pessoas e atividades o foram conquistando, concluindo que atualmente "ama o grupo". Quando não tinha algum encontro semanal, ele relatava que sentia muita falta. Certa vez, durante o grupo, questionou a terapeuta por que os encontros aconteciam semanalmente, pois ele queria que fossem duas ou três vezes na semana. Verifica-se, dessa forma, que as relações sociais construídas nesse espaço, com base em atitudes de compreensão e acolhimento favoreceram processos subjetivos que permitiram a George se expressar de forma autêntica, sem ser recriminado por suas atitudes.

"As pessoas que estão lá (grupo) compreendem a gente entendeu? Sabe do nosso problema e tentam ajudar, não piorar a situação, eles falam assim 'Ah não, faz isso, entendeu? Esse lado não é certo, faz isso [...]' quando é outra pessoa: ' Você tá errado, você não faz 
nada certo entendeu? '. Lá (grupo) eles compreendem a gente, se tiver errado eles ajudam e não julgam, entendeu? E até as pessoas que estão participando (George, sistema conversacional)".

Esse ambiente também é observado na configuração subjetiva social do espaço da sala de recursos, que produz sentidos subjetivos para George, relacionados com a configuração do espaço familiar e associados a acolhimento, apoio, compreensão, atenção, carinho, entre outros. Essas hipóteses se reafirmam quando ele compara esse espaço a uma família, conforme citado no discurso seguinte, e complementa relacionando o papel da professora desse espaço como uma mãe, pois diz que ela sempre acreditou e confiou nele, aceitando-o com suas características. "3 pessoas importantes: sala de recursos" (George, instrumento 3 coisas).

\begin{abstract}
"A sala de recursos... é como se fosse, é parte da sua família, entendeu? Porque, pelo menos aqui, algumas pessoas que estão aqui me compreendem, me entendem, sabe do que eu sou capaz, me ajudam, acreditam que eu sou capaz... e isso ajuda muito, é como se fosse uma família mesmo. É uma família" (George, sistema conversacional).
\end{abstract}

Podemos compreender que muitos comportamentos de George indicava o desejo em ser sujeito, de mostrar que é capaz, mas que muitas vezes estava encoberto pelo rótulo da incapacidade relacionado ao diagnóstico e na falta de pessoas que acreditassem em suas capacidades. George relatou que acredita que a partir do momento em que ele encontrou esses ambientes, ele conseguiu ter um autoconhecimento, favorecendo mudanças em seu jeito de agir e pensar, principalmente em relação à suas capacidades e o modo de agir com os outros.

\footnotetext{
"Agora eu consigo lidar, consigo me controlar. 'Eu posso, eu consigo'. Não preciso de Ritalina para ficar quieto. Aconteceu muita coisa (fala sobre na escola ligarem para os pais dele direto, ir para a direção) [...]. E eu só queria mostrar que eu posso ficar quieto, hoje eu consigo me controlar mais" (George, sistema conversacional).
}

Com esses elementos, observa-se um indicador da importância dos espaços sociais que ele frequenta, a partir dos vínculos afetivos construídos nas relações, 
possibilitando processos de expressão e reflexão. Dessa forma, destacamos a relevância dos espaços e relações na configuração subjetiva do transtorno para George.

"Todo TDAH devia ter uma pessoa que acreditasse nele, porque ajuda muito a gente, porque muitas vezes a gente fica assim 'Eu não vou conseguir porque eu não sou capaz, eu não posso fazer aquilo'. E não é assim, entendeu? TDAH não é uma doença, é uma coisa que você tem que aceitar que você tem. Você tem que compreender, e assim, se você tem uma pessoa do seu lado pra te compreender, fica bem melhor, fica bem mais fácil de você entender as coisas. Igual, depois que eu entrei pra sala da Carla (professora sala de recursos) eu mudei muito mesmo, só me ajudou" (George, sistema conversacional).

Os sentidos subjetivos produzidos por George no grupo e na sala de recursos se desdobram na produção de novos sentidos subjetivos relacionados à capacidade que integram o seu posicionamento atual em relação ao transtorno, que se manifesta, por exemplo, no uso da medicação. Segundo George, ele foi diagnosticado há algum tempo com o TDAH, porém conta que nunca lhe foi prescrito o remédio. Nos primeiros encontros do grupo, ele falava de forma recorrente sobre o desejo de tomar Ritalina. Além disso, indicava que precisava do remédio para ficar mais quieto e não reprovar. Porém, alguns meses depois, durante o nosso diálogo, questionei-o sobre o desejo de tomar o remédio.

Pesq.: George, no grupo você falava constantemente que precisava de remédio para você passar de ano, porque não conseguia se concentrar. Você conseguiu o remédio?

G.: Não, não consegui, mas aprendi, em vez de usar um remédio, eu aprendi a me conhecer de verdade, a me controlar entendeu?

Pesq.: Mas então você não sente mais falta do remédio? G.: Não, eu não sinto, eu aprendi a me conhecer e me controlar, a me aceitar né? Do jeito que eu sou.

Verifica-se, portanto, a relação estabelecida por George entre o reconhecimento de que não precisava mais do remédio por acreditar em suas capacidades, não carecendo de recursos externos para lidar com o transtorno. George, então, passa a relatar sobre o TDAH não como algo que o limita em suas capacidades ou em seu desejo de fazer algo, mas como uma característica, desejando ser aceito dessa maneira, conforme alguns trechos ditos por ele: 
"Eu acho que eu tenho TDAH e eu me aceito, entendeu? Não é porque eu tenho TDAH que eu não posso fazer alguma coisa, não, eu posso... sou um ser humano normal como qualquer um do mundo, só tenho uns neurônios mais (risadas)". [...] "Então acho que o TDAH é só uma coisa que não vai mudar nada, no caráter da pessoa, no jeito da pessoa, só muda que a pessoa é mais acelerado que os outros [...] Eu me aceito do jeito que eu sou. O pessoal fala que TDAH é doido. É, eu sou doido mesmo" (George, trechos do sistema conversacional).

A partir desses posicionamentos de George, provoco-o em relação ao diagnóstico. Interrogo-o diante de todas essas questões, se mesmo tendo o diagnóstico, ele realmente achava que possuía o transtorno e ele responde: "É eu já pensei nisso, um exemplo, se eu não soubesse que era TDAH pra mim eu ia estar normal. Então pra mim, tendo o diagnostico de TDAH ou não, eu sou normal, igual qualquer outra pessoa.". Esse trecho unido aos outros elementos nos permite obter um indicador da posição de George como sujeito perante o TDAH, a partir da aceitação e compreensão de suas capacidades, responsabilizando-se por suas atitudes, independente do diagnóstico.

O posicionamento de George como sujeito perante o transtorno se desdobrou na produção de novos sentidos subjetivos em relação à desistência e ao preconceito. Ele conta que ao acreditar mais em suas capacidades, aprendeu que não pode desistir do que ele quer, principalmente dos seus sonhos. No complemento de frases, escreveu "Meu maior sonho é... realizar todos os meus sonhos", cujo primeiro é proporcionar uma vida melhor para a família dele, através do cuidado; e o segundo, é ser cantor. A partir dessa compreensão, ele percebe que para os sonhos se realizarem dependem de atitudes dele e não de acontecimentos ou causas externas.

"Se eu quero eu vou conseguir, porque desistir não vai adiantar nada, vai dar nada com nada... você vai desistir vai parar... e se você quiser mesmo, você vai continuar, tentar, vai ficar em lugar ruim, vai, mas vamos tentar de novo, vai errando, vai tentando acertar ...até uma hora vai dar certo" (George, sistema conversacional).

George passa a não se vitimizar em suas atitudes, adotando a postura ativa na construção de caminhos alternativos que o permitem alcançar seus objetivos. Além disso, também podemos observar a produção de novos sentidos subjetivos no relacionamento com o outro, em relação a ser aceito e compreendido, que se manifesta, por exemplo, na 
configuração atual entre ser quem ele é e as situações de preconceito. "É, hoje eu compreendo que eu sou capaz de mudar, de ser quem realmente eu sou [...]" (George, sistema conversacional).

Atualmente, conta que ainda sofre alguns comentários e atitudes preconceituosas, porém disse que a partir de um processo de reflexão, essas situações não o afetam mais como antes. Portanto, apesar das situações contextuais muitas vezes não terem modificado, evidenciam-se processos de mudança em George que lhe possibilitaram vivenciar as mesmas situações de uma maneira diferente. Conforme aponta González Rey (2007b), os principais recursos de mudança estão nos próprios sujeitos.

As novas produções subjetivas geram implicações em outros contextos, como por exemplo, na configuração subjetiva diante da aprendizagem de George. Ele começa a se reconhecer em diferentes espaços e a se posicionar de maneira diferente, o que pode ser o início de um processo de ser sujeito nesse contexto. No complemento de frases, relatou: "Quando não consigo aprender, eu me sinto... que não posso desistir”.

Porém, apesar do início da mudança de posicionamento de George perante a aprendizagem, destaca-se a relevância das relações sociais para o adolescente. Em relação ao espaço da sala de aula e ao contexto escolar de maneira geral, George relata sobre a insatisfação e um desejo de mudança das atitudes e relacionamentos dos professores e diretores perante os alunos, com base em ações mais compreensivas.

"Minha escola... não é tão legal.

Meus professores... são competentes

A escola perfeita seria... uma escola que compreendesse os alunos que têm 'TDH',. (George, Complemento de Frases).

Com base nos instrumentos, observa-se a contradição em relação aos professores da escola. Em uma frase, ele reconhece a competência, provavelmente pedagógica, dos professores, porém dentre as três coisas que mudaria na escola, de acordo com o instrumento "3 coisas", escreveu: "alguns professores e diretores". 
Ao ser questionado sobre essa mudança, ele ressalta a necessidade de que os professores e diretores possam compreender e aceitar as diferenças, principalmente em relação aos alunos diagnosticados com TDAH.

" $\mathrm{Eu}$, eu sofro muito preconceito na escola e acho que isso não é legal. E a atitude dos professores, diretores tinha que ser diferente por causa disso, mas não são diferentes. Eles acham que é uma brincadeira de adolescente normal, que não vai afetar na gente $[\ldots .$. " (George, sistema conversacional).

Os sentimentos de George indicam mais uma vez o desejo de ser compreendido e acolhido, e também se manifestam em relação à aprendizagem. Certa vez no grupo, a TO perguntou sobre como eles estudavam para a prova e ele respondeu: "quando tem alguém escutando". George conta que, em sala de aula, percebe que muitos professores não buscam compreendê-lo, quando ele não entende algum conteúdo.

"Se você falar assim, 'ah professor, eu não sei isso. Ah
você não sabe por que não estudou. ' fica julgando [...].
Seria muito melhor, não só na sala de recursos, mas os
professores entenderem que os TDAHs são assim é
difícil pra gente aprender... eles acham que é frescura
da gente, que a gente tá na sala de recursos só pras
pessoas ajudarem. E assim, a gente precisa disso, a
gente não tá fazendo só porque a gente quer. Igual, eu
não queria ser TDAH, a culpa não é minha... mas já que
eu sou, eu vou me aceitar do jeito que eu sou. E assim,
eles não compreendem. (George, sistema
conversacional)"
(Geme

Esse trecho se constitui como mais um elemento que permite reafirmar o indicador, conforme já citado, de que George passa a ter uma compreensão de que mesmo que haja implicações orgânicas devido ao transtorno (será que há?), não se constitui como limitação, sendo seu principal questionamento a falta de compreensão e aceitação das pessoas, nesse caso, dos professores. Ele cita que, devido a essas questões, tem dificuldade no relacionamento com alguns professores, o que gera dificuldades na aprendizagem do conteúdo da disciplina, conforme relato:

“[...] Atrapalha muito, porque assim é como se fosse um impedimento que a gente tem [...] porque se a pessoa não gosta de mim [...] eu fico mais na minha, quieto no meu lugar... e impede muito (George, sistema conversacional, em relação à aprendizagem)." 
Além disso, comentou sobre a importância de o professor estabelecer relações de aproximação com o aluno e a contribuição dessa ação no processo de ensinoaprendizagem:

“É. Ser mais assim, não ser 'Ah eu sou professor', mas ser um amigo, você pode falar assim 'Eu tô com dificuldade nisso aqui, me ajuda'. A maioria, você não tem a liberdade de falar isso, porque eles têm aquela imagem de professor durão e a gente tem que aceitar aquilo ali. Não pode se abrir. 'Professor, tô tendo dificuldade nessa matéria aqui'. Não pode" (George, sistema conversacional).

Porém, nos últimos encontros narrou sobre mudanças no relacionamento com os professores, pois acredita que eles o estão compreendendo melhor, sem julgá-lo por certas atitudes, o que facilitou a aproximação no relacionamento com alguns. A partir desses elementos, é possível evidenciar um indicador da importância das relações sociais, a partir de questões afetivas, na configuração subjetiva de George. Esse indicador se constitui também a partir do momento em que ele relata sobre o espaço da sala de recurso e um desempenho melhor de sua aprendizagem, a partir dos vínculos afetivos estabelecidos nesse contexto, conforme os elementos:

“[...] Eles (Carla e monitores) dão uma atenção maior pra gente entendeu? Eles veem que a gente precisa e não fica julgando 'Ah você não sabe' eles tentam ajudar a gente [...]" (George, sistema conversacional).

"A sala de recursos é... o melhor lugar pra estudar" (George, complemento de frases).

Observa-se, então, que as experiências vivenciadas e os espaços sociais, a partir das relações estabelecidas, têm grandes implicações na forma como o aluno configura a aprendizagem e se posiciona como sujeito nesse processo. Propomos alguns tópicos a fim de destacar pontos importantes observados no caso de George.

1) Configuração subjetiva de George perante o TDAH. Os sentidos subjetivos em relação à possibilidade de incapacidades, presentes na caracterização inicial do transtorno, entravam em conflito com o desejo de George de ser aceito e em mostrar que era capaz. Isso fazia com que ele não assumisse seu diagnóstico. Porém, no movimento subjetivo, a partir da produção de novos sentidos, ele passa a ver a necessidade de se 
reconhecer como um sujeito capaz que, independente da condição do transtorno, não o impede de tomar certas atitudes e lutar por seus sonhos.

2) As dificuldades de aprendizagem para além de aspectos orgânicos. A análise das configurações subjetivas de George leva-nos ao questionamento da existência do transtorno nele, pois percebe-se a complexidade subjetiva de seus comportamentos, com destaque para produção de sentido subjetivo em relação com à figura do outro, indicativa de importantes implicações nos processos de aprendizagem.

3) A relevância das relações sociais como espaços de expressão e reflexão. A dinâmica subjetiva de George apontou para o valor que as relações sociais tinham para ele. Assim, a partir da criação de vínculos em alguns espaços e relações, George pode se expressar e refletir sobre determinadas questões, gerando processos de produção subjetiva, que lhe possibilitaram adotar a postura de sujeito em certas ações. Portanto, as relações socias se constituem como um aspecto instigador de sentido subjetivo importante nos processos de desenvolvimento e aprendizagem de George.

Desse modo, esta análise tornou-se relevante para refletirmos como o diagnóstico de TDAH estava configurado subjetivamente em George, estando relacionado a um desejo de ser aceito e de mostrar sua capacidade, o qual se relacionava com experiências vivenciadas por ele. As relações sociais ganham ênfase no caso do adolescente e no modo como ele se relacionava perante as situações de dificuldades de aprendizagem. Destacamse determinadas mudanças dele perante o processo de aprender e em relação ao transtorno, que não estavam relacionadas diretamente com questões externas, mas a partir de um movimento subjetivo do aluno. Portanto, as questões de aprendizagem estavam além do transtorno, o qual não podemos constatar a sua existência orgânica diante da análise da dinâmica subjetiva de George.

\subsection{Caso Alice}

\subsubsection{Caracterização e construção do cenário de pesquisa}

Alice, adolescente de 12 anos, nasceu em Brasília- DF. Reside próximo à escola, na mesma casa com a mãe, porém no mesmo terreno há mais duas casas, onde, na primeira 
mora o tio e na outra, os avós maternos. Tem um irmão de 01 ano, por parte de pai, que não mora com ela. Os pais são separados. Conta que aos 05 anos de idade o pai dela foi preso, mas disse que o vê com frequência em finais de semana alternados, pois ele é liberado para passar o final de semana com a família e que também já foi ao presídio visitá-lo. Em relação à rotina, Alice estuda no período vespertino, então acorda por volta de $12 \mathrm{~h}$ e porque a mãe manda, senão, disse que continuaria dormindo. Depois vai tomar café da manhã e se arruma para ir à escola. Disse que não almoça. Ao chegar da escola, conta que gosta de brincar de boneca e mexer no tablet. Dorme por volta de $00 \mathrm{~h}-01 \mathrm{~h}$. Disse que não estuda e quando tem tarefa da escola, faz durante o horário de aula. Geralmente nos finais de semana em que se encontra com o pai, ela fica na casa da avó paterna. E durante esse período, algumas vezes vai à noite para festas de familiares, em casas próximas à residência da avó, porém nem sempre com o consentimento dos pais, retornando de madrugada para casa, segundo ela. Nos finais de semana em que não fica com o pai, geralmente vai para a casa de uma tia para brincar de boneca com a prima. Em relação ao seu histórico escolar, cursa o $6^{\circ}$ ano do ensino fundamental na escola pública em que foi realizada a pesquisa. Já frequentou três escolas: uma escola particular no período da Educação Infantil, depois, a escola classe, onde reprovou uma vez no $2^{\circ}$ ano do Ensino Fundamental, e a escola atual de Ensino Fundamental.

Desde o início do grupo, Alice chamou atenção pela forma afetuosa com que me tratava. Ela demonstrava afeto recorrente através de abraços, dizia que estava com saudades de mim e do grupo, pois às vezes ficava muito tempo sem os encontros. Além disso, ela gostava muito de conversar e praticamente em todos os encontros, antes ou após as sessões, ficávamos conversando sobre diversos assuntos, principalmente sobre a família e conflitos na escola, os quais ela iniciava espontaneamente, o que enriqueceu os momentos informais da pesquisa. Porém, outra questão que teve destaque em Alice foi o discurso recorrente durante os encontros grupais sobre situações de brigas e violências nas quais ela se envolvia na escola, o que aparentemente representa uma contradição, quando comparado a suas atitudes afetuosas. A construção do cenário de pesquisa com Alice foi ocorrendo naturalmente a partir de nossas relações e proximidade, o que facilitou a construção de vínculos, favorecendo a expressão dela inclusive com relação a assuntos delicados. Assim, após a breve análise dos instrumentos escritos, aliados a esses outros fatores, escolhemos Alice como mais uma participante da pesquisa. Durante nossos encontros individuais, a adolescente ficava visivelmente inquieta, uma vez ficou 
a maior parte do tempo rodando na cadeira giratória, na qual estava sentada. Além disso, mudava de assunto por várias vezes e de forma aleatória, ficando empolgada e contando detalhes de como tinha acontecido o que estava sendo relatado. O diálogo era interrompido várias vezes para que ela pudesse me mostrar alguma coisa: como desenhos, fotos, inclusive querendo ir até a sala de aula chamar uma amiga para eu conhecer. Era como se tudo o que ela estava me contando verbalmente tivesse que ser materializado em objetos físicos. No caso de Alice, buscou-se compreender as configurações subjetivas por trás da contradição entre seus comportamentos impulsivos e atitudes de violência física, que se manifestavam em seus discursos e ações.

\subsubsection{A subjetivação do rótulo de TDAH e a dinâmica subjetiva}

\section{Um núcleo de sentido subjetivo importante em Alice é o seu posicionamento} perante o transtorno. Ela acredita ter TDAH, porque diz que é muito inquieta e com muita energia. Citou que mesmo quando está doente corre bastante. Porém, disse que é normal ter o transtorno e tomar Ritalina, porque o remédio a ajuda a estudar. Ela disse que se aceita assim, não tendo o TDAH interferências significativas em sua vida, além dos estudos, conforme relatado por ela durante o sistema conversacional:

Alice: Assim, a gente tem mesmo e não pode fingir que gente não tem. Porque tipo, se a gente tem e falar que não tem... é igual ter diabete e falar que não tem e comer doce, passa mal mesmo....

Pesq.: Entendi. Então você acha que tem?

Alice: Tenho mesmo, eu não tenho vergonha... se eu tenho é porque minha avó ela era também TDAH, quem eu puxei... minha avó, minha mãe também tem uma tia com TDAH, minha mãe também era...

Pesq.: Mas você acha que te atrapalha em alguma coisa?

Alice: Não, eu só acho que me atrapalha nos estudos só isso.

Portanto, nota-se um indicador de que Alice se assume como sujeito em relação ao transtorno, o que está permeado de sentidos subjetivos em relação à aceitação e conformidade. Outro elemento relacionado a esse indicador é a posição de Alice em relação à medicação. Alice faz uso da medicação, porém disse que atualmente os remédios acabaram e a mãe estava tentando conseguir marcar consulta para conseguir a 
receita, o que não estava sendo fácil. Durante o grupo, por duas vezes a mãe procurou a mim e a Thaís para solicitar a marcação de uma consulta com a pediatra para conseguir a medicação. No entanto, até o último encontro Alice tinha dito que ainda não havia conseguido. A adolescente disse que acredita precisar bastante do remédio, mas que não vai ser pela falta dele que ela "vai deixar de viver"(Alice, sistema conversacional).

\section{A família aparece como um núcleo de sentido subjetivo importante para}

Alice, desdobrando-se na produção de sentidos subjetivos, que se manifestam em sua subjetividade. Na família, as brigas e o uso de bebida alcoólica aparecem como fortes elementos de produção de sentidos subjetivos.

\footnotetext{
"Tipo as pessoas da minha família, elas são legais e tal, mas às vezes tem muita briga, muita mesmo. Então aí acaba complicando e tudo [...].De vez em quando a gente bebe, porque assim, é costume do ser humano mesmo, beber, fumar... Mas na minha família tem gente que bebe mesmo...mesmo... Quando vai pra festa bebe mesmo[...](Alice, sistema conversacional)".
}

Nessa colocação, Alice também se inclui no uso das bebidas "a gente bebe". Em um momento no grupo, relatou para mim e para a TO que em certas festas de família começou a experimentar a bebida por incentivo de outros familiares. Também contou que o motivo da maioria das brigas na família é o uso da bebida alcoólica. Em outro momento no grupo, confidenciou de forma particular sobre alguns problemas com a prima e a tia dela, envolvendo uso de bebida alcoólica, drogas e agressões físicas. Após alguns meses, perguntei se já tinham solucionado os problemas da prima, ela disse que sim, mas que não queria falar sobre isso, só queria esquecer essa história.

Em certo dia no grupo, a partir de uma dica do jogo de adivinhações Perfil Júnior ${ }^{7}$, "Eu não tenho família", no qual o personagem a ser adivinhado era o Chaves, Alice comentou: “Eu não tenho família, não, eu tenho. Mas pobre, morador de rua não tem família. Ele foi fumar droga e não voltou mais (Alice, grupo de TO). Essa frase de Alice é interessante, pois primeiramente ela diz não ter família, depois ela mesma se corrige

\footnotetext{
${ }^{7}$ Jogo de tabuleiro de dedução e adivinhação. O objetivo é adivinhar uma coisa, pessoa, lugar ou ano, de acordo com algumas dicas descritas nas cartelas, que são lidas para os participantes ao decorrer do jogo.
} 
dizendo que tem, porém cita a figura do morador de rua, a condição financeira e o uso de drogas como elementos de abandono familiar.

As dificuldades financeiras da família também aparecem como um elemento que se destaca na sua configuração subjetiva, conforme observado no complemento de frases: "Eu queria... dinheiro". "Fico triste... eu quero uma coisa e minha mãe não compra". (Alice, complemento de frases).

Durante o sistema conversacional, Alice referiu-se a dinheiro por duas vezes: “ $O$ dinheiro na hora que você tá na mão, depois já não tá mais, ele é traiçoeiro [...]" I "A gente tem pouco dinheiro, não dá pra ficar gastando dinheiro com teatro, essas coisas [...]". No complemento de frases, ela anotou que "Se pudesse mudar algo, mudaria... muita coisa". Ao ser questionada sobre o que, por exemplo, ela relatou sobre a situação econômica do país, disse que mudaria o governo e diminuiria o preço dos alimentos.

Alice: [...] o desemprego gente, isso... tem gente que não tem pra comprar uma calcinha...sério. Tem um moço que mora perto da minha casa, ele é morador de rua tal, eu e meu avô sempre ajuda ele, porque, assim, eu não vou deixar uma pessoa passar fome, eu vendo aquilo, não vou deixar.

Pesq.: Ainda bem que você ajuda.

Alice: Ajudo, acho bem melhor ajudar do que a gente ficar olhando e vendo a pessoa sofrer...(Alice,sistema conversacional).

Nesse relato, surge novamente a figura do morador de rua e do personagem Chaves, através de um desenho livre dele feito por ela na aula de artes, que ela me mostrou durante esse diálogo. Ambas as figuras se relacionam com dificuldade financeira e abandono familiar. Assim, a ausência do pai, as brigas, o uso de bebida alcoólica e as dificuldades financeiras podem se constituir como fortes elementos de sentidos subjetivos que integram a configuração subjetiva dela, relacionando-se com a família. Esses elementos nos permitem construir um indicador da presença de sentidos subjetivos relacionados a abandono e necessidade de atenção na sua configuração subjetiva, que exercem grande influência na constituição da subjetividade de Alice.

No instrumento "3 coisas", ela escreveu três palavras que a descrevem: “Briguenta, malvada e legal”. Verifica-se que, ao mesmo tempo em que ela se considera malvada e briguenta, também é legal. Durante um diálogo ela me relatou que teve uma 
mudança na personalidade dela. Quando a questionei sobre o motivo, ela relacionou com a situação em que acreditava estar defendendo a amiga.

Alice: Tipo, antes se eu era aquela menina que andava só com o batonzinho rosa e tal [...] hoje eu já sou uma pessoa bem diferente.

Pesq.: Você se acha diferente? Como?

Alice: Uma pessoa, eu vou falar aqui, porque eu sou mesmo. Eu sou rebelde, chata, me intrigo com todo mundo...

Pesq.: Você acha? Por quê? Você tinha até colocado aqui que era briguenta, malvada... Por quê?

Alice: Eu me acho briguenta [...] (Relata um episódio em que queria proteger a amiga e quis usar da violência com outros colegas para isso) (Alice, sistema conversacional).

Alice descreveu sobre o episódio no qual quis usar a violência como forma de proteger a amiga, o que também pode indicar um sentimento de ciúmes. Contou que, certa vez, quis bater em alguns colegas, pois acreditava que em determinada situação eles estavam pressionando e deixando nervosa uma amiga dela. Esse episódio pode indicar o desejo de mostrar que era capaz de proteger os amigos e também estar vinculado a um sentimento de ciúmes em relação a eles e ao desejo de ser "útil" para mantê-los próximos a ela.

\footnotetext{
A configuração subjetiva em relação à família se desdobra na produção de sentidos subjetivos em relação à dependência emocional e proteção que se configuram no núcleo subjetivo das amizades. Um elemento que constitui esse indicador é a necessidade que ela tem de segurança e o medo de ficar sozinha sem amigos, sendo eles um refúgio e proteção. Em certa situação no grupo quando se discutia sobre violência e brigas na escola, Alice disse que no dia anterior falou para a mãe contratar um segurança para ela, porque não queria ficar sozinha na escola. E outra vez, de forma aleatória no encontro individual, contou que quando não tiver os amigos para protegê-la, contratará um segurança para ficar perto dela, porque assim estará protegida. Nas brigas, disse que antes tinha medo de apanhar, porém como agora tem a Kássia como amiga, não tem mais medo. "[...] eu às vezes tenho medo quando a pessoa é muito grande, mas agora eu não tenho mais medo, porque se vier me bater, eu chamo a Kássia. [...] Ela é ótima, alta, forte, e muito legal" (Alice, sistema conversacional).
} 
A adolescente também contou que bate nos meninos porque eles não poderão bater nela, já que ela é menina, "eu aproveito que sou mulher e bato neles”, porém faço a ela um questionamento: e se mesmo assim eles batessem nela? Ela me responde, "não, eles são meus amigos, eles não me batem "(Alice, sistema conversacional). A relação entre as amizades e se sentir protegida também pode ser observada no relato:

"Quando alguém fala que vai me bater, eu falo que não tenho medo de "perua" e nem "periguete". Quando falam que vão me bater, eu vou com meu "bonde". Eu tenho muitos amigos grandes". (Alice, grupo de TO).

Esses elementos apontam para um medo de ser agredida, de onde vem a necessidade de se sentir protegida pelos amigos. No instrumento "3 coisas", apontou que dentre as três coisas que tem medo é: dormir no meu quarto e ficar só. Contou que tem medo de dormir no quarto dela, pois fica sozinha e por isso dorme com a mãe. E o medo de ficar só, que foi escrito no instrumento, segundo ela, é o medo de ficar sem amigos.

“[...] é de ficar sem amigos. Sem ninguém... Não tem o Jorge da novela Carrossel? Ele é sem amigos... mas dá pra ver no rosto dele, que ele é triste porque não tem amigos, isso eu não gosto, eu não gosto de ficar sem amigos, eu gosto de ter amigos [...]" (Alice, sistema conversacional).

A amizade se constitui um núcleo subjetivo muito importante para Alice, conforme observado nos instrumentos escritos. As ações da adolescente permitem-nos ter o indicador de que a dependência emocional a faz querer manter os amigos próximos a ela, o que se manifesta em situações as quais ela demonstra preocupação e o desejo de protegê-los.

"Meus amigos são... (cita o nome de sete amigas)." "Amo... minha mãe e amigas" (Alice, complemento de frases).

3 pessoas importantes: amigas, mãe e pai.

3 mudanças na escola: o intervalo, quadra e os vidros quebrados (Alice, "3 coisas").

O último item, no qual Alice propôs três mudanças na escola, chamou-nos atenção, pois a partir do sistema conversacional percebemos que os itens descritos não se 
relacionavam com ela diretamente, mas principalmente com os amigos. Sobre o intervalo, disse que aumentaria a duração dele para os adolescentes comerem e se divertirem mais. Na quadra de esportes, mudaria principalmente o chão, porque disse que devido ao mato as pessoas podem se machucar com cacos de vidro. E queria arrumar as janelas quebradas da sala de aula colocando grades para evitar quebrá-las. Apesar de citar essas mudanças, Alice disse que não gosta de praticar esportes e que nunca se cortou com os cacos de vidro na escola, mas que a amiga dela já tinha machucado o pé, tendo que ir para o hospital. Essas mudanças propostas se configuram subjetivamente no núcleo das amizades, estando relacionadas com sentidos subjetivos associados à proteção.

Dessa forma, esses elementos levam-nos a perceber na subjetividade de Alice um indicador de que a necessidade de afeto e atenção se mascaravam em uma postura corajosa, defensiva e preocupada, a fim de manter as pessoas próximas à ela, o que se relaciona com o desejo de atenção e de mostrar que é capaz ("útil").

Outro elemento desse indicador é o desejo de Alice em ser alta para mostrar aos outros que é capaz de brigar. "Pois é. Tipo, as pessoas falam 'você não tem corpo, é magrinha, não consegue bater em alguém'. Mas quando eu estudava em escola pública, no $4^{\circ}$ ano, dei uma pisa em uma menina mesmo" (Alice, sistema conversacional). No instrumento desenho livre, com o título "O mundo ideal", Alice desenhou uma menina com salto alto e cabelo comprido (Apêndice D), quando pedi para me explicar, disse que era ela.

Pesq.: Porque você desenhou você?

Alice: Eu sou grande sabe, eu sonho muito em ser grande...

Pesq.: O mundo ideal é você ser grande?

Alice: É, eu ser grande, usar salto e botar um piercing no nariz $[\ldots .$.$] .$

Pesq.: E porque você queria ser alta?

Alice: Porque eu não aguento ser baixa.

Pesq.: Mas por quê? O que te atrapalha ser baixa?

Alice: Muita coisa [...] Pra brigar mesmo.

O desejo de ser alta e ser notada também pode ser observado na expressão "subir na mesa", dita por ela algumas vezes, em ocasiões diferentes. Uma vez no grupo, ela disse "mas tia, eu gosto de arrumar tumulto [...], eu bato na minha prima, eu subo na mesa [...]". Em outro momento, quando perguntei o que ela achou do grupo de TO , a 
primeira coisa que ela me contou foi que nesse mesmo dia, pela manhã no grupo, tinha subido na mesa durante um jogo para conseguir ver melhor. E quando estávamos conversando sobre alguns professores, disse que certa vez, em outra escola, como não gostava de um professor, ela e um amigo fizeram bagunça na aula dele, subindo na mesa e sambando.

Outro trecho, que também contribui para esse indicador, foi quando ela se referiu sobre a popularidade, após o término do namoro por ciúmes de outra menina: “[...] $A$ gente termina e fica com saudade, ainda, gostando da pessoa... Aí eu nunca pensei que a popularidade daquela menina popular, fosse atingir o coração dele, como eu atingi ”. Nesse trecho, percebe-se a dependência em relação a outras pessoas e o desejo de chamar atenção, sendo "popular", a fim de manter as pessoas próximas a ela, indicando um possível ciúme.

O término do relacionamento, o ex-namorado e a menina de quem ela sentiu ciúmes representam fontes importantes de sentido subjetivo para Alice, que tinha 12 anos e provavelmente estava vivenciando as emoções da primeira paixão. Durante os encontros do grupo, ela falava diversas vezes sobre esse namorado, José, o qual era muito citado como motivo das brigas em que ela se envolvia, por questão de ciúmes. Em um encontro do grupo, estava muito triste porque, segundo ela, tinha terminado com o namorado por motivos de ciúmes dele com outra garota, Márcia. Essa situação parece ter tido implicações significativas nas emoções de Alice, o que foi observado no seu discurso durante as sessões do grupo, nos encontros individuais e também no complemento de frases: "Odeio... José e Márcia" e "Fico com raiva... José”. A fragilidade emocional e a dificuldade de lidar com esses sentimentos podem ter levado Alice a procurar suportes para auxiliá-la com esses conflitos. Assim, disse que foi pedir oração para uma funcionária da escola para "tirar a paixão do coração dela" e que depois desse momento ela não sentiu mais nada.

"Fiquei muito feliz, porque aquele negócio saiu da minha cabeça, porque de manhã, de noite, eu chorava, chorava mesmo, dava pra ver que eu tava chorando pensando na pessoa [...]. Depois daquele dia (oração) eu não chorei, não derramei uma lágrima mais (Alice, sistema conversacional)." 
Após esse suporte emocional, Alice parece ter tido alguns pequenos posicionamentos perante as suas emoções em relação ao ex-namorado, mas associados à religião. Contou que José pediu para reatar o namoro, porém ela não aceitou, pois acredita que "é o inimigo mexendo com a minha cabeça e querendo ver chorar". Portanto, Alice não se assumia como sujeito nessa situação, não se responsabilizando por sua capacidade de controle e mudança em relação aos sentimentos. Tem-se um indicador de que, nas configurações subjetivas de Alice em seus relacionamentos com os outros, sobressaem-se a necessidade de afeto e atenção. E perante a possibilidade de perda, ela parece não conseguir se controlar emocionalmente, o que se manifesta pelo sofrimento emocional e atitudes agressivas.

A dificuldade de controle emocional, principalmente em relação à raiva, também se estende a situações para as quais ela relata não ter paciência de administrar o conflito. Assim, a falta de controle manifesta-se em ações impulsivas, como por exemplo, as agressões físicas, conforme percebido por ela.

Pesq.: [...] Parece que você não consegue se controlar, parece que quando você tá com raiva a primeira coisa que você quer fazer é...

Alice: Bater. Bater nas pessoas.

Pesq.: E se não tiver ninguém por perto?

Alice: Eu pego uma pedra e jogo na pessoa.

Em certas situações, ela relata que tenta fazer um esforço mental para se controlar, porém disse que o corpo dela tem um impulso de querer bater "minha mão fica 'tuc-tuc"”. Ela conta, por exemplo, que fica muito nervosa, "doida”, quando chega à sala de aula e estão todos chamando o nome dela ao mesmo tempo. Ela puxa os próprios cabelos. Durante o grupo, quando a TO perguntou como eles lidavam com a raiva, Alice respondeu: "Eu dou murros na parede, rasgo ursos [...] Adoro enfiar faca nos outros." Porém, ela parece ter consciência de outras atividades e recursos alternativos para manifestar o sentimento de raiva, sem ser a agressão física.

Pesq.: E quando você tá em casa, sozinha no seu quarto, quando você fica com raiva, você faz o quê?

Alice: Eu escrevo no meu diário [...] Quando eu estou com muita raiva eu vou lá. Quando não tem ninguém em casa, no barraco mesmo, eu vou lá pego o pau e bato três vezes no chão.

Pesq.: E passa a raiva?

Alice: Eu fico uma hora batendo lá, mas passa a raiva. 
Pesq.: E escrever no diário, também passa?

Alice: Passa. Pintar, fazer qualquer coisa assim, passa. Pesq.: Ah é? Desenhar, pintar [...] Você poderia tentar fazer mais isso, quando você tiver com raiva...

Alice: É. Só que na escola não tem como. Eu fico com raiva mesmo $[\ldots]$.

Percebe-se, portanto, que ela reconhece alternativas que a auxiliam no seu controle emocional, porém tem dificuldades de colocá-las em prática, principalmente no contexto da escola. Conforme citado nesse relato e durante outros discursos no sistema conversacional, Alice discorreu bastante sobre diversos hobbies, que de uma maneira geral, são atividades manuais e artísticas, as quais favorecem o desenvolvimento criativo e expressivo. Assim, essas atividades são outro núcleo subjetivo importante no caso de Alice, uma das principais é brincar com bonecas e confeccionar roupas e utensílios domésticos de brinquedo a partir de materiais recicláveis. Além das bonecas, também gosta de brincar de "produzir" as pessoas, com roupas, maquiagens e acessórios. Gosta de desenhar, principalmente roupas. Em um diálogo, comparou ficar tão calma quando desenha como quando toma Ritalina. Outro hobby é o de tirar fotos, principalmente dela e das amigas. Por várias vezes, mostrou-me diversas fotos no seu celular, incluindo também um vídeo que ela elaborou a partir das fotos. Outra atividade de destaque de sua preferência é o teatro. Tanto no grupo como durante a nossa conversa, falou sobre o desejo de se matricular em um curso de teatro. Por fim, também citou que gosta de dançar. Outro recurso de expressão dito por ela foi um diário, o qual utiliza para escrever seus "segredos" quando está com raiva, sendo essa também uma alternativa de expressão de sentimentos de forma não verbal.

Em um encontro, propus a ela que escrevesse em uma folha em branco, uma estratégia semelhante ao diário, para ser utilizada no contexto escolar quando ela sentisse raiva, evitando as agressões físicas. Ela disse que era difícil, porém iria tentar. No nosso último encontro, ela disse que ainda estava sendo difícil, mas que iria tentar novamente. Percebe-se em comum a natureza expressiva e criativa das atividades, a partir de elementos que nos permite construir um indicador de que as atividades podem representar para Alice recursos alternativos que favorecem um autocontrole diante dos sintomas de impulsividade e hiperatividade. As atividades de preferência de Alice se constituem motivações integradoras de sua configuração subjetiva na aprendizagem, que se manifestam, por exemplo, no comportamento distinto adotado 
perante a disciplina de artes e matemática. "É dificil... a matemática”. "Meu maior problema... MATEMÁTICA*”. "É fácil... artes” (Alice, complemento de frases).

Em relação à Matemática, disse que, apesar de a professora explicar bem, tem dificuldades no conteúdo. Durante um diálogo informal, porém, Alice me relatou sobre o que tinha acabado de acontecer na aula dessa disciplina, do qual a professora não tinha conhecimento. Disse que uma amiga bateu na cabeça do amigo dela e elas começaram a rir muito. Então, questionei-a sobre o que ela achava de situações como essa e se o ocorrido poderia ter relação com a dificuldade que ela tinha na aprendizagem da disciplina. Ela disse que acreditava nessa relação, pois perdia a atenção fácil e tinha dificuldades em se concentrar. De maneira geral, relatou que, além de matemática, também tinha essas dificuldades em outras disciplinas. Contou que em Artes, no entanto, era um pouco diferente. Ela disse que "ama" a disciplina, porque pode pintar e desenhar e, às vezes, durante a aula havia músicas e danças. Verifica-se que o interesse pela disciplina estava relacionado com as atividades de preferência de Alice, o que se constituía como uma motivação e se manifestava em seu comportamento na disciplina. Ela relata que na aula de artes prefere não sentar perto dos amigos que fazem as brincadeiras, por saber que dificulta a sua atenção e concentração, o que difere do comportamento durante a aula de matemática.

Segundo González Rey (2012, p. 127), os motivos são configurações subjetivas que se organizam no curso da ação. As ações diferentes de Alice em relação à aprendizagem estão, portanto, relacionadas às configurações subjetivas que funcionam como motivações nesse processo. Além disso, disse que também gosta da disciplina de artes, porque ela se "expõe" nas aulas, a partir de um espaço no qual ela pode se expressar. Esse relato, unido aos sentidos subjetivos produzidos no espaço do grupo de TO, na sala de recursos e na sala de aula, permite-nos construir um indicador de que Alice apresenta necessidade de ter espaços nos quais ela possa se expressar, sem ser recriminada por suas atitudes. No grupo da Terapia Ocupacional... eu sou doida”. "A sala de recursos é... especial" (Alice, complemento de frases)

Durante um diálogo, questionei o significado da frase em relação ao grupo com a terapeuta. Alice contou que no grupo de TO ela podia ser quem ela era fazendo as coisas de que ela gostava como conversar e correr, e isso significava ser "doida". 
Pesq.: E por que você acha que lá pode ser assim e em outros lugares não?

Alice: Porque em outros lugares as pessoas vão achar meio estranho eu fazer o que eu sou de verdade.

Pesq.: Ah entendi, e lá você pode ser o que você é de verdade?

Alice: Sim. [...] Me ajudou bastante, pra me mostrar quem eu sou de verdade.

Desse modo, os sentidos subjetivos produzidos em relação ao grupo de TO relacionavam-se com expressão e comunicação, que foram favorecidas pelas atitudes da profissional, conforme observamos no relato da adolescente: "Ela (terapeuta) deixava a gente se divertir, falar o que a gente [...] pôr pra fora... ela perguntava. Às vezes não tem isso na escola, só quando a gente vai pra Carla" (Alice, sistema conversacional). Os sentidos subjetivos em relação a esse espaço se desdobraram para outros contextos e relações, como por exemplo, a sala de recursos pedagógicos, com a professora Carla.

Alice: A sala de recursos é muito especial pra mim, porque tipo eu me sinto leve, voando... A Carla me ajuda bastante, é uma pessoa muito especial ela, gosto muito dela.

Pesq.: E porque você acha que lá é diferente na sala de aula? Você consegue aprender mais?

Alice: Consigo. Nas provas eu vou bem direitinho aqui na Carla, já na sala eu tiro nota muito baixa.

Pesq.: Ah é, porque será?

Alice: Porque eu não me sinto muito à vontade na sala de aula...

Alice conta que em sala de aula, às vezes, não se sentia bem, porque havia pessoas que criticavam as atitudes dela, e assim ela não poderia se expressar. Desse ponto de vista, destaca-se a importância de espaços sociais que estimulem processos de expressão e comunicação a fim de favorecer reflexões e posicionamentos, inclusive com implicações no contexto da aprendizagem.

Propomos alguns tópicos como resumo da análise do caso de Alice, a saber:

1) A relevância da família e dos amigos. A configuração subjetiva de Alice diante de sua família tinha implicações no seu relacionamento com os amigos. Nas amizades, percebem-se sentidos relacionados à dependência, necessidade de proteção, ciúmes, insegurança, entre outros que se manifestavam na subjetividade da adolescente. 
2) As implicações da dinâmica subjetiva nas ações agressivas. A análise das configurações subjetivas possibilitou compreender a complexidade das ações agressivas de Alice. Elas envolviam uma manifestação subjetiva, principalmente, relacionadas ao desejo de manter os amigos próximos e de chamar atenção, diante da sua dificuldade em controlar suas emoções.

3) As atividades como recursos para o controle emocional. Os sintomas do transtorno, principalmente a impulsividade, podiam ser observados nos comportamentos de Alice, e podiam ter origem orgânica, mas as análises subjetivas desses comportamentos adquiriu outra significação e relevância. Destaca-se a possibilidade das atividades de preferência de Alice, como por exemplo, o teatro e o desenho, se constituirem como recursos para o controle emocional e domínio do seu próprio comportamento.

4) As relações entre os espaços sociais e o processo de aprender. A aprendizagem aparece como um processo singular relacionado com as motivações de Alice, o que gera implicações no modo como ela se posiciona nesse processo. Além disso, a sala de aula, a partir das relações sociais participantes da subjetividade social, pode ser um espaço que não favorece a participação da Alice. O grupo terapêutico e a sala de recursos se constituíram como espaços favorecedores de expressão, que possibilitaram alguns processos de posicionamento mais ativo da adolescente.

Por conseguinte, a análise da dinâmica subjetiva de Alice possibilitou-nos compreender diversos fatores que estavam implicados em sua aprendizagem. Além disso, percebe-se que o motivo de determinados comportamentos e expressões, como por exemplo, a agressividade, fazia parte de um sistema amplo, envolvendo sua história de vida e principalmente o contexto familiar e as amizades. Assim, as situações de dificuldade de aprendizagem da adolescente se expressavam além das características orgânicas do TDAH. 


\section{6-ANÁLISE INTEGRATIVA DOS CASOS E CONTEXTOS E POSSIBILIDADES DE CONTRIBUIÇÕES DA TO NO ÂMBITO DA TEORIA DA SUBJETIVIDADE}

No primeiro eixo temático, objetivou-se contextualizar e tecer uma análise sobre dois espaços de participação dos adolescentes: o grupo terapêutico em TO e o ambiente escolar, onde se destaca a relação dos espaços com as possibilidades de emergência do sujeito. No segundo eixo temático, foco esteve voltado para a identificação dos aspectos intrísecos dos três adolescentes, que nos ajudaram a compreender como as dificuldades de aprendizagem estão organizadas em uma dinâmica subjetiva, com base em sua diversidade. Consoante o terceiro eixo, apresenta-se a análise integrativa realizada a partir dos contextos e dos três casos apresentados, para assim refletirmos sobre um modelo teórico das possibilidades de contribuições da Terapia Ocupacional, com base na Teoria da Subjetividade, para alunos com dificuldades de aprendizagem, no caso, TDAH, que é o objetivo deste estudo. Dessa maneira, as informações a seguir estão organizadas em duas partes: análise dos casos e contextos e possibilidades de contribuição da Terapia Ocupacional a partir das relações com a Teoria da Subjetividade.

\subsection{Casos e contextos}

As análises dos contextos terapêutico e escolar e a compreensão das configurações subjetivas dos três casos analisados permitiram destacar três pontos de análises, os quais serão melhores aprofundados. São eles: O sentido subjetivo do transtorno, o desejo de se sentir capaz e as relações sociais .

O estudo teórico das configurações subjetivas de Yara, George e Alice, com base nas contribuições da Teoria da Subjetividade, faz-nos questionar o valor heurístico do diagnóstico e dos sintomas do TDAH. As contribuições da Teoria da subjetividade permite-nos avançar além dos sintomas do diagnóstico. Segundo González Rey (2007a, p.164), “a patologia não é uma estrutura intrapsíquica individual, mas uma configuração subjetiva, que é uma verdadeira produção sobre a experiência vivida”.

Dessa forma, ao considerarmos a existência de sujeitos concretos, situados historicamente e contextualmente, sendo capazes de produzir uma diversidade de sentidos 
subjetivos de acordo com diversas experiências do cotidiano, pode-se refletir sobre o rótulo de TDAH e as dificuldades de aprendizagem. A maioria dos comportamentos manifestados pelos adolescentes estava vinculado aos sintomas do transtorno, porém esses "sintomas" tinham origens orgânicas ou se constituíam como manifestações de um sistema de configurações subjetivas? A análise das configurações subjetivas nos três casos permite-nos romper com a entidade universal dos sintomas do transtorno.

Assim, de acordo com Gonzaléz Rey (2007a), a diversidade de patologias expressam configurações subjetivas singulares, não sendo produzidas a partir da junção de elementos comuns, mas pela complexidade do sistema de configurações subjetivas qualitativamente diferenciadas. Dessa forma, é possível compreender que a caracterização do transtorno está além da soma de aspectos em comum, mas na compreensão de como esses "sintomas" estão organizados na dinâmica subjetiva.

Rossato e Mitjáns Martínez (2009) consideram que as dificuldades de aprendizagem escolar podem ser analisadas basicamente sob dois aspectos: primeiro, quando há efetivamente a deficiência nas funções biológicas que, ao serem somadas ao seu impacto social, podem comprometer as condições do aluno para acompanhar o ritmo e as exigências de aprendizagem estabelecidas pelo currículo escolar. Segundo, quando não há deficiência nas funções biológicas, mas a organização subjetiva do estudante constituída na dinâmica das ações e relações das diferentes zonas de sua vida, incluindo a escola, ao ser confrontada com o processo de ensino, não expressa condições favoráveis para dominar o sistema de conceitos científicos dentro do tempo e dos padrões avaliativos utilizados na instituição escolar.

A definição das dificuldades de aprendizagem, proposta pelas autoras, juntamente com os princípios da Teoria da Subjetividade de base histórico-cultural, também possibilita um rompimento com as determinações biológicas impostas ao desenvolvimento e a relação linear entre causa-efeito. Dessa maneira, mesmo que exista a origem biológica do transtorno em algum dos três casos dessa pesquisa, não é possível estabelecer o quanto ou como a pessoa irá se desenvolver e se relacionar com a aprendizagem a partir dessa condição. Conforme aponta Vygotsky (1997), o desenvolvimento acontece por caminhos singulares e alternativos construídos pelo próprio sujeito. Também, não se pode estabelecer uma relação linear entre determinada causa, como por exemplo, a família, os amigos, experiências vividas, aspectos cognitivos 
ou emocionais isolados como motivos das dificuldades de aprendizagem. A aprendizagem pressupõe a confluência de diversos fatores, organizados em uma dinâmica subjetiva complexa e singular. Conforme nos aponta Madeira-Coelho (2014, p.102):

"A aprendizagem precisa ser compreendida como função do sujeito que aprende que dá sentido subjetivo às situações que vivencia na coletividade, e dessa forma, configura processualmente as diversas $\mathrm{e}$ diferentes funções em uma singularidade que lhe é própria."

Evidencia-se, nos três casos analisados, a forma com que as dificuldades de aprendizagem estavam organizadas em processos de configurações subjetivas, que se articulavam com diversos contextos e experiências, assim como nas relações com o "outro". No caso de Alice, observa-se, de forma mais evidente, a possível presença da causa orgânica do transtorno, que se manifesta principalmente em sua dificuldade de concentração, hiperatividade e impulsividade, porém com relevantes implicações de elementos contextuais e de suas experiências na sua configuração da subjetividade ao se relacionar com o processo de aprendizagem. Em Yara, sobressai-se a relevância na configuração familiar, a qual se desdobrava em outros sentidos subjetivos que se configuravam em sua aprendizagem. E em George, verificam-se as implicações da configuração de sua subjetividade e do relacionamento com os "outros" no modo como sua aprendizagem estava organizada.

A complexidade da dinâmica subjetiva dos três adolescentes muitas vezes os impedia de se tornarem sujeitos em diversas áreas de suas vidas, o que se manifestava nas dificuldades de aprendizagem observadas na escola.

A partir disso, é possível compreender a complexidade que envolve as dificuldades de aprendizagem, estando além de características orgânicas ou de aspectos contextuais, mas principalmente no posicionamento do sujeito frente ao seu processo de aprender. Conforme destaca González Rey (2007a), compreende-se a 'patologia' como “estado no qual o sujeito perde sua capacidade geradora e não tem opções diante do impulso proveniente da configuração subjetiva” (p. 158).

Segundo o autor, a impossibilidade de o sujeito produzir novos sentidos subjetivos frente a uma situação que o afeta, coloca-se como o limiar entre saúde e "patologia", 
estando além dos limites concretos do defeito. Dessa forma, verifica-se que as dificuldades de aprendizagem precisam ser compreendidas a partir de um estudo da complexidade do sistema subjetivo. Coloca- se em destaque a negação da posição de sujeito nesse processo, e de condições que favoreçam ou não esse posicionamento no processo de aprender, independente da existência de causas orgânicas.

Dessa maneira, outro tópico de análise é o desejo de sentir-se capaz, observado nos três adolescentes analisados. A partir da compreensão das histórias e experiências vividas e do modo como elas estavam organizadas na dinâmica subjetiva de cada um, deduz-se, em muitas situações, a existência da negação da condição de sujeito, porém, em contrapartida, a presença do desejo de se sentirem capazes, de fazer algo, sem interferências externas. Esse desejo, entretanto, muitas vezes estava encoberto por espaços e relações que os impediam de se posicionarem, a partir de atitudes discriminatórias ou preconceituosas, geradoras de implicações no modo como eles se relacionavam com o transtorno. "Os sentidos subjetivos e configurações subjetivas da subjetividade social estão presentes na configuração subjetiva do transtorno" (González Rey, 2011b, p. 165).

Assim, por exemplo, George no início não se assumia com o diagnóstico, pois na configuração subjetiva do transtorno estavam implicados sentidos subjetivos relacionados à incapacidade, o que representava uma contradição com o seu desejo de mostrar que era capaz e de ser aceito perante os "outros". Contudo, as produções de novos sentidos subjetivos relacionados à capacidade, a partir de situações que favoreceram a emergência do sujeito, alteraram o modo com que ele passou a se relacionar com o transtorno.

De outra sorte, a condição de "assujeitamento" estava relacionada com a subjetividade social de vários contextos, principalmente do espaço escolar. Por exemplo, nos casos de Yara, George e Alice, observam-se situações no espaço da sala de aula, permeadas de atitudes ou comentários de outros colegas ou professores, que representavam barreiras para eles se posicionarem como sujeitos. A subjetividade social da maioria dos espaços em que eles frequentavam estava permeada de sentidos subjetivos relacionados à incapacidade deles serem sujeitos, vinculando-os aos rótulos do diagnóstico ou às próprias características deles. 
Segundo González Rey (2007a, p.155), o rótulo "leva á universalização de uma condição que define práticas sociais despersonalizadas em relação ao 'problema', perdendo de vista o sujeito que o expressa e os contextos e práticas sociais em que se gera", levando a situações de preconceito e exclusão. Por consequência, percebia-se que em certas circunstâncias eles queriam se posicionar para mostrar para eles mesmos, mas principalmente para os outros, que eram capazes de serem sujeitos, o que se relacionava com um desejo de aceitação social.

Os desdobramentos dos rótulos provenientes da subjetividade social geram implicações no modo como o adolescente com dificuldade de aprendizagem configura o seu processo de aprender e de ser sujeito em diversos espaços. Dessa forma, apesar de eles indicarem o desejo de ser capaz, de ser sujeito, algumas vezes eram desconsiderados e mascarados pelos rótulos que configuravam a subjetividade social de alguns contextos, não favorecendo o posicionamento dos adolescentes. Esse desejo encontra implicações com a importância das relações sociais na configuração subjetiva da aprendizagem, conforme observado nessa pesquisa.

Com base nessas considerações, outro ponto de análise importante em nossa pesquisa foram as relações sociais, visto as implicações desse aspecto nos sistemas de produção subjetiva. As questões observadas no contexto terapêutico, no espaço escolar e na dinâmica subjetiva dos casos, permitem destacar o papel do "outro" no desenvolvimento subjetivo dos adolescentes em diversas áreas de suas vidas. "É o 'outro social' essencial para o desenvolvimento intelectual, afetivo, social e de todas as outras dimensões e aspectos que integram o aluno como ser humano" (Tacca, 2004, p. 101). Muitas vezes, o modelo biomédico, centrado no diagnóstico e nos sintomas, desconsidera as implicações das relações sociais na configuração subjetiva do transtorno, o que se manifesta também no campo educacional, desconsiderando a importância das relações sociais nos processos de aprendizagem.

Destarte, a partir da análise dos casos e contextos, destaca-se o papel das relações sociais, com base no relacionamento com o "outro", na construção de espaços favorecedores, ou não, para a produção de sentidos subjetivos que possibilitem a emergência do sujeito. Os casos de George, Yara e Alice apontaram para a fragilidade em algumas relações sociais que, aliada ao desejo de mostrarem que eram capazes, indicava a necessidade de espaços e relações nos quais eles pudessem se expressar. Os espaços 
coletivos em que eles estavam inseridos, às vezes, impossibilitavam-nos de que fossem capazes de produzir sentidos subjetivos a fim de superar as dificuldades de aprendizagem. Então, para os três, o ambiente da sala de recursos e do grupo terapêutico, a partir dos relacionamentos estabelecidos, baseados em atenção, compreensão e acolhimento, representaram espaços de expressão e de comunicação, favorecendo processos de produções subjetivas.

Essa questão faz-nos concluir que às vezes as pessoas não têm muitas demandas, nem grandes "problemas" significativos, mas apresentam a necessidade maior de espaços favoráveis e interlocutores disponíveis para que eles possam se posicionar. Apesar de nesses espaços não necessariamente ter havido diálogos reflexivos, o simples fato da concretização de ambientes que favoreceram a escuta e expressão autêntica dos sujeitos representou contribuições para processos de autoconhecimento e reflexão, como se pode observar nas falas de Alice e George, que podiam ser "quem eles eram de verdade" no espaço do grupo.

"Porque em outros lugares as pessoas vão achar meio estranho eu fazer o que eu sou de verdade" (Alice, trecho do relato sobre o grupo).

"No grupo da TO... é o lugar perfeito, onde você pode se expressar, ser quem você é de verdade" (George, complemento de frases).

González Rey (2011b) destaca que o autoconhecimento e a reflexão são importantes ferramentas de produção subjetiva. Dessa forma, podemos perceber que a expressão autêntica possibilitou um autoconhecimento, gerando reflexões sobre suas capacidades e valores, permitindo o início de processos de emergência dos três adolescentes como sujeitos em determinadas situações.

Destaca-se o relacionamento com o "outro" na constituição desses ambientes como espaços favorecedores de produções subjetivas. As atitudes dos outros, que se expressam nas relações sociais, têm grande influência na configuração subjetiva e no desenvolvimento do posicionamento de sujeito perante o processo de aprendizagem e em diversas áreas de sua vida. No caso dos três adolescentes, evidencia-se essa questão, seja nas relações familiares ou em outros relacionamentos, na configuração subjetiva da aprendizagem e nas dificuldades enfrentadas nesse processo. Por exemplo, Yara tinha 
dificuldades de ler em público, pois quando gaguejava durante a leitura sofria comentários preconceituosos, o que evocava sentidos subjetivos relacionados à incapacidade, insegurança e vergonha na configuração subjetiva diante da aprendizagem, impedindo que lesse novamente. Porém, no espaço do grupo, essa mesma atividade foi realizada, a partir de um ambiente que propiciava acolhimento e atenção, estimulando que Yara realizasse a leitura. A ação executada nesse espaço pode ter contribuído para a produção de novos sentidos subjetivos em relação a essa atividade, gerando implicações no processo de aprendizagem e na realização da leitura também no espaço da sala de aula, que era uma dificuldade relatada pela adolescente. Conforme cita González Rey (2007a, p. 167), "no sentido subjetivo dos atos do sujeito em um espaço social concreto, estão contidos processos e consequências de outros espaços sociais que lhe afetam de forma simultânea". Dessa forma, verifica-se a trama dos espaços sociais nas configurações subjetivas e nos processos de desenvolvimento subjetivo dos adolescentes que participaram da pesquisa.

Em George, sobressai o relacionamento com os professores, e mais especificamente com Camila. Nota-se que, inicialmente, o relacionamento conflituoso com a professora produzia sentidos subjetivos que o impediam de se posicionar e de se desenvolver na relação com a aprendizagem da disciplina. Todavia, a partir da mudança nesse relacionamento, George passou a produzir novos sentidos subjetivos em relação à disciplina, que possibilitaram a reconfiguração subjetiva no processo de aprendizagem. No caso de Alice, o espaço da sala de recursos é referido como um ambiente favorável para sua aprendizagem, a partir do relacionamento com a professora Carla em contraposição ao espaço da sala de aula onde ela dizia ter dificuldades, pois não se sentia "à vontade" devido a algumas atitudes preconceituosas dos colegas.

Nas dinâmicas relacionais estabelecidas com a terapeuta ocupacional, com a professora Carla e com a professora Camila, em relação a George, detecta-se a produção de novos sentidos subjetivos, considerando que "toda relação autêntica está associada a processos de subjetivação" (González Rey, 2007a, p. 176). Logo, pode-se destacar a relação da aprendizagem e do desenvolvimento subjetivo a partir das relações autênticas estabelecidas nos espaços sociais que favoreçam produções subjetivas e estimulem o posicionamento do aluno como sujeito. 
Partindo dessas concepções, as "mudanças de comportamento" observadas nos adolescentes, citadas durante a pesquisa tanto por eles, como pelas professoras e pela terapeuta, representam dinâmicas subjetivas complexas, originária da confluência de fatores que se expressam em alguns posicionamentos diferentes deles. A terapeuta acredita que a principal contribuição do grupo foi a mudança de comportamento observada no relacionamento com os outros colegas, a partir da diminuição de conflitos e discussões entre eles. A professora Camila descreveu a mudança no comportamento de George e Yara em relação à disciplina de artes, notando que eles estavam mais interessados na realização das atividades e em participar da aula. A professora associou o período em que começou a notar essas mudanças a um tempo após o início deles no grupo terapêutico. A professora Carla também citou sobre a mudança de comportamento deles na realização das tarefas, pois pareciam estar mais comprometidos. As duas professoras também enfatizaram a transformação do comportamento de Yara em relação à fala e expressão corporal, pois estava mais calma e quieta.

Durante um Conselho de Classe, conforme relatado pela professora Carla, ela comentou para o grupo de professores sobre a mudança no comportamento de Yara, o que todos concordaram. Ela disse que acreditava que o grupo de $\mathrm{TO}$ e o trabalho da sala de recursos a auxiliaram nessa mudança, a partir de estímulos que favoreceram a expressividade de Carla, por exemplo, no contexto familiar, tendo em vista alguns conflitos que ela estava vivenciando nesse espaço. A professora concluiu que as questões familiares interferiam na aprendizagem da adolescente. Além das observações das profissionais, também durante alguns momentos da pesquisa foi possível identificar posicionamentos e comportamentos diferentes deles em relação às situações de aprendizagem. Entretanto, consoante nos aponta González Rey (2011b), as configurações subjetivas não são causas diretamente de um comportamento, mas são fontes de sentido subjetivo, que emergem durante o comportamento. Dessa forma, a complexidade que envolve a expressão de um comportamento, assim como a confluência de fatores que integram as dinâmicas subjetivas e as limitações metodológicas, como o tempo de acompanhamento, não nos permite afirmar sobre um movimento subjetivo e a emergência do sujeito nos três casos. No entanto, pode-se concluir sobre certas ações específicas, nas quais houve o início de posicionamentos dos adolescentes como sujeitos perante essas situações, destacando o papel das relações sociais e dos ambientes favorecedores nos processos de desenvolvimento subjetivo. 
De maneira específica, ressalta-se, conforme observado na pesquisa, a relevância do espaço da sala de recursos para o desenvolvimento dos alunos diagnosticados com TDAH, visto que, em termos de políticas públicas, o atendimento a esses alunos não está previsto nesse ambiente. Segundo a professora Carla, há outros atendimentos para esses alunos na rede educacional, porém eles são setoriais e não atuam diretamente na especificidade de cada contexto escolar. Ela destaca a importância da concretização de políticas públicas para serviços de apoio para os alunos diagnosticados com esse transtorno dentro do ambiente escolar. Em consonância com o discurso da profissional, o Projeto de Lei ${ }^{\circ}$ 7081/2010 chama atenção a fim de que se estabeleçam políticas públicas na educação básica que reconheçam que a população diagnosticada com TDAH e outros transtornos de aprendizagem precisa de apoio pedagógico no contexto da sala de aula. Diante desse contexto há, muitas vezes, questões burocráticas e institucionais que restringem o atendimento pedagógico integral a determinados alunos em situação de dificuldade de aprendizagem. Com isso, desvaloriza-se a existência de espaços e relações que possam favorecer e contribuir para o desenvolvimento desses alunos como sujeitos de seus processos de aprendizagem.

Apesar da relevância das relações sociais nesses processos de desenvolvimento subjetivo, nota-se que os principais recursos de mudanças nessas situações partiram dos próprios sujeitos, integrando a dinâmica subjetiva complexa, em momentos específicos. No caso dos três adolescentes, destaca-se, em relação aos recursos subjetivos produzidos, o papel das motivações e sua relação com a história de vida dos sujeitos. Segundo González Rey (2012), a motivação é um processo de produção de sentidos que se integra em uma configuração subjetiva, constituindo o espaço de sentido relacionado a determinada atividade concreta. Dessa maneira, compreendemos que a motivação se relaciona com a complexidade subjetiva de cada sujeito, a partir da trama simbólicoemocional que constitui a configuração única de sentido. Assim, há diversificados posicionamentos do sujeito em diferentes atividades, caracterizando a singularidade desse processo, compreendendo, conforme nos propõe o autor, que "a motivação não é específica de uma atividade, mas é uma motivação do sujeito [...]” (p. 127).

Assim, conforme nos aponta González Rey (2011b), o desenvolvimento não ocorre como expressão dos acontecimentos externos à pessoa, mas como "resultado de um sistema de relações que permite o engajamento da pessoa como sujeito e que 
reconhece possibilidades múltiplas de expressão nesse processo" (p.59). Dessa forma, verifica-se que o desenvolvimento pressupõe o aparecimento da condição de sujeito. A compreensão da condição de sujeito perante as dificuldades de aprendizagem surge com base em caminhos alternativos criados por cada um, a partir produção de novos sentidos subjetivos que possibilitam a reconfiguração subjetiva diante da aprendizagem, caracterizando a singularidade desse processo. Por consequência, as alternativas geradas no processo de aprender são momentos da processualidade da configuração subjetiva na aprendizagem (González Rey, 2011b).

Essas reflexões apontam, portanto, para a necessidade de intervenções no contexto das dificuldades de aprendizagem que produzam a emergência do sujeito. A partir da compreensão da singularidade, favorecida pela análise das configurações subjetivas em detrimento de técnicas padronizadas.

\subsection{Articulações entre a Teoria da Subjetividade e a Terapia Ocupacional}

Os casos e contextos analisados nos possibilitaram identificar reflexões sobre possíveis contribuições da Teoria da Subjetividade para a prática da Terapia Ocupacional, a partir da compreensão da singularidade do aluno com dificuldade de aprendizagem, que é objetivo desse estudo. Desse modo, destacam-se alguns tópicos de análise sobre os quais nos aprofundaremos, são eles: a estratégia terapêutica do grupo, o desenvolvimento subjetivo e a emergência do sujeito, e a dupla função das atividades em Terapia

\section{Ocupacional.}

Há evidências de poucos registros teóricos e práticos sobre a atuação da Terapia Ocupacional com crianças/adolescentes com dificuldades de aprendizagem. A maioria dos trabalhos que abrangem as ações da profissão no contexto educacional, o que também não são muitos, retrata a atuação com crianças/adolescentes com dificuldades físicas, motoras ou sensoriais, dentre eles: Ide, Yamamoto e Silva (2011), Jurdi, Brunello e Honda (2004), Jurdi e Amiralian (2006), entre outros. E assim, as estratégias terapêuticas têm ênfase em aspectos como: adequações físicas e no mobiliário, adaptação de materiais escolares, atendimentos individuais e com a família e, em menor destaque, a formação de alguns grupos de reflexão e esclarecimento com pais e professores sobre as deficiências. 
Os poucos registros em relação às práticas da $\mathrm{TO}$ no atendimento de alunos com dificuldades de aprendizagem, no caso, com TDAH, estão voltados para atendimentos individuais. Eles têm como principais objetivos o desenvolvimento de componentes de desempenho que são prejudicados em decorrência das características do transtorno e que interferem na realização das atividades do cotidiano.

Então, nesse contexto de atuação, percebe-se que é dada pouca ênfase para aspectos relacionais, a partir da valorização de espaços de discussão e reflexão como estratégias terapêuticas que promovam o desenvolvimento do sujeito. Sendo assim, o grupo terapêutico em TO, analisado na pesquisa como uma estratégia coletiva de atendimento em detrimento do individual, pode representar o início de um avanço da atuação da profissão frente às dificuldades de aprendizagem, a partir da valorização das produções subjetivas. Essa estratégia terapêutica permitiu um enfraquecimento da centralidade do terapeuta como uma voz única e hegemônica possuidora de verdades e técnicas "prontas", possibilitando a criação de um espaço coletivo de intercâmbio de experiências e vivências, estimulando reflexões que podem favorecer a emergência do sujeito capaz.

Apesar de a estratégia grupal possibilitar um espaço coletivo, que estimula a emergência do sujeito, é necessário que ocorram mudanças em determinadas condutas terapêuticas. No grupo analisado, apesar de favorecer espaços que deram "voz aos sujeitos", o foco de atuação da TO ainda estava em aspectos externos a eles, ou seja, principalmente no desenvolvimento de componentes orgânicos e biológicos relacionados ao transtorno. Porém, a análise do grupo realizada neste estudo, juntamente com a compreensão da dinâmica subjetiva dos adolescentes e das relações no contexto escolar unido ao referencial teórico, possibilita-nos refletir sobre possíveis estratégias para o processo terapêutico ocupacional com alunos com dificuldades de aprendizagem.

As contribuições práticas da pesquisa aliadas ao referencial teórico da Subjetividade, sob o marco histórico-cultural, permitiu-nos compreender que, no processo terapêutico, os principais recursos para o enfrentamento das dificuldades de aprendizagem não estão em procedimentos ou instrumentos, mas nos próprios sujeitos. Logo, torna-se necessário que o foco terapêutico não recaia sobre estratégias universais e externas ao individuo, mas na compreensão da emergência do sujeito nesse processo, a partir da valorização do desenvolvimento subjetivo no espaço terapêutico. 
González Rey (2007a, 2011b) nos propõe novas possibilidades de atuação na clínica, mais especificamente no campo da Psicoterapia, com base na Teoria da Subjetividade. Por compreendermos as implicações dessas questões também em outros contextos do campo da saúde, articulamos essas considerações com o campo da Terapia Ocupacional. É importante destacar que, para o autor, as implicações da teoria na prática não devem ser utilizadas como um modelo teórico rígido, mas como forma de compreensão da processualidade de sistemas subjetivos complexos, a partir da análise de configurações subjetivas singulares. Assim, nessa compreensão, no processo terapêutico as mudanças não acontecem diretamente por intervenção do terapeuta. A ação se torna bem sucedida quando possibilita o início de um processo de subjetivação, que implica a produção de novos sentidos subjetivos, representando um processo alternativo frente às configurações subjetivas diante dos conflitos (2007a).

Além disso, compreende-se que a opção de saúde mais favorável é aquela que tenha como foco a capacidade geradora dos sujeitos, pois as atividades e relações sempre encontram formas de subjetivação que as perpetuam (2011b). Desse modo, compreendese a importância de o processo terapêutico estar organizado de modo a criar estratégias que estimulem o desenvolvimento subjetivo, possibilitando que o "paciente" se torne um sujeito ativo perante os enfrentamentos das suas dificuldades, sejam elas de aprendizagem ou de qualquer outro aspecto referente à Terapia Ocupacional.

Essas estratégias consistem na construção de um ambiente terapêutico que possibilite que o sujeito se expresse e seja capaz de refletir, e assim, construir caminhos alternativos diante das suas dificuldades, a partir da produção de novos sentidos subjetivos. A esses espaços, González Rey (2007a) denomina de espaços de sentido subjetivo, que são responsáveis por propiciarem a emergência de novos sentidos subjetivos a partir de novos focos de relação. A construção desse espaço ocorre primeiramente na esfera relacional, onde a partir de atitudes e ações de disponibilidade, escuta e acolhimento por parte do profissional, o paciente possa se sentir confiante para se expressar, gerar alternativas e assumir um posicionamento de sujeito, considerando-se as configurações subjetivas com base na produção de novos sentidos subjetivos.

No grupo terapêutico analisado durante a pesquisa, verifica-se que a flexibilização do processo terapêutico e as atitudes da terapeuta, a partir da escuta e acolhimento, foram elementos que favoreceram a criação de espaços de comunicação e expressão dos 
adolescentes. Porém, nesses espaços as questões não eram aprofundadas, com intuito de gerar reflexões nos participantes e possibilitar processos de mudança. A pessoa só emerge como sujeito dentro de um processo dialógico quando ele aparece em uma reflexividade autêntica, espontânea e a ativa (González Rey, 2007a). Dessa forma, percebeu-se que a profissional valorizava a importância de dar voz ao sujeito na terapia, porém não compreendia essa estratégia como um recurso de mudança dentro do processo terapêutico. Assim, ela concebia a possibilidade de "sucesso terapêutico" com base em recursos externos aos indivíduos, como por exemplo, nas atividades terapêuticas, a partir do desenvolvimento de componentes que devam ser treinados, e em outras competências profissionais. Então, a partir das reflexões anteriores, compreende-se que ser sujeito é uma produção singular a partir da complexidade da dinâmica subjetiva, não podendo ser determinado por algo externo à pessoa, seja um procedimento ou ação terapêutica, caracterizando o que o autor denomina de ética do sujeito (2011b).

A valorização do desenvolvimento subjetivo, com base na emergência do sujeito no processo terapêutico, implica compreender a dinâmica subjetiva desses "pacientes". Portanto, consiste em buscar estratégias para compreender quem eles são e como esses processos se organizam, a partir da investigação das configurações subjetivas, que permitem a construção de hipóteses sobre a complexidade da dinâmica subjetiva das pessoas atendidas, no nosso caso, os adolescentes. Para essa compreensão, é necessário criar possibilidades para que o outro se expresse, e perceba quem ele é naquele momento, sendo o diálogo o principal instrumento (González Rey, 2007a). Assim, ressalta-se outra questão apontada pelo autor: a conduta do terapeuta, na qual ele também se torna sujeito, a partir do caráter construtivo-interpretativo do processo. Por conseguinte, a atuação do terapeuta não é limitada e enrijecida por aportes teóricos ou metodológicos, mas ele mesmo é capaz de conduzir esse processo, com base nas singularidades.

Para a prática da Terapia Ocupacional, além do diálogo como recurso para a emergência do sujeito, pode-se dar maior ênfase para as atividades, pois, conforme já contextualizado neste trabalho, elas adquirem um papel de destaque nos princípios da profissão. Dessa maneira, elas possuem dupla função no processo em TO: as atividades como um instrumento terapêutico e as atividades humanas, ou ocupações, que constituem o cotidiano e são a finalidade da intervenção no processo. Pautados nisso, buscou-se apresentar uma perspectiva teórico-metodológico dessa dupla função das atividades para 
a prática da Terapia Ocupacional, tendo como norteadores os princípios da Teoria da Subjetividade. Isso porque o autor (2007a) também enfatiza o papel das atividades não dialógicas como forma de favorecer a produção de novos processos de subjetivação que transformem a configuração subjetiva diante do sofrimento atual, relacionando com aspectos do modo de vida. Primeiramente, aborda-se as atividades como instrumentos terapêuticos para a construção de hipóteses, e logo após, as atividades humanas como possibilidades de desenvolvimento subjetivo, a partir da articulação com o conceito de modo de vida.

A análise do grupo terapêutico possibilitou-nos a compreensão de que as atividades terapêuticas, como os jogos e dinâmicas que foram utilizados, representaram instrumentos impulsionadores para o surgimento de questões subjetivas, estando eles além de suas funções objetivas planejadas. A atividade da história, por exemplo, como relatado, favoreceu a expressão de aspectos contextuais e da história de vida desses sujeitos, mesmo que não fossem valorizadas e exploradas pela profissional, como um recurso para estimular processos de diálogo e reflexão. Desse modo, González Rey (2011b) destaca que a diversidade de atividades é um importante recurso de mudança dos aspectos subjetivos, sensório-motores e cognitivos implicados nessas atividades, que contribui para novos espaços de produção subjetiva. Assim, a diversidade de atividades propostas no processo terapêutico em TO pode estimular diversas questões, sejam elas objetivas ou subjetivas, com destaque para os espaços de produção subjetiva. Dessa maneira, além da utilização das atividades a fim de atingir os objetivos já "tradicionais" da Terapia Ocupacional, elas podem ir além e desenvolver questões que estão implicadas no desenvolvimento da subjetividade.

González Rey (2007a) propõe a utilização de instrumentos no processo terapêutico, a fim de provocar formas diferenciadas de expressão do sujeito, que se configuram como fontes importantes para o desenvolvimento de hipóteses. Para o autor, as hipóteses se constituem como ferramentas nesse processo construtivo-interpretativo, que orientam o posicionamento do terapeuta, por exemplo, a fim de favorecer o desenvolvimento humano. Assim, elas constituem base para o planejamento terapêutico, no sentido de contribuir para a elaboração de estratégias terapêuticas, incluindo o diálogo e outras atividades que permitam ao sujeito construir caminhos alternativos de desenvolvimento. 
Assim sendo, é possível constatar que os instrumentos terapêuticos foram utilizados pela Terapeuta Thaís com o objetivo de favorecer momentos de expressão e comunicação, porém não foram desenvolvidos no sentido de formular hipóteses, a partir da construção de indicadores, provocando momentos de reflexão e questionamento profissional diante do paciente. González Rey (2007a) destaca que o processo terapêutico não deve ser orientado somente para a conversa, mas também para um espaço dialógico, onde o terapeuta adota diferentes formas de atuação, baseadas tanto nas questões originárias do diálogo, como também nas hipóteses construídas, que se tornam ferramentas nesse processo. Logo, as ações da terapeuta, apesar de favorecerem a expressão e comunicação, estavam mais centradas em uma conversado que na construção de um diálogo. Destaca-se, dessa forma, a importância da utilização dos instrumentos terapêuticos a fim de identificar configurações subjetivas, possibilitando a construção de hipóteses e de um modelo teórico que estão envolvidos no problema, para favorecer um desenvolvimento subjetivo.

Castro, Lima e Brunello (2001) citaram as atividades em TO como estratégias terapêuticas para a construção de novos caminhos, "[...] a partir da realização de atividades é possível completar experiências que ficaram destituídas de sentido e significado ou criar novos sentidos e significados para as experiências vividas [...]”. Dessa forma, na prática da Terapia Ocupacional, com base nas implicações da Teoria da Subjetividade, é possível reposicionar esse pensamento das autoras, compreendendo as atividades como forma de estímulo à produção de novos sentidos subjetivos com base em reconfigurações subjetivas. Dessa maneira, as atividades surgem como possibilidade de intrigar, provocar, levar à reflexão, que, aliadas ao diálogo, permitem um desenvolvimento subjetivo.

Além das atividades como instrumentos terapêuticos, na Terapia Ocupacional, o foco de atuação da profissão está nas ocupações, que são as atividades implicadas de sentidos e significados constitutivas do cotidiano das pessoas, conforme relatado nos capítulos iniciais deste trabalho. A partir da compreensão das ocupações como elementos importantes que integram a dinâmica subjetiva singular de cada pessoa, propomos possibilidades de intervenção da profissão, diante das implicações da Teoria da Subjetividade, com base no conceito de modo de vida, enfatizado por Gonzaléz Rey (2007a, 2011b). 
O autor defende que a visão mecanicista na saúde de que o organismo funciona como uma "máquina" e, se tem problemas, significa que houve defeito nessa aparelhagem. Essa visão mecanicista desconsidera aspectos relacionados ao modo de vida das pessoas. Porém, trabalhar essa questão, juntamente com aspectos da qualidade de vida torna-se essencial como ação terapêutica (2007a). O modo de vida se relaciona com " $a$ organização do tempo, formas de alimentação, os tipos de atividade que as pessoas se envolvem na vida cotidiana, e como esse envolvimento acontece [...]” (GONZÁLEZ REY, 2011, p. 30). Assim, compreende-se que o modo de vida engloba as ocupações humanas, e o desenvolvimento dessas questões na prática terapêutica da TO torna-se relevante, com base nas implicações teórico-práticas da Teoria da Subjetividade.

Conforme destaca o autor (2011b, p.195), "o sistema de atividades humanas se configura em um sistema de organização subjetiva”. A descrição da rotina dos três adolescentes permitiu-nos observar que as atividades realizadas no cotidiano de cada um expressavam aspectos da dinâmica subjetiva dos três. Além disso, elas representavam possibilidades de intervenções e proposições de alternativas, com implicações na produção de novos sentidos subjetivos a partir da organização do cotidiano.

Dessa forma, é possível concluir que estratégias terapêuticas focadas nas intervenções nessas atividades e na organização da rotina e do cotidiano podem facilitar processos de práticas que se configuram subjetivamente. Nos trabalhos de Bezerra e González Rey (2014) e Batista e Tacca (2011), os autores propõem a relação entre a falta de vivência de situações do cotidiano com a aprendizagem. Eles destacam as intervenções com ênfase em atividades do cotidiano como possibilidades de desenvolvimento no contexto de aprendizagem. Goulart e González Rey (2013) também retratam, a partir de pesquisa realizada pelos autores, as atividades relacionadas ao modo de vida se constituírem como recursos para o desenvolvimento subjetivo perante configuração subjetiva do transtorno, a partir da contribuição delas na ampliação das relações sociais, do cuidado cotidiano e no relacionamento com os outros.

Assim, o autor observa que as ações relacionadas ao modo de vida representam possibilidades educativas, a partir elaboração de novas maneiras de produção subjetiva, que geram implicações no desenvolvimento. 
Conforme apontamentos desses estudos, também se verifica que os três casos analisados nesse trabalho permitem possibilidades de intervenções com foco nos aspectos do modo de vida. Por exemplo, no caso da Alice, a preferência por atividades manuais e de expressão pode ser utilizada como recursos interventivos que favoreçam um desenvolvimento subjetivo, tanto como instrumentos terapêuticos, como intervenção no modo de vida. Além disso, o cotidiano de Yara indicava a ausência e limitação de atividades, sendo indicado por ela o desejo de realizar atividades físicas. Dessa forma, a organização dessas atividades no cotidiano de Alice pode estimular, a partir da produção de novos sentidos subjetivos, a reconfiguração subjetiva do transtorno, considerando a emergência do sujeito. Assim também, o diário reflexivo, proposto por González Rey (2007a), também representaria uma possibilidade de intervenção com Alice, conforme já utilizado por ela em estratégia semelhante. Esse recurso representaria a possibilidade de contribuir no controle de suas emoções, podendo estimular processos de mudanças subjetivas.

As estratégias de intervenção com base em atividades e rotinas do modo de vida, conforme propõe González Rey (2011b), podem representar novas possibilidades de desenvolvimento de processos subjetivos. Consideramos que a inclusão de novas atividades, unida à alteração de rotinas e tipos de comportamentos que estavam associados a configurações subjetivas diante do conflito, possibilita a produção de novos sentidos subjetivos, favorecendo um desenvolvimento pessoal.

Dessa maneira, destaca-se neste trabalho as possibilidades de avanços no campo teórico-prático em TO, com base no fundamento da profissão: as atividades, compreendendo-as como possibilidades favorecedoras de processos de desenvolvimento subjetivo, com foco na emergência do sujeito. Desse modo enfatiza-se a necessidade de modificações nas bases teórico-práticas da profissão, para contribuir com o processo de enfrentamento das dificuldades de aprendizagem, a partir da compreensão da complexidade subjetiva que envolve os processos humanos, conforme contribuições da Teoria da Subjetividade. 


\section{7-CONSIDERAÇÕES FINAIS}

A pesquisa nos possibilitou a reflexão sobre possíveis implicações da Teoria da Subjetividade para a prática da Terapia Ocupacional, tendo em vista os aspectos subjetivos dos sujeitos que enfrentam situações de dificuldades de aprendizagem, conforme objetivo inicial deste trabalho. $\mathrm{O}$ desenvolvimento deste estudo representou desafios significativos no campo epistemológico e metodológico, principalmente a partir da compreensão da inovação na articulação entre essas áreas, por serem campos teóricos e práticos ainda não explorados. Além disso, no campo empírico da Terapia Ocupacional, por existirem poucas intervenções relacionadas ao contexto educacional, encontramos uma barreira para localizar um campo prático, tendo em vista a realização da pesquisa.

A compreensão da singularidade do sujeito foi possível a partir do referencial da Teoria da Subjetividade de González Rey, que nos permitiu avanços no campo metodológico e teórico. Nos aspectos metodológicos, percebemos o valor heurístico das categorias de sentido subjetivo e configuração subjetiva para a compreensão da organização subjetiva dos adolescentes. Além disso, as contribuições epistemológicas da Teoria, conforme observada na pesquisa, possibilitou-nos questionar o valor heurístico do diagnóstico de TDAH, a partir da compreensão da complexidade que envolve os comportamentos e o processo de aprendizagem. Dessa forma, destaca-se a necessidade de compreensão do diagnóstico, com base na análise das configurações subjetivas, estando além de sintomas e comportamentos, mas em como eles se organizam na história de vida de cada sujeito.

Partindo-se desses pressupostos, tornou-se possível compreender as dificuldades de aprendizagem como um sistema complexo e dinâmico, que vai além dos comportamentos evidentes, com implicações significativas das relações sociais nesse processo. Além disso, o estudo propiciou compreender a importância dos aspectos relacionais para o desenvolvimento dos sujeitos, considerando a constituição de espaços sociais que favoreciam processos de comunicação e expressão. Dessa maneira, pôde-se ampliar as reflexões sobre o processo terapêutico no contexto das dificuldades de aprendizagem.

As implicações da teoria representaram contribuições significativas, em relação aos aspectos teóricos, para a construção de possibilidades de avanços no campo 
profissional de Terapia Ocupacional. A partir da concepção da aprendizagem como produção subjetiva singular e das práticas em saúde com base no desenvolvimento subjetivo, identificamos a emergência do sujeito. Desse modo, destaca-se a necessidade de mudanças na concepção das dificuldades de aprendizagem, a partir da compreensão dos aspectos subjetivos dos sujeitos, a fim de que ocorram transformações nas ações em saúde nesse processo. Em relação à prática da Terapia Ocupacional, assim como em outros contextos, as principais contribuições a partir das implicações da Teoria da Subjetividade estão relacionadas ao favorecimento de estratégias que estimulem processos de desenvolvimento subjetivo, focados na emergência do sujeito. Dessa maneira, temos a compreensão que os principais recursos de mudança estão nos próprios sujeitos, a partir da singularidade de sua constituição subjetiva, conforme observou-se nos casos analisados.

Nesse sentido, uma possibilidade de avanço mais específico de acordo com as competências profissionais da TO está nas atividades terapêuticas, não só como instrumentos como também na finalidade terapêutica. Portanto, há a possibilidade de as atividades se constituírem como recursos terapêuticos que possibilitem ao terapeuta o conhecimento da singularidade do sujeito, a partir da construção de hipóteses e como recursos que estimulem produções subjetivas nos participantes. As implicações das atividades como finalidade do processo terapêutico estão em favorecer processos de desenvolvimento, cujas intervenções tenham como foco aspectos do modo de vida, incluindo as ocupações e rotina. Além disso, destaca-se a relevância da concretização de ambientes terapêuticos e/ou educativos que priorizem, a partir da relação com o outro, espaços dialógicos e expressivos dos sujeitos, compreendendo a importância deles para processos de reflexões e produções subjetivas, conforme observado na pesquisa.

O percurso dessa pesquisa possibilitou grandes contribuições para além do papel de pesquisadora, mas para a formação profissional como terapeuta ocupacional. Dessa forma, o desafio de realizar articulações entre as implicações da Teoria da Subjetividade e a atuação profissional da Terapia Ocupacional no espaço escolar, a partir da compreensão de aspectos subjetivos dos adolescentes nesse contexto, possibilitou-me a reflexão e ampliação de concepções sobre o processo terapêutico. Os avanços e considerações significativas apresentadas nessa pesquisa, observadas no campo empírico 
e articuladas com o referencial teórico, representam novos elementos que integram o meu campo profissional, permitindo um reposicionamento na atuação como terapeuta.

A principal contribuição da pesquisa está na relevância deste trabalho para a articulação entre a área da saúde-educação, mais especificamente para a profissão de Terapia Ocupacional. O campo teórico-prático da atuação da TO no contexto de dificuldades de aprendizagem ainda é escasso. Porém, dada a importância que o tema vem adquirindo no ambiente escolar, principalmente em relação ao diagnóstico de TDAH, torna-se necessário maiores intervenções baseadas nas implicações retratadas nesta pesquisa.

Assim, destaca-se o campo profissional da Terapia Ocupacional, compreendendo suas possibilidades de contribuição nesse contextocom base nos princípios da Teoria da Subjetividade. Então, é imperioso frisar a relevância dessa pesquisa para maiores aprofundamentos e exploração no campo empírico e teórico, com vistas a enriquecer a formação do terapeuta ocupacional e ampliar as possibilidades de atuação da profissão em diversos campos, além do contexto educacional, proporcionando contribuições principalmente para a população atendida pelo serviço de Terapia Ocupacional. 


\section{8-REFERÊNCIAS}

ABDA. O que é o TDAH. Disponível em: http://www.tdah.org.br/sobre-tdah/o-que-e-otdah.html. Acesso em 22/03/2017.

ANTUNES, C. Inclusão: o nascer de uma nova pedagogia. São Paulo, Ciranda cultural, 2008.

AOTA. Carleto et al(trad.) Estrutura da prática da terapia ocupacional: domínio e processo - 2. ${ }^{\text {a }}$ edição. Rev. Triang. : Ens. Pesq. Ext. Uberaba-MG, v. 3. $n$. 2, p. 57-147, jul/dez. 2010

BATISTA, A; TACCA, M. “Cada ser, em si, carrega o dom de ser capaz, de ser feliz": um estudo de caso baseado em Alfred Adler, Lev Vigotski e González Rey. Dissertação (Mestrado em Educação) - Faculdade de Educação, Universidade de Brasília. Brasília, 2011.

BEZERRA, M; GONZÁLEZ REY, F. Dificuldade de aprendizagem e subjetividade: para além das representações hegemônicas do aprender. Dissertação (Mestrado em Educação) - Faculdade de Educação, Universidade de Brasília. Brasília, 2014.

Biografia de Adolf Meyer. Disponível em: http://www.biografiasyvidas.com/biografia/m/meyer_adolf.htm. Acesso em 09/12/2015. BRASIL. Ministério da Educação. Portaria Ministerial no 13 de 24 de Abril de 2017. Dispõe sobre a criação do "Programa de Implantação de Salas de Recursos Multifuncionais". Disponível em:

http://portal.mec.gov.br/index.php?option=com_docman\&view=download\&alias=9935portaria-13-24-abril-2007\&Itemid=30192. Acesso em 22/03/2017.

Resolução CNE/CEB $\mathbf{n}^{\circ}$ 4, de 02 de Outubro de 2009. Institui Diretrizes operacionais para o atendimento Educacional Especializado na Educação Básica, modalidade Educação Inclusiva. Disponível em: http://portal.mec.gov.br/dmdocuments/rceb004_09.pdf. Acesso em 22/03/2017.

Projeto de Lei 7081/2010. Dispõe sobre o diagnóstico e o tratamento da dislexia e do Transtorno do Deficit de Atenção com Hiperatividade na educação básica. Disponível em: http://www.camara.gov.br/proposicoesWeb/fichadetramitacao?idProposicao=472404. Acesso em 22/03/2017. 
CASTRO, E. D; LIMA, E. M. F; BRUNELLO, M. I. B. Atividades humanas e Terapia Ocupacional. In DE CARLO, M. M. R., BARTALOTTI, C. C(orgs.). Terapia Ocupacional no Brasil: fundamentos e perspectivas. São Paulo, Plexus Editora, 2001. p. 41-59.

COSTABILE, C; BRUNELlO, M. I. B. Repercussões da inclusão escolar sobre o cotidiano de crianças com deficiência: um estudo a partir do relato das famílias. Rev. Ter. Ocup. Univ. São Paulo, v. 16, n. 3, p. 124-130, set. /dez., 2005.

CREFITO. Definição de Terapia Ocupacional. Disponível em: http://crefito11. org. br/terapia-ocupacional/. Acesso em 11/09/2015.

DE CARLO, M. M. R; BARTALOTTI, C. C. Caminhos da Terapia Ocupacional In DE CARlO, M. M. R., BARTALOTTI, C. C(orgs). Terapia Ocupacional no Brasil: fundamentos e perspectivas. São Paulo, Plexus Editora, 2001. p. 19-39.

DE PAULA, A. F. M; BALEOTTI, L. R. Inclusão escolar do aluno com deficiência física: contribuições da Terapia Ocupacional. Cadernos de Terapia Ocupacional da UFSCar, São Carlos, Jan/Abr 2011, v. 19, n. 1, p. 53-69.

FRANCISCO, B. R. Terapia Ocupacional. Campinas. São Paulo, Papirus, 2001. $2^{\circ}$ ed. rev.

GALHEIGO, S. M. O cotidiano na terapia ocupacional: cultura, subjetividade e contexto histórico social. Rev. Ter. Ocup. Univ. São Paulo, v. 14, n. 3, p. 104-9, set. /dez. 2003.

GONZÁLEZ REY, F. Pesquisa qualitativa em Psicologia: caminhos e desafios. São Paulo, Thompson, 2002.

O valor heurístico da subjetividade na investigação psicológica. In: González Rey, F. L. (org.). Subjetividade, Complexidade e Pesquisa em Psicologia. São Paulo: Pioneira Thompson Learning, 2005a, p. 27-51.

Pesquisa qualitativa e subjetividade: o processo de construção da informação. São Paulo, Thompson, 2005b.

Psicoterapia, subjetividade e pós-modernidade: uma aproximação histórico-cultural. São Paulo, Thompson Learning, 2007a.

As categorias de sentido, sentido pessoal e sentido subjetivo: sua evolução e diferenciação na teoria histórico-cultural. Psic. da Ed., São Paulo, 24, $1^{\circ}$ sem. de 2007b, p. $155-179$. 
Os aspectos subjetivos no desenvolvimento de crianças com Necessidades Especiais: além dos limites concretos do defeito. In: MARTíNEZ, A. M; TACCA, M. C. Possibilidades de aprendizagem: ações pedagógicas para alunos com dificuldades e deficiências. Campinas, Alínea, 2011a(p. 47-68).

Subjetividade e saúde: superando a clínica patológica. São Paulo, Cortez: $2011 b$.

O social na psicologia e a psicologia social: a emergência do sujeito. 3 ed. Petrópolis, RJ: Vozes, 2012.

A imaginação como produção subjetiva: as ideias e os modelos da produção intelectual. In: MARTÍNEZ, A.M; ÁLVAREZ, P. O sujeito que aprende: diálogo entre a psicanálise e o enfoque histórico-cultural. Brasília, Liber livro, 2014(p.35-61).

GOULART, D; GONZALEZ REY, F. Institucionalização, subjetividade e desenvolvimento humano: abrindo caminhos entre educação e saúde mental. Dissertação (Mestrado em Educação) - Faculdade de Educação, Universidade de Brasília. Brasília, 2013.

IDE, M. G. YAMAMOTO, B. T; SILVA, C. C. Identificando possibilidades de ação da Terapia Ocupacional no processo de inclusão. Cad. Ter. Ocup. UFSCar, São Carlos, v. 19, n. 3, p. 323-332, 2011.

JURDI, A. P. S.; BRUNELLO, M. I. B.; HONDA, M. Terapia ocupacional e propostas de intervenção na rede pública de ensino. Rev. Ter. Ocup. Univ. São Paulo, v. 15, n. 1. p. 26-32, jan. /abr. 2004.

JURDI, A. P. S; AMIRALIAN, M. L. T. M. A inclusão escolar de alunos com deficiência mental: uma proposta de intervenção do terapeuta ocupacional no cotidiano escolar. Estudos de Psicologia, Campinas23(2), 191-202, 2006.

LOURENÇO, G. F; CID. F. B. Possibilidades de ação do Terapeuta Ocupacional na educação infantil: congruência com a proposta da educação inclusiva. Cadernos de Terapia Ocupacional da UFSCar, São Carlos, Mai/Ago 2010, v. 18, n. 2, p. 169-179.

MADEIRA-COELHO, C. A categoria de sentido subjetivo: valor teórico e evidências empíricas. In: MARTÍNEZ, A. M; ÁLVAREZ, P. (orgs). O sujeito que aprende: diálogo entre psicanálise e o enfoque histórico-cultural. Brasília, Liber Livro, 2014(p. 99-122). 
MARCELINO, J. F. A diferença no cenário familiar, a inclusão escolar e a Terapia Ocupacional. Cad. Ter. Ocup. UFSCar, São Carlos, v. 21, n. 1, p. 187-193, 2013.

MITJANS MARTÍNEZ, A. A teoria da subjetividade de González Rey: uma expressão do paradigma da complexidade na psicologia. In: GONZÁlEZ REY, F. L. Subjetividade, complexidade e pesquisa em Psicologia. São Paulo: Pioneira Thompson Learning, 2005.

MITJANS, MARTÍNEZ A.; TACCA. M. C. V. R. Possibilidades de aprendizagem: ações pedagógicas para alunos com dificuldades e deficiência. Campinas, SP: Ed. Alínea, 2011. MOYSES. M.A.A. A institucionalização invisível: crianças que não aprendem na escola. Campinas, SP: Mercado de Letras, Fapesp, 2001.

MUNGUBA, M. C. Inclusão escolar. In CAVALCANTI, A; GALVÃO, C. Terapia Ocupacional: fundamentação e prática. Rio de Janeiro: Guanabara Koogan, 2007. p. $519-525$.

NASCIMENTO, B. A. O mito da atividade terapêutica. Revista de Terapia Ocupacional-USP, São Paulo, 1990.

PELOSI, M. B. O papel do terapeuta ocupacional na tecnologia assistiva. Cadernos de Terapia Ocupacional da UFSCar, 2005, vol. 13, nº 1 .

RAAD, I. L. F; TUNES, E. Deficiência como iatrogênese. . In: MARTÍNEZ, A. M; TACCA, M. C. Possibilidades de aprendizagem: ações pedagógicas para alunos com dificuldades e deficiências. Campinas, Alínea, 2011(p. 15-45).

ROCHA, E. F. A Terapia Ocupacional e as ações na educação: aprofundando interfaces. Rev. Ter. Ocup. Univ. São Paulo, v. 18, n. 3, p. 122-127, set. /dez. 2007.

ROCHA, E. F; LUIZ, A.; ZULIAN, M. A. R; Reflexões sobre as possíveis contribuições da terapia ocupacional nos processos de inclusão escolar. Rev. Ter. Ocup. Univ. São Paulo, v. 14, n. 2, p. 72-8, maio/ago. 2003.

ROSSATO, M; MITJÁNS MARTÍNEZ, A. O movimento da subjetividade no processo de superação das dificuldades de aprendizagem escolar. Tese (Doutorado em Educação) Faculdade de Educação, Universidade de Brasília. Brasília, 2009.

SÁ, M. C. A fraternidade em questão: um olhar psicossociológico sobre o cuidado e a "humanização" das práticas de saúde. Interface (Botucatu), Botucatu, v. 13, supl. 1, p. 651-664, 2009.

TACCA, M.C. Além de professor e aluno: a alteridade nos processos de aprendizagem e desenvolvimento. In: In: SIMÃO, L. M.; MITJÁNS MARTíNEZ, A. (Org.). O outro no 
desenvolvimento humano: diálogos para a pesquisa e a prática profissional em Psicologia. São Paulo: Thomson, 2004, p.101-130.

GONZALEZ, F. L. Produção de sentido subjetivo: as singularidades dos alunos no processo de aprender. Psicologia ciência e profissão, 2008, 28(1), 138-161. TOYODA, C. Y; MENDES, E. G; LOUREÇO, G. F; AKASHI, L. T. O contexto multidisciplinar da prática da Terapia Ocupacional frente ao paradigma da inclusão escolar. Cadernos de Terapia Ocupacional da UFSCar, São Carlos, jul-dez 2007, v. 15, n. 2, $p$ 121-130.

TREVISAN, J. G. DELLA BARBA, P. C. S. Reflexões acerca da atuação do terapeuta ocupacional no processo de inclusão escolar de crianças com necessidades educacionais especiais. Cad. Ter. Ocup. UFSCar, São Carlos, v. 20, n. 1, p. 89-94, 2012. TROMBLY, C. A. Ocupação. In TROMBLY, C. A; RADOMSKI, M. V. Terapia Ocupacional para disfunções físicas. 5. ed. São Paulo: Santos Editora. p. 255-281. VYGOTSKY, L. S. Pensamento e Linguagem. São Paulo: Martins Fontes, 1989. Obras escogidas. V. V - Fundamentos da Defectologia. Madrid: Visor. 1997. 


\section{APÊNDICÊS \\ APÊNDICE A-COMPLEMENTO DE FRASE}

1) Eu queria...

2) Minha escola...

3) Fico triste...

4) Minha família...

5) Meu maior sonho...

6) É difícil...

7) A sala de recursos é...

8) Se pudesse mudar algo, mudaria...

9) Fico feliz...

10) Estudar...

11) É fácil...

12)Odeio...

13) Quando não consigo aprender, eu me sinto...

14) Meus amigos são...

15) Meu maior problema...

16) No grupo da Terapia Ocupacional...

17) Meus professores...

18) Fico com raiva...

19) Amo...

20) A escola perfeita seria... 
APÊNDICE B-AS TRÊS COISAS
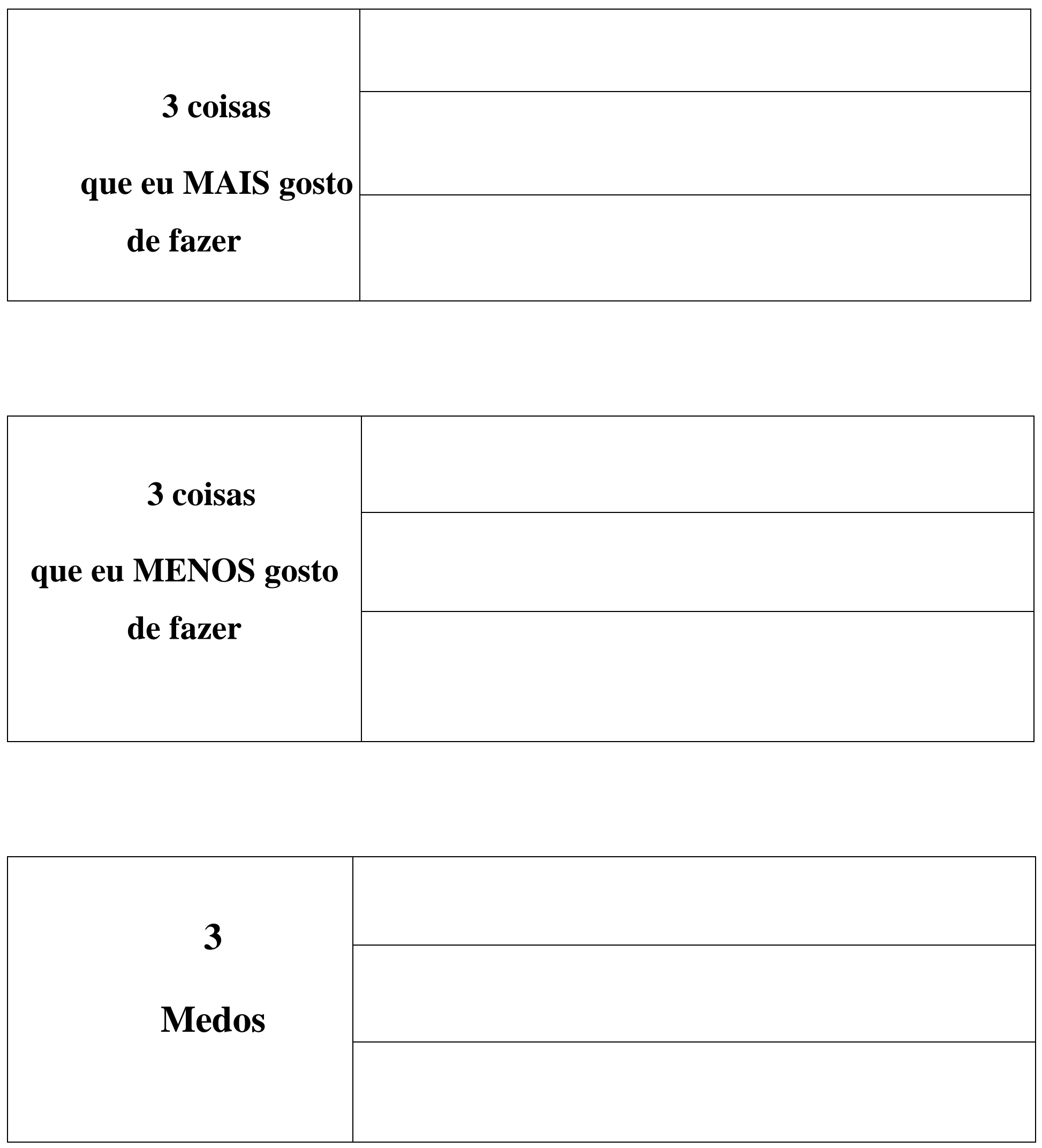
3 coisas

que eu mudaria

na minha escola.

3 pessoas

importantes para mim

\begin{tabular}{|c|c|}
\hline \multirow{2}{*}{3} & \\
\cline { 2 - 2 } Palavras que & \\
\cline { 2 - 2 } descrevem quem eu & \\
\cline { 2 - 2 } & \\
\hline
\end{tabular}


150

APÊNDICE C-DESENHO “O MUNDO IDEAL”- GEORGE

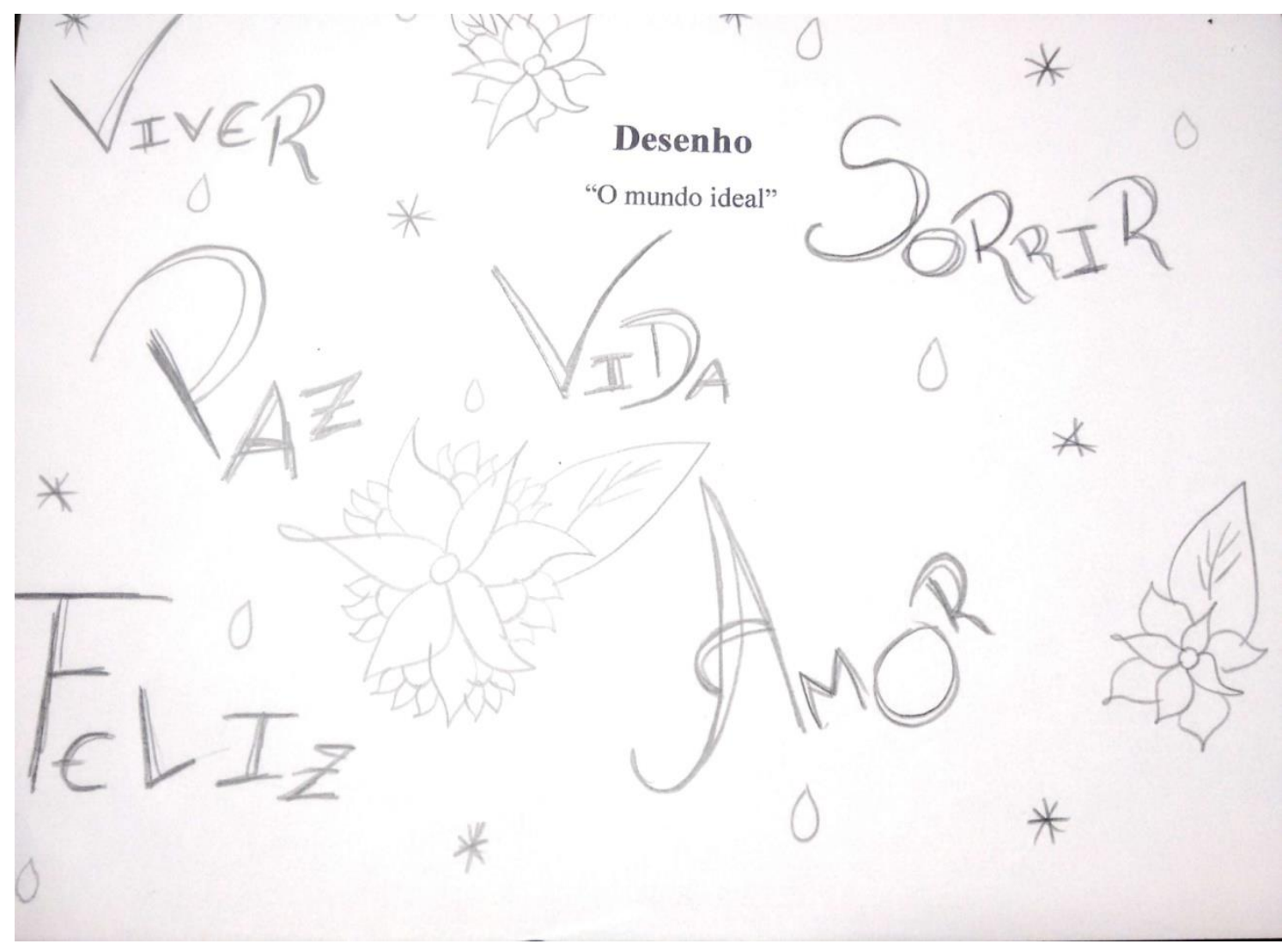


APÊNDICE D-DESENHO “O MUNDO IDEAL”-ALICE

\section{Desenho}

"O mundo ideal" 


\section{APÊNDICE E- TERMO DE CONSENTIMENTO LIVRE ESCLARECIDO(TCLE)}

Este é um convite especial para seu filho(a) participar voluntariamente da pesquisa "AS INTERFACES ENTRE A TERAPIA OCUPACIONAL E A TEORIA DA SUBJETIVIDADE NOS PROCESSOS DE APRENDIZAGEM", pertencente ao Programa de Pós Graduação da Faculdade de Educação da Universidade de Brasília (PPGE/ FE/UNB). Conduzida pela pesquisadora Polyana Gonçalves de Sousa e orientadora Profa. Dra. Maria Carmen Tacca.

Esta pesquisa tem por objetivo compreender as contribuições da Terapia Ocupacional para o enfrentamento das dificuldades de aprendizagem, considerando as implicações da Teoria da Subjetividade para a prática profissional. Este estudo pretende contribuir com o campo teórico-prático da Terapia Ocupacional no contexto escolar, beneficiando, dentro outros, profissionais e alunos no processo de enfrentamento das dificuldades de aprendizagem.

A pesquisa está em parceria com a professora do e será realizada na escola dos participantes, durante o horário da sala de recursos, ou, caso seja necessário, em outro local e horário, e assim, entraremos em contato para marcar. Os procedimentos realizados serão observação, conversas e alguns instrumentos escritos, de pergunta e resposta e/ou produção livre. Caso seja necessário, a pesquisadora poderá realizar uma gravação de áudio e/ou vídeo para facilitar a transcrição das informações. Portanto, a pesquisa não apresenta risco para a saúde física nem psíquica dos sujeitos participantes. A pesquisa não é remunerada e é isenta de custos financeiros para as crianças/ adolescentes e responsáveis.

A participação de seu filho(a) neste estudo é voluntária e ele/ela terá plena e total liberdade para desistir do estudo a qualquer momento, sem que isso acarrete qualquer prejuízo para ele/ela. As informações relacionadas ao estudo são confidenciais e qualquer informação divulgada em relatório ou publicação será feita sob forma codificada, para que o sigilo seja mantido. A pesquisadora garante que não será divulgado o nome dos participantes. Você e seu filho podem fazer todas perguntas que julgarem necessárias durante e após o estudo.

Desde já, agradeço a colaboração.

Caso você concorde em participar desta pesquisa, assine este documento, que possui duas vias, sendo uma delas sua, e a outra, da pesquisadora responsável.

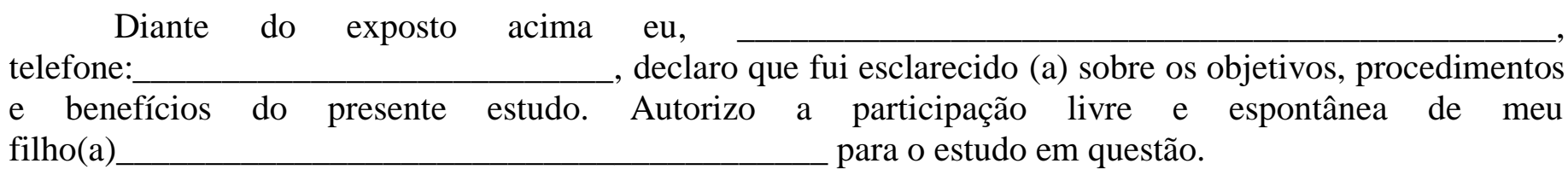

Brasília, __ de de 2016.

Assinatura do responsável

Assinatura da pesquisadora

Qualquer dúvida sobre o estudo ou sobre este ento, pergunte diretamente a pesquisadora Polyana Gonçalves ou entre em contato através do telefone (983138896). 